\title{
A MUNICIPALIZAÇÃO DAS AÇÕES DE SAÚDE DO TRABALHADOR NO SISTEMA ÚNICO DE SAÚDE
}

\author{
RODOLPHO REPULLO JUNIOR
}

Tese apresentada ao

Departamento de Saúde Ambiental da

Faculdade de Saúde Pública da

Universidade de Sāo Paulo

para obtenção do

Título de Doutor em Saúde Pública -

Área de Concentração: Saúde Ambiental

ORIENTADOR:

PROF. JORGE DA ROCHA GOMES

SÃo PAULO

Janeiro de 2.002 
Autorizo, exclusivamente para fins acadêmicos e científicos, a reprodução total ou parcial desta Tese, por processos fotocopiadores.

Assinatura:

Data: 
A todos aqueles que

Lutam contra a violência

Nas ruas,

No campo,

Nos locais de trabalho 
Vejo nosso trabalho, enquanto dirigentes municipais de saúde como uma guerra. Uma guerra contra as conseqüências no campo da saúde, da miséria, da fome, da ignorância, dos ambientes de trabalho insalubres e inseguros, de toda uma forma de organização social violenta, cruel, geradora de desigualdades brutais.

Numa palavra, nós travamos uma guerra em defesa da vida, contra o rastro do sofrimento e morte com o qual o capitalismo brasileiro marca a existência de milhões de pessoas.

David Capistrano da Costa Filho (in memorian) In: Da Saúde e das Cidades São Paulo, Ed. Hucitec. 199.5. p. 37 


\section{AGRADECIMENTOS}

A minha sincera admiração e os meus profundos agradecimentos ao Prof. Jorge da Rocha Gomes, orientador do meu doutorado e deste trabalho, pelos ensinamentos em Saúde do Trabalhador e pelo incentivo permanente.

Aos professores José Carlos Seixas, Luciano A. Prates Junqueira, Paulo Fortes e Maria Silvia Monteiro pelas importantes sugestões que enriqueceram esta Tese;

Aos professores Sérgio Colacioppo e Frida Marina Fischer pelo grande incentivo e apoio ao meu doutorado;

A todos os meus amigos e colegas de Saúde Pública e de Saúde do Trabalhador pelo apoio, pela colaboração e pela salutar convivência;

Aos meus pais, Rodolpho e Eunyce, pela formação pessoal e exemplos de vida;

Às minhas filhas, Talita, Marcelle e Mariana e ao meu neto Kauan, que tenham dias cada vez melhores pela frente;

A Cida, pelo amor, paciência, incentivo ao meu trabalho e dedicação. 


\section{RESUMO}

Repullo Jr R. A municipalização das açōes de saúde do trabalhador no Sistema Único de Saúde. São Paulo; 2.001. [Tese de Doutorado Faculdade de Saúde Pública da USP].

Estudo de caso em que são analisados aspectos envolvidos no campo das ações de saúde do trabalhador, fornecendo subsidios ao gestor municipal do Sistema Único de Saúde para a implantação desse serviço. Foram utilizadas três fontes de informação: pesquisa bibliográfica, entrevistas com atores envolvidos no planejamento e execução dessas ações e visitas aos serviços municipais de saúde do trabalhador de cinco municipios paulistas. A municipalização das ações de saúde do trabalhador vem se estabelecendo, desde a definiçăo do Sistema Único de Saúde na Constituição Federal, sendo que as Normas Operacionais Básicas e a Norma Operacional de Saúde do Trabalhador editadas pelo Ministério da Saúde definem as atribuiçōes e responsabilidades dos municípios nessa área. Propōe-se a organızação da atençăo à saúde dos trabalhadores na rede básica em contraposição à implantação dos Centros de Referência em Saúde do Trabalhador, a capacitação e desenvolvimento dos recursos humanos para a atuação inter e transdisciplinar, o sistema de informação para o planejamento e avaliação das açōes, o arcabouço legal, a concepção e a prática das açōes de vigilancia dos ambientes e processos de trabalho e medidas para a institucionalização e controle social do Programa. Verifica-se que, apesar de Portarias do Ministério da Saúde definirem um repasse diferenciado de recursos para $o$ atendimento ao trabalhador, este não foi implantado fazendo com que esses serviços sejam totalmente custeados por recursos municipais.

Descritores: Saúde do Trabalhador. Municipalização. Programas de Saúde. 


\section{SUMMARY}

Repullo Jr R. A municipalização das ações de saúde do trabalhador no Sistema Único de Saúde [The municipalization of the worker's health actıons on the Unified Health System]. Săo Paulo (BR); 2.001. [Tese de Doutorado Faculdade de Saúde Pública da USP]

Case study that analyzes aspects on worker's health actions field. presenting subsidies to the Unified Health System municipal manager for this service implantation. Were utilized three sources of information: bibliographic research, interviews with the actors envolved on the planning and clecisionmaking of these actions and visits to the worker's health municipal services of five Săo Paulo (Brazil) towns. Worker's health actions municipallizatıon have been occuring in a crescent way, since the definition of the Unified Health System bases on the 1988 Federal Constitution, having the Ministry of Health Basic Operational Norms and Worker's Health Operational Norm delined the municipal accountability. It was proposed the organization of workers health actions at the basic net in contraposition of the implantation of Worker's Health Reference Centers, the human resource formation and development to inter and transdiciplinary actuation, the information system for action planning and assessment, the concept, practice and law that enforce the surveillance of workplaces and ways to Program institutionalization and social control It was verified that, though Ministry of Health rules define a different resource repass to worker attention, it was not implanted, and the worker 's heaith services are totally financed with municipal resources.

Descriptors: Worker's health. Municipalization. Health programs 


\section{INDICE}

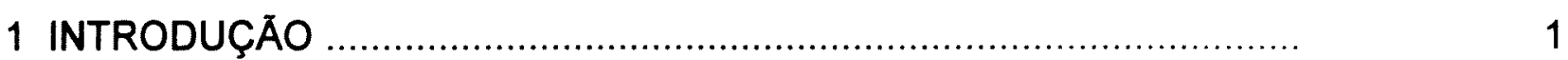





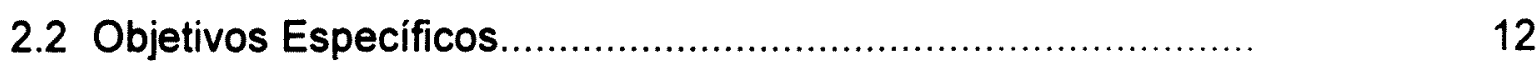

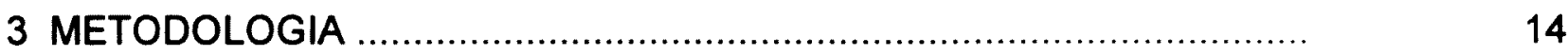



4.1 A municipalização das ações de saúde no Brasil....................... 16

4.2 Formulação de uma política municipal de saúde do trabalhador . 30

4.3 Organização de serviços de saúde do trabalhador no municipio ..... 36

4.4 Recursos Humanos - a inter e a transdisciplinaridade ....................... 50

4.5 Recursos Humanos - Capacitação e desenvolvimento de pesscial..... 58

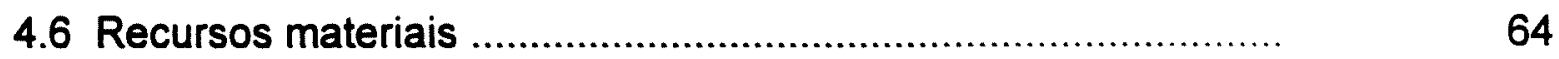

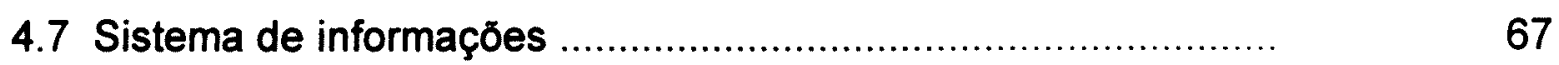

4.8 Vigilância dos ambientes e processos de trabalho -

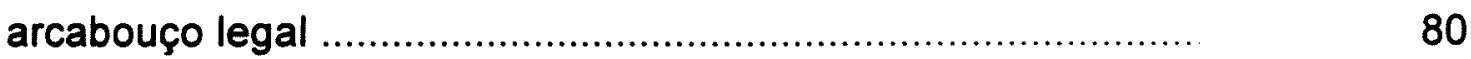

4.9 Vigilância dos ambientes e processos de trabalho -



4.10 Financiamento das ações de saúde do trabalhador no município... 101

4.11 Institucionalização dos programas de saúde do trabalhador ... 105

4.12 Participação popular em saúde do trabalhador .................... 108

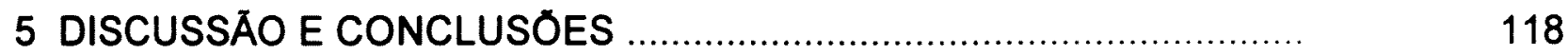

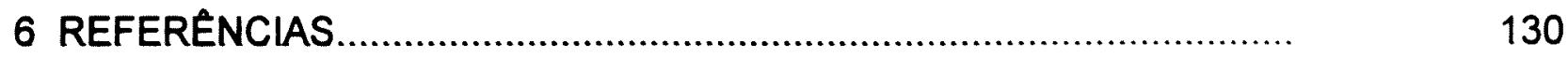

ANEXO I - Termo de consentimento

ANEXO II - Instrução normativa de vigilância à saúde do trabalhador

ANEXO III - Norma Operacional de Saúde do Trabalhador no SUS

ANEXO IV - Manual para a Implantação de um Programa Municipal de Saúde do Trabalhador 


\section{INTRODUÇÃO}

A descentralização com direção única em cada nível de governo é uma das diretrizes do Sistema Único de Saúde - SUS, em implantação no Brasil desde a promulgação da Constituição Federal (BRASIL, 1988) Nesse processo, vem sendo transferida aos municípios a responsabilidade pela execução de ações que antes faziam parte das atribuições dos outro:s niveis de governo ou até mesmo de outros setores do Poder Executivo, como a Saúde do Trabalhador.

MOTTA (1994) define que a descentralização, na perspectiva administrativa, é toda transferência de poder, autoridade e responsabilidade, antes restritos a instâncias superiores.

BOSSERT (1998), estudando sistemas de saúde de paises em desenvolvimento, afirma que a descentralização è um dos principios requeridos para a implementação de sistemas de saúde nessas localidades. Propõe uma estrutura de análise que pode ser usada para desenhar e avaliar a descentralização de sistemas de saúde, começandı pela presunção de que a descentralização não é um fim em si mesmo, mas que deve ser desenhada e avaliada pela sua capacidade de atingir amplos objetivos de reforma sanitária: equidade, eficiência, qualidade e saúde financeira.

Entre os princípios do SUS, respaldados pela Constituição Federal de 1988, inscreve-se a descentralização, expressa claramente pela transferência de serviços para os municipios, onde está prevista a conjugação de recursos da União, estados e municipios para a garantia da assistência à saúde da população. A partir dessas legislações não deverá 
se falar em "convênios" ou "acordo de vontades", pois é competência das três esferas cuidar da saúde da população (RINALDI e cols. 1997).

Segundo ATKINSON e cols. (2.000), a administração descentralizada da atenção à saúde é uma estratégia chave para a reestruturação de sistemas de saúde em todo o mundo. E prosseguem, afirmando que embora algumas exceções tenham sido notadas, a descentralização é nia maior parte das vezes apresentada e aceita como a forma de agir de dilerentes cores do espectro político. No entanto, avaliam que poucos estudos têm sido realizados para verificar até que ponto as promessias da descentralização se transformam em realidade.

Na literatura pesquisada, aparecem tipologias distintas de graus ou formas de descentralização, tornando-se bastante trabalhosa e, no caso, desnecessária, qualquer tentativa de descrever a ampla gama de siłuaçōes e variações de definições encontradas. Pelo estudo abrangente reaalizado sobre o tema em sua tese de doutorado e pela série de trabalhos publicados sobre o assunto, adota-se a conceituação oferecida por JUNQUEIRA (1996, 1997 a, b, c, 1998).

O Autor (JUNQUEIRA 1997 c) afirma que a centralizaçiäo e a descentralização possuem uma relação dialética:

"Se o conceito de descentralização, nos paises latinoamericanos, remete à democratização e à participação, o seu entendimento, no entanto, passa necessariamente, pela centralização. Um poder totalmente descentralizado com a extinção do poder central constitui a negação do Estado. A descentralização deve supor sempre a possibilidade de o Estado recuperar D poder transferido. 
Por isso descentralização e centralização são dois extremos opostos, mas não mutuamente excludentes, ligados entre si por uma relação dialética. Ambos subsistem integralmente, embora possam manifestar-se sob diferentes formas, o que explica que nãc) exista descentralização nem centralização em estado puro.

Estando os dois extremos relacionados dialeticamente, a existência de um não implica o desaparecimento do outro. Entender a descentralização como processo que se dá em determinado tempo e espaço implica, assim, entendê-la em relação (dialética) com a centralização. Se a descentralização é definida como procésso de transferência de poder do centro para a periferia, só c poder centralizado pode ser descentralizado; não existindo poder central, não haverá o que transferir."

Para o Autor, descentralização difere de desconcentração, podendo esta se constituir como parte do processo de descentralização, não etapa ou um caminho para se chegar a ela. Desconcentrar é delegar competências sem deslocar o poder de decisão. Nesse caso, o órģão que transfere competências não perde seu poder de decisão e o que recebe as tem por delegação, agindo em nome do governo central, sua autonomia relativa. Nesse sentido, a desconcentração não conduz, necessariamente, à descentralização, constituindo-se em um outro movimento.

Ainda segundo 0 Autor, a desconcentração difere da descentralização, pois enquanto na primeira há apenas um deslocamento da decisão, na segunda o poder é transferido.

JUNQUEIRA (1997) ainda trabalha o conceito de devolução sıcial 
"A descentralização envolve mudanças, um novo processo de articulação entre Estado e Sociedade, entre o poder público e a realidade social. Apesar da importância da atuação do Estado, ele não pode substituir a sociedade em qualquer que seja o sistema. Assim, é necessário saber o que transferir, para quem $€$ como transferir. Mesmo que a descentralização ocorra no âmbito do Estado, este pode transferir para outro ente público a prestação de serviços que é da sua competência. $E$ isso significa devolução social."

O Autor assinala que a devolução é uma alternativa para a gestão das políticas sociais e ressalta que transferir poder de gestão prara os usuários dos serviços, desde que sob o controle do Estado, não é privatização.

"A privatização poderá ocorrer no que ser refere às funçōes quase-públicas ${ }^{1}$ e não de maneira indiscriminada em todo o sistema estatal. Ao contrário, a descentralização não deve se realizar de maneira uniforme em todo o aparato estatal. Seu reordenamento deve obedecer às diferenças de funções, pois a lógica não é apenas da redução do gasto, mas de tornar o Estado mais ágil e eficaz para atender o cidadão, daí a necessidade de liberá-lo das funções quasepúblicas."

É de se assinalar que para alguns autores, como MENDES (1998), a privatização é uma das formas de descentralização. Não se pode corıcordar

\footnotetext{
1 "Quase públicas" ou "meritórias" são os bens e serviços colocados entre os dois extremos, ou seja, o puramente estatal e o privado-mercantil. O que os distingue dos bens e serviços privados é o princípio da exclusão, ou seja, aos privados só se tem acesso mediante pagamento, enquanto os "quase públicos" ou "meritórios" são de interesse público e, portanto, de responsabilidade do " tado, que intervém para fins de regulação social ativa.
} 
com essa conceituação, pois na descentralização, quem recebe as competências estará sujeito às normas, à avaliação e controle estabelecidos pelo ente cedente. Na privatização, há uma passagem integral do tem para a iniciativa privada, que passa a ter controle total sobre ele, cessando a responsabilidade do Estado sobre esse bem ou serviço. Assim, apesar de a privatização constituir no discurso neoliberal um dos objetivos da descentralização, conceitualmente não o é (JUNQUEIRA, 1997).

HORTALE (1997), analisando a descentralização das ações de saúde em diversos paises, verificou que a ela, nas organizaçōes públicas, fazendo parte do processo de construção do Estado democráticcı, esteve presente durante as últimas décadas na agenda política de setores hegemônicos e contra-hegemônicos da sociedade. Essa proposta, cada vez mais freqüente nas reformas dos sistemas de saúde, vinha serido vista como uma solução. As maneiras pelas quais ela foi implementada variaram em função, quer das características e peculiaridades de cada país, quer das interpretações diferenciadas acerca do seu significado.

SOLORZANO (1997) analisando o financiamento das ações de saúde no Canadá, onde o gasto do setor público em saúde provém basicamente dos impostos e é compartido entre o governo provincial - $61 \%$ e o federal - $37 \%$-, sendo que os governos locais e os fundos de compensação dos trabalhadores compartem os $2 \%$ restantes, conclui que para evitar uma deterioração progressiva da acessibilidade e qualidade da atenção e prevenir maiores incrementos dos custos, foram propostias várias reformas, entre elas a descentralização das responsabilidades.

WUNSCH (2001) afirma que os estados africanos, desde o início dos anos 80 , despenderam muita retórica e, em alguns casos, recursos substanciais na descentralização política e administrativa. 
Para RODRIGUEZ NETO (1997), a descentralização faz parte. juntamente com a participação, de um binômio indissociável que coınpōe a essência da questão democrática no SUS. A descentralização tem que ser compreendida como uma diretriz eminentemente política que, evidentemente, tem também conseqüências administrativas; mas a idéia è que o poder de decisão seja exercido pelos seus reais atores, o mais próximo possivel de onde ocorrem os fatos, da realidade. Dessa forma, pode-se conferir pertinência e relevância a essas decisões, na suposição de que elas interessam ao conjunto dos sujeitos das mesmas e, assim, são "positivas" no sentido em que contribuem para o alcance das aspiraçōes comuns, de interesse coletivo.

No mesmo sentido, vinculando a descentralização à maior possibilidade de participação, JUNQUEIRA (1997 b) afirma que este procedimento administrativo constitui um fator importante para estimular a dinâmica participativa mediante a abertura de canais de comunicação entre os usuários e as organizaçōes descentralizadas, permitindo, no minirno, que façam chegar suas necessidades a quem tem o poder de decidir. $O$ ente descentralizado possibilita aos sujeitos sociais a participação no processo de elaboração, decisão e execução de programas e normas.

Na dimensão política, como consideram HORTALE e cols. (2000), a descentralização não é um valor e um fim em si mesma, mas uma condição necessária para melhorar o acesso, a adequação da resposta social, a participação, a qualidade, a sustentação e a eqüidade no campo da saúde. Os autores consideram que um sistema de saúde descentralizado, em uma dinâmica de transferência de recursos e autoridades às diferentes instâncias do sistema de saúde, causa um impacto positivo na gestão e nas diferentes modalidades de atenção e dá oportunidade para que os processos de reforma permitam a geração e desenho de novos mocelos de atenção, papéis e funções, modalidades de capacitação, sistema de 
remuneração e novas formas de participação das instituições, sindicatos e setores acadêmicos.

ELIAS (1996) afirma que o objetivo da descentralização è o fortalecimento da esfera local, o que demanda deste capacitação de várias ordens para que possa arcar com aquelas transferências sem que isto implique em perdas de capacidade de resposta às necessidades sociais. Desta ótica, a descentralização exige pré-requisitos do nível local para sua efetivação; e mais, mesmo na inexistência destas, a esfera central encontrase comprometida com a local, no sentido do provimento do auxilio necessário para a obtenção desses requisitos.

REY DEL CASTILLO (1998), ao avaliar o processo de descentralização sanitária ocorrido na Espanha, afirma que este coritribuiu ao reforço de uma valoração fundamentalmente econômica da saúde, e como conseqüência, a uma maior "expropriação" das decisōes sanitárias, que passaram a ser objeto de uma atenção e decisão maiores por parte das áreas económicas dos governos, tanto no nivel central como nos descentralizados. As razōes para isso são duplas: a impotância proporcional do gasto sanitário nos orçamentos das Comunidades Autônomas, que recebem os repasses financeiros das outras esferas de governo - a parte sanitária deve rondar os $30 \%$ do orçamento autonćmico a desconfiança - tanto central, como das áreas econômicas dos governos autonômicos - até o controle do gasto sanitário - em um contexto geral de controle do gasto público - num marco descentralizado.

HEALY e MCKEE (1997), estudando a reforma do setor saúite nos paises da Europa Central e do Leste, verificaram que muitos sistemas dessas localidades foram devolvidos e descentralizados para o setor público regional e local, bem como para empresas autônomas; "não lucrativas". 
URIBE RIVERA (1996) afirma que três principios de organização do Planejamento Estratégico Situacional podem ajudar na tarefa de precisar as diretrizes e características de um sistema de gerência descentralizado voltado para o desenvolvimento de uma organização comunicante: o princípio da responsabilidade, o princípio da descentralização e o princípic da subordinação das formas organizativas às práticas de trabalho e destas às estruturas mentais. O princípio da descentralização, citando MATUS (1994), reza o seguinte:

"Nenhum problema quase estruturado deve ser processado em um nivel em que receba um tratamento rotineiro, todo problema deve ser processado criativamente. Se um problema recebe urn trato rotineiro porque tem baixo valor nesse nivel, deve descender na estrutura macro-organizativa até o nível descentralizado em que tenha alto valor e possa ser tratado criativamente. Todo problema deve ser enfrentado naquele nivel em que tem alto valor. Cada nivel hierárquico organizativo deve ter governabilidade sobre os problemas de alto valor que 0 afetam, salvo no caso dos problemas que podem dissolver-se de forma eficaz em um espaço maior. Todo problema bem estruturado deve descentralizar-se mediante normatizaçãci".

Para a Organização Mundial da Saúde (WHO, 2000), em muitos países latino-americanos, incluindo Argentina e Brasil, a descentralizaçāo levou a uma mudança no processo de decisão e vem devolvendo direitos e responsabilidades do nivel central para outros niveis de governo.

WUNSCH (2001), no entanto, baseando-se em estudo realizado em países africanos, verifica que muitos atores centrais não têm comproınissos sérios com a descentralização, a ela interpondo vários obstáculos. [leixam brechas na legislação, não provêm recursos nos orçamentos, deixam de 
treinar o pessoal local ou encontram qualquer outra forma de retomar o controle para a esfera central, processo este que o Autor denonina de 'recentralização'.

Entre as responsabilidades que vêm sendo transferidas aos municipios, encontram-se as ações de saúde do trabalhador, incluídas entre as atribuições do SUS no artigo $6^{\circ}$ da Lei Orgânica da Saúde - LOS (BRASIL, 1990). Nesse dispositivo legal, a saúde do trabalhador está definida como um conjunto de atividades que se destina, através da:s açōes de vigilância epidemiológica e vigilância sanitária, à promoção e proteção da saúde dos trabalhadores, assim como visa à recuperação e reakilitação da saúde dos trabalhadores submetidos aos riscos e agravos advindos das condiçōes de trabalho, abrangendo:

I - assistência ao trabalhador vítima de acidente do trabalho ou portador de doença profissional e do trabalho;

II - participação, no âmbito da competência do SUS, em estudos, pesquisas, avaliação e controle dos riscos e agravos potenciais à saúde existentes no processo de trabalho;

III - participação, no âmbito de competência do SUS, da normatização, fiscalização e controle das condições de produção, extração, armazenamento, transporte, distribuição e manuseio de substâncias, de produtos, de máquinas e de equipamentos que apresentam riscos à saúde do trabalhador;

IV - avaliação do impacto que as tecnologias provocam à saúde;

V - informação ao trabalhador e à sua respectiva entidade sindical e às empresas sobre os riscos de acidente do trabalho, doença profissiorial e do 
trabalho, bem como os resultados de fiscalizações, avaliaçōes ambientais e exames de saúde, de admissão, periódicos e de demissão, respeitados os preceitos da ética profissional;

VI - participação na normatização, fiscalização e controle dos serviços de saúde do trabalhador nas instituições e empresas públicas e privada:s;

VII - revisão periódica da listagem oficial de doenças originadas no processo de trabalho, tendo na sua elaboração a colaboração das eritidades sindicais; e

VIII - a garantia ao sindicato dos trabalhadores de requerer ao órgão competente a interdição de máquina, de setor de serviço ou de todo o ambiente de trabalho, quando houver exposição a risco iminente para a vida ou saúde dos trabalhadores.

Como observam CARVALHO \& SANTOS (1992), o conteúdo da expressão 'saúde do trabalhador', como está na Constituição e na LOS, é mais amplo que o das expressões 'inspeção do trabalho' e 'segurança e medicina do trabalho' que estăo na Consolidação das Leis do Trabalho CLT. As ações referentes à saúde do trabalhador que se encontravam na alçada do Ministério do Trabalho e Previdência Social passaram a integrar o SUS, sendo que a legislação infraconstitucional anterior, que po ventura esteja em conflito com a Constituição de 1988, năo deve subsistir, seja por inconstitucionalidade superveniente ou por revogação.

Segundo DALLARI (1995), a saúde do trabalhador foi, indubitavelmente, um destaque no debate constituinte nacional e $\epsilon$ stadual. Considerada de grande importância para a formalização do novo equilibrio que se estabelecia entre 0 capital e 0 trabalho, os sindicatos de trabalhadores, julgaram que haviam sido vencidos na disputa pela 
expressão desse direito na esfera federal e assim, procuraram pressionar os constituintes estaduais. Isso porque se confundiu, inadequadamente, a inspeção do trabalho, reservada à União, com a vigilância da saúde dos trabalhadores, obrigação do sistema de saúde que, por mandamento constitucional, deve ser descentralizado para todas as esferas de governo.

Frente à complexidade da Saúde do Trabalhador e a novidade da sua inclusão entre as atribuições do SUS, com uma grande parcela dessa responsabilidade para a esfera municipal, fica o gestor local com incertezas e dificuldades para a implantação dessas ações.

Desta forma, no campo da Saúde Pública, justifica-se a necessidade de estudo do assunto, revisando-se a literatura acadêmica e aprofundandose o conhecimento do tema. Também, a verificação, análise e divulgação das práticas adotadas pelos serviços municipais de Saúde do Trabalhador existentes contribuirá para a disseminação da sua implantação, em pról da melhoria da qualidade de vida da população e para o aperfeiçoamento do Sistema Único de Saúde. 


\section{OBJETIVOS}

\subsection{Objetivo Geral}

Analisar os aspectos envolvidos no campo das ações de saúde do trabalhador, buscando fornecer subsídios ao gestor municipal do SUS para a implantação desse serviço.

\subsection{Objetivos Específicos}

1. Propor formas de organização dos serviços municipais de saúde para a prestação de ações de saúde do trabalhador, considerando rede física, hierarquização dos serviços e recursos materiais, como também a necessidade, capacitação, desenvolvimento e aprimoramento de recursos humanos;

2. Estudar o arcabouço legal e as concepções e práticas existentes em municipios para a execução de ações de vigilância dos ambientes e processos de trabalho;

3. Analisar os sistemas de informação em Saúde do Trabalhador e a forma de sua utilização pelos municípios para o planejamento, execução e avaliação das ações;

4. Analisar as formas de financiamento das ações municipais de saúde do trabalhador;

5. Analisar os aspectos do controle social em saúde do trabalhador no âmbito municipal do SUS; 
6. Elaborar um Manual para a Implantação de Ações em Saúde do Trabalhador no Município, destinado ao gestor do SUS Municipal. 


\section{METODOLOGIA}

Pelas características e natureza do objeto estudado, será adotada metodologia qualitativa de pesquisa, realizando-se um estudo de caso (STAKE, 1994).

Foi realizada uma revisão bibliográfica exaustiva do tema, de literatura científica nacional e internacional, buscando conhecer reflexões realizadas e relatos de experiências de implantação de ações de saúde do trabalhador no âmbito municipal ou equivalente.

Foram também realizadas entrevistas semi-estruturadas com gestores de saúde e gerentes de serviços de saúde do trabalhador de municípios do Estado de Săo Paulo. Nessas entrevistas, pretendeu-se conhecer as experiências de implantação dos serviços, dificuldades e facilidades encontradas, bem como o impacto dessas ações no processo saúde-doença no trabalho. As entrevistas foram gravadas e o conteúdo foi transcrito para posterior análise.

A entrevista é definida como um processo de interação entre duas pessoas na qual uma delas, o entrevistador, tem por objetivo a obtenção de informações por parte de outro, o entrevistado (HAGUETTE, 1995). As informaçōes serão obtidas através de um roteiro de entrevista onde constará uma lista de pontos previamente estabelecidos, de acordo com o que se espera obter de dados do entrevistado. Para cada entrevistado haverá um roteiro diferente preparado de acordo com a natureza da contribuição que o serviço tem a oferecer para o estudo. 
Cada pessoa entrevistada tomou ciência do objetivo da pesquisa e da forma como deveria ser usada a informação transmitida através do Termo de Consentimento Pós-Informação (Anexo I).

Os entrevistados foram cinco coordenadores de Programas Municipais de Saúde do Trabalhador e dois gestores locais de saúde. 0 menor município estudado possui cerca de 170.000 habitantes, outros dois em torno de 350.000 habitantes cada, outro com um milhão de pessoas e 0 maior com aproximadamente 10 milhões de moradores.

Foram também realizadas visitas aos serviços públicos de atenção à saúde do trabalhador desses municipios buscando-se conhecer detalhes técnicos operacionais, como também diferentes concepções e práticas de intervenção no processo saúde-doença no trabalho,.

Dentre todos os municípios que desenvolvem ações de Saúde do Trabalhador no Estado de São Paulo, foram estes os escolhidos, para que o conjunto tivesse componentes de diferentes tamanhos de populacão, fossem contemplados o Interior, a Região Metropolitana e a Capital e para que fizessem parte do estudo diferentes concepções e práticas em Saúde do Trabalhador, segundo a vivência do Autor como profissional da área e o seu prévio conhecimento sobre 0 assunto.

As informaçōes colhidas e propostas desenvolvidas foram também utilizadas para a elaboração do Manual que se encontra no Anexo 4 desta Tese, a ser utilizado pelo gestor do SUS que tenha por objetivo implantar ações em Saúde do Trabalhador no Município. Esse Manual contém, além dos aspectos conceituais sobre o tema, informaçōes sobre legislação, financiamento, organizaçăo da rede física de atendimento, recursos humanos necessários e seu treinamento e desenvolvimento para a implementação das ações. 


\section{4 . REsultados}

\subsection{A Municipalização das Ações de Saúde no Brasil}

O Município foi introduzido no Brasil no princípio do regime colonial, com base nas Ordenações Filipinas, que transformaram os conselhos em câmaras compostas por vereadores, com funções administrativas, pelo procurador, espécie de advogado do município, pelos almotacés, com funções executivas subalternas, e pelos juizes ordinários, com jurisdição civel e criminal (LORDELLO DE MELLO, 2001).

Os municípios foram bastante fortalecidos em vários aspectos, pela Constituição de 1988, alcançando uma posição única entre os países em desenvolvimento, fazendo parte da Federação, junto com os estados e o Distrito Federal.

DALLARI (1992) encontra muitos pontos favoráveis para os municípios na organização constitucional brasileira e assim se expressa sobre 0 assunto:

"No Brasil, mantivemos a organização federativa introduzida pela primeira Constituição Republicana em 1.891, baseada na organização dos Estados Unidos da América. Sem dúvida, já no início da nossa organização institucional se observou que 0 federalismo brasileiro é distinto do norte-americano. $\mathrm{Na}$ federação brasileira há uma distribuiçăo de competências em três niveis. Quando um teórico norte-americano fala de governo local em seu direito constitucional, está se referindo aos governos dos Estados da União, por exemplo, a Califórnia ou Nova York. Porém, quando um teórico brasileiro fala de governo local em nossos termos constitucionais, refere-se ao governo municipal pois no sistema 
constitucional brasileiro a própria Constituição da República distribui as competências e essa distribuição se faz em três niveis de governo, garantindo a autonomia aos estados e aos municípios. Neste sentido, uma inovação da Constituição de 1.988 é a que incorpora um capítulo relativo às 'competências comuns', expressão utilizada no seu texto. Nós temos competências que são exclusivas da União, dos estados e dos municípios, mas também que são comuns à União, aos estados e aos municípios. Entre essas 'competências comuns' está exatamente a relativa aos assuntos da saúde."

As origens do processo de municipalização da saúde no Brasil remontam aos anos 50 quando, de modo embrionário, surgia no interior do sanitarismo desenvolvimentista essa concepção de organização do sistema. (HEIMANN, 2.000). Na década seguinte, no governo João Goulart, confirmando a força dessa idéia, o Ministro da Saúde Wilson Fadul apresentava na $3^{a}$. Conferência Nacional de Saúde, realizada em dezembro de 1963, uma proposta de municipalização dos serviços de saúde. O núcleo do projeto era, segundo o Ministro, criar uma rede flexivel que em nivel municipal se adequasse à realidade do Município e que fosse se tornando mais complexa à medida que o próprio Município se desenvolvesse.

O golpe de 64 e a instauração do regime militar impuseram um corte nesse ânimo descentralizante, desdobrando-se em um período que favoreceu experiências centralizadoras e privatizantes. Predominou, a partir dai, um modelo de gestão da saúde centrado, sob aspectos financeiros e operacionais, no governo federal, cujo arranjo institucional culminou com a criação do Instituto Nacional de Assistência Médica da Previdência Social INAMPS - em 1977.

Ainda, segundo HEIMANN (2.000), até a primeira metade da década de 70 , o desenvolvimento das açőes e serviços no âmbito local ficou 
praticamente restrito às experiências dos programas comunitários de saúde, no modelo da Medicina Comunitária. A atenção à saúde despendida pelo INAMPS privilegiava o atendimento clínico individual e a atenção hospitalar e especializada, sendo que as ações de promoção e proteção da saúde eram executadas por serviços governamentais não ligados à Previdência Social, com recursos extremamente reduzidos.

Apesar da hegemonia desse modelo, uma das iniciativas adotadas no sentido da descentralização foi o Programa de Interiorização das Açōes de Saúde e Saneamento - PIASS - criado em 1976 com a finalidade de prover estrutura básica de saúde para pequenas comunidades, principalmente da região Nordeste. Outra iniciativa foi a tentativa de criação do Programa Nacional de Serviços Básicos de Saúde (Prev-Saúde) em 1980, que não se concretizou por resistências do setor privado e da tecno-burocracia do INAMPS.

A crise financeira da Previdência levou o governo a criar em 1981 o Conselho Consultivo da Administração da Saúde Previdenciária - Conasp - qual formulou o Plano de Reorganização da Assistência à Saúde no Âmbito da Previdência Social, que por sua vez instituiu o Programa das Ações Integradas de Saúde - AIS - tido como a primeira ação de grandes proporções rumo ao aperfeiçoamento do sistema de saúde.

As AIS se desenvolviam da seguinte forma: eram assinados convênios entre os niveis de governo para repasse de verbas, formulados planos de saúde e instaladas Comissões Interinstitucionais de Saúde nos âmbitos estadual, regional, municipal e local. Mediante as AIS logrou-se, no periodo de 1984 a 1987, tornar exequivel a expansão da capacidade instalada da rede pública, particularmente ambulatorial, além de ser alcançado o maior nivel de articulação interinstitucional até então. Cerca de 2.500 municipios se incorporaram a este processo e foram beneficiados 
com recursos aplicados nas secretarias municipais de saúde (HEIMANN, 2.000).

O movimento de Reforma Sanitária, implementado pelos profissionais e usuários dos serviços de saúde visando a formulação de propostas de organização institucional do setor, atingiu seu ponto alto na VIII Conferência Nacional de Saúde, em 1986, que reuniu cerca de 5.000 delegados, metade dos quais representando a sociedade civil, os quais deliberaram pela criação do Sistema Único de Saúde universal, igualitário, com participação popular, integral e descentralizado (MINISTÉRIO DA SAÚDE, 1987)

Durante os trabalhos da Assembléia Nacional Constituinte, em 1987, - Ministério da Previdência e Assistência Social formulou a proposta do Sistema Unificado e Descentralizado de Saúde - SUDS, o qual representou um dos maiores avanços no processo de descentralização da saúde, principalmente no Estado de São Paulo.

Sobre o SUDS, JUNQUEIRA (1996) afirma que foi conformado no âmbito da Reforma Sanitária e narra que:

"Enquanto as propostas da Reforma eram encaminhadas na Constituinte, o grupo dirigente do INAMPS, com o respaldo da direção do Ministério da Previdência e Assistência Social, procurou operacionalizar mudanças que permitissem redefinir o modelo de saúde hegemônico no país.

A VIII Conferência Nacional de Saúde preconizara a incorporação do INAMPS pelo Ministério da Saúde. Isso estava em discussão na proposta do SUS na Constituinte. Enquanto essa proposta era encaminhada ao Congresso, os dirigentes preocuparam-se com a reformulação das AIS, para transitar para um 
novo sistema. O SUDS, com o aprofundamento das AIS, pretendia viabilizar a reorganização do setor, no sentido da Reforma Sanitária, de modo a superar a situação de centralização e desordenação.

As Superintendências Regionais do INAMPS tiveram suas funções transferidas para as secretarias de estado da saúde, as quais, junto às secretarias municipais de saúde, poderiam passar a exercer papel decisivo e de comando na nova política nacional de saúde. Isto significava que as secretarias da saúde, que até então lidavam com as ações preventivas, incorporariam a assistência médica e os recursos dela advindos. Com isso, elas poderiam passar não só a desempenhar novas funções, mas também desfrutar de novo prestígio no âmbito do governo estadual."

O Programa SUDS acelerou a unificação do sistema de saúde, não só dos serviços próprios, mas também da rede contratada e a transformação do INAMPS.

A Constituição Federal de 1988, a LOS e a Lei 8.142/90 (BRASIL, 1990 b) consolidaram as bases legais da descentralização no SUS e a partir desse periodo foram incentivadas as experiências de gestão local, com repasses de recursos para os municipios incrementarem as ações de saúde.

Seja por força da pressão de grupos organizados da sociedade, interessados na efetivação do pleno direito à saúde, seja pela atuação de profissionais envolvidos na implantação de um sistema de saúde público e de qualidade, ou pela ação de parlamentares e governantes voltados para o atendimento das demandas sociais da população, a descentralização vem sendo implantada no âmbito do SUS, apesar da cultura institucional brasileira agir no sentido inverso. 
COHN (2.001) avalia que o processo de descentralização em prática no Brasil não quebrou com a lógica de o governo central manter totalmente o controle e as rédeas do repasse de recursos, seja em termos da definição das modalidades através das quais eles são repassados. $\mathrm{Na}$ interpretação da Autora, configura-se mais um processo de desconcentração da execução das ações de saúde do que de efetiva descentralização, a qual deveria se dar com a plena autonomia dos estados e municipios na definição, implementação e controle de suas respectivas políticas de saúde, o que na realidade não acontece. As sucessivas edições de normas operacionais básicas evidenciam uma recorrente e crescente normatização desse processo de delegação tutorada de tarefas e responsabilidades às esferas subnacionais de governo sob tutela estrita do nivel central.

As Normas Operacionais Básicas - NOB - editadas pelo Ministério da Saúde em 1991, 1993 e 1996 são os instrumentos técnicos que têm orientado esse mecanismo de redefinição institucional dos papéis dos níveis de governo federal, estadual e municipal no tocante à oferta de serviços de saúde.

A NOB $01 / 91$ transformou os serviços de natureza pública, tanto estaduais como municipais, em prestadores a serem ressarcidos conforme a sua produção, igualando-os aos de natureza privada e filantrópica. Introduziu também o relacionamento direto entre o Ministério da Saúde e as secretarias municipais de saúde, por meio dos "convênios de municipalização", estimulando o cumprimento dos requisitos -fundos e conselhos municipais de saúde - previstos para o repasse de recursos financeiros segundo a Lei $8.142 / 90$ e que, em fins de 1992, já haviam sido efetivados em quase 2.000 municipios (HEIMANN, 2.000). 
A NOB 01/93 (MINISTÉRIO DA SAÚDE, 1993) teve sua redação baseada no documento "Descentralização das ações e serviços de saúde: a ousadia de cumprir e fazer cumprir a Lei" aprovado pelo CONSELHO NACIONAL DE SAÚDE (1993) o qual analisou os dispositivos legais de regulamentação do SUS e precisou as competências das três esferas de governo. Para os municípios, cabe a formulação de políticas de âmbito local, o planejamento, execução, avaliação e controle das ações e serviços de saúde, quer sejam voltadas aos individuos, ao coletivo ou ao ambiente, inclusive educação para a saúde e processos de produção, distribuição e consumo de produtos de interesse para a saúde.

A NOB 01/93 estabeleceu que o processo de descentralização fosse feito através de diferentes sistemáticas de relacionamento entre a esfera federal e as outras duas esferas político-administrativas, propiciando a convivência de situações diferenciadas no que se refere às condições de gestão do SUS nos estados e municípios. As sistemáticas adotadas para os municípios foram a gestão incipiente, a gestão parcial e a gestão semiplena.

O municipio em gestão incipiente tinha como responsabilidade, assumir a contratação e autorização do cadastramento de prestadores, programar e autorizar a utilização de Autorizações de Internação Hospitalar e procedimentos ambulatoriais, controlar e avaliar os serviços ambulatoriais e hospitalares públicos e privados e demonstrar disposição e condição de assumir o gerenciamento das unidades ambulatoriais públicas existentes no municipio. Além disso, devia incorporar à rede de serviços ações básicas de saúde, nutrição, educação, vigilância epidemiológica e sanitária e desenvolver ações de vigilância de ambientes e processos de trabalho e de assistência e reabilitação do acidentado do trabalho e do portador de doença ocupacional. 
Em gestão parcial, o municipio devia executar todas as ações de responsabilidade do município em gestão incipiente e também assumir o gerenciamento das unidades ambulatoriais públicas existentes no município.

O municipio que assumisse a gestão semi-plena deveria executar todas as ações listadas anteriormente, assumindo também toda a prestação de serviços ambulatoriais e hospitalares, nela incluido o pagamento dos prestadores privados. Em cada uma das formas de gestão havia maneiras diferentes de repasse de recursos financeiros do nível federal para o municipal

A mudança promovida, a partir de 1993, no cenário do processo de municipalização buscou recuperar os principios constitucionais, resgatando a relação de parceria (JUNQUEIRA, 1997 a). Isso, contudo, não pareceu sensibilizar parcela significativa dos municipios e nem dos estados. A maioria dos municipios, preocupados com os gastos decorrentes da incorporaçăo dos equipamentos públicos, não se dispôs a correr novos riscos, arcando com a gestão do sistema local de saúde. A adesão a esse novo processo de descentralização não foi fácil, e as respostas variaram em razão das diferenças, explicitadas na comparação dos dados de ingresso dos municípios em cada um dos estágios da municipalização, em outubro de 1994 e em setembro de 1995.

No Estado de São Paulo, em outubro de 1994, a forma de gestão semiplena havia sido pleiteada por oito municípios: Diadema, São José dos Campos, Santos, São Vicente, Sertãozinho, Votorantim, Assis e Mauá. Até setembro de 1995, a gestão semiplena foi incorporada por apenas mais 4 municipios: Itu, Jundiaí, São Bernardo do Campo e São Caetano do Sul, perfazendo um total de doze municipios. 
Muito embora tenha representado um grande avanço para o processo de descentralização, a NOB/93 continha imperfeições e imprecisões que alimentaram a discussão e a busca por aprimoramentos. Uma das falhas detectadas era a pouca ou nenhuma ênfase no papel dos estados, pois a descentralização privilegiava fundamentalmente as relações entre a União, por meio do Ministério da Saúde, e os municípios. Essa falha poderia fragmentar o sistema e comprometer sua unicidade. No entanto, cabe ressaltar que se estavam criando formas práticas de descentralizar, sendo que as formas encontradas posteriormente tiveram ai sua base (MINISTÉRIO DA SAÚDE, 2000 b).

As discussões nos fóruns da saúde prosseguiram, inclusive durante a X Conferência Nacional de Saúde, realizada em setembro de 1996, e os entendimentos alcançados, principalmente na Comissão Intergestores Tripartite e no Conselho Nacional de Saúde, desembocaram no que veio a ser a nova NOB, editada em novembro de 1996, sendo que suas determinações só vieram a ser implantadas no início de 1998.

A NOB 01/96 (MINISTÉRIO DA SAÚDE, 1996) definiu que a totalidade das açōes e de serviços de atenção à saúde, no âmbito do SUS, deve ser desenvolvida em um conjunto de estabelecimentos, organizados em rede regionalizada e hierarquizada, e disciplinados segundo subsistemas, um para cada municipio - o SUS Municipal - voltado ao atendimento integral de sua própria população e inserido de forma indissociável no SUS, em suas abrangências estadual e nacional.

A partir da NOB 01/96, os municípios podem habilitar-se em duas condições:
a) GESTÃO PLENA DA ATENÇĀO BÁSICA e
b) GESTÃO PLENA DO SISTEMA MUNICIPAL. 
As responsabilidades do Município em Gestão Plena da Atenção Básica são:

a) Elaboração de programação municipal dos serviços básicos e da proposta de referência ambulatorial especializada e hospitalar para seus munícipes;

b) Gerência de unidades ambulatoriais próprias;

c) Gerência de unidades ambulatoriais do Estado ou da União, salvo outra definição de responsabilidades definidas por instâncias superiores;

d) Vinculação de clientela e sistematização da oferta de serviços através do cadastramento dos usuários do SUS;

e) Prestação dos serviços básicos de saúde e acompanhamento, no caso de referência interna ou externa ao municipio, dos demais serviços prestados aos munícipes;

f) Contratação, controle, auditoria e pagamento aos prestadores de serviços básicos de saúde;

g) Operação do Sistema de Informação Ambulatorial (SIA) do SUS;

h) Autorização das internações hospitalares e procedimentos ambulatoriais especializados realizados no municipio;

i) Execução das ações básicas de vigilância sanitária, epidemiologia, de controle de doenças e ocorrências mórbidas decorrentes de causas externas; 
j) Avaliação permanente do impacto das ações do Sistema sobre as condições de saúde da população e sobre o meio ambiente;

k) Manutenção do cadastro atualizado das unidades assistenciais sob gestão municipal;

1) Elaboração do relatório anual de gestão, submetido à apreciação e aprovação pelo Conselho Municipal de Saúde.

O Município em Gestão Plena do Sistema Municipal tem, além das atribuições listadas acima, as seguintes:

a) Responsabilidade pela gerência de unidades hospitalares do estado e da União;

b) Garantia de prestação de serviços de referência aos não-residentes no território;

c) Operação de centrais de controle de procedimentos ambulatoriais e hospitalares;

d) Contratação, controle, auditoria e pagamento aos prestadores de serviços ambulatoriais e hospitalares;

e) Administração da oferta de procedimentos ambulatoriais de alto custo e procedimentos hospitalares de alta complexidade;

f) Operação do Sistema de Informações Hospitalares - SIH/SUS e

g) Execução de ações de média e alta complexidade em vigilância sanitária. 
Em novembro de 1999, entre os 5.506 municipios brasileiros, encontravam-se em gestão plena da atenção básica 4.849 municipios e em gestão plena do sistema de saúde 494 municípios, totalizando 5.343 municípios, ou seja, 97,04\% (MINISTÉRIO DA SAÚDE, 2000). Em dezembro de 2.000, 5.450 municipios e 8 estados haviam sido habilitados em uma das formas de gestão da NOB 01/96, representando $99,7 \%$ da população brasileira. No Estado de São Paulo, em janeiro de 2.002, apenas um entre os 645 municipios, não se encontra em gestão plena.

Enquanto esse processo de descentralização ocorre na politica nacional de saúde, na Saúde do Trabalhador, em particular, é na segunda metade da década de 80 que projetos de inclusão desse campo na saúde são implementados, sendo pioneiros os de Salto, $A B C D$, Bauru, Baixada Santista, Campinas, Vale do Ribeira e Zona Norte da Cidade de São Paulo, programas estes vinculados à estrutura dos governos estadual ou municipais (COSTA e cols., 1989).

Até então, a assistência médica aos trabalhadores era executada pelos serviços médicos de empresa e pelo INAMPS, sendo que a fiscalização dos ambientes de trabalho era realizada pelo Ministério do Trabalho, a quem também cabia a normatização das condições de trabalho. Nesta época era inexistente ou incipiente a preocupação sindical com o tema.

A vinculação da Saúde do Trabalhador com a Política Nacional de Saúde ocorre a partir da implantação desses programas, que se legitimam através de uma aproximação política com o movimento sindical e com ações técnicas de grande alcance, que redundaram, por exemplo, no aumento do diagnóstico e registro de doenças profissionais, como o caso do Programa de Salto, que em 1984 teve apenas um registro de doença profissional no 
INSS e em 1985 teve o registro de 101 casos e no primeiro semestre de 1986, 96 casos (COSTA e cols., 1989).

No entanto, é somente com a promulgação da Constituição Federal de 1988, com a promulgação das constituições estaduais em que a Saúde do Trabalhador teve grande destaque e com a Lei Orgânica da Saúde que a Saúde do Trabalhador passou a ter um arcabouço legal definido, passando a fazer parte do SUS.

No Estado de São Paulo, um Projeto de Lei do Deputado Roberto Gouveia foi transformado na Lei 9505/97 (SÃo PAULO, 1997) e disciplina as açōes e serviços de saúde do trabalhador no SUS, constituindo-se em grande avanço na definiçōes legais das ações de assistência ao trabalhador e de vigilância dos ambientes de trabalho.

Os gestores de saúde de todos os municípios habilitados de acordo com a NOB 01/96 devem passar prontamente a promover ações em saúde do trabalhador para assumir as suas novas responsabilidades, se já não estiverem com essas ações implantadas na rede, como acontece com diversos deles, principalmente aqueles que estão localizados em áreas com forte componente econômico industrial e com movimento sindical forte e organizado.

Segundo a Coordenadora Geral de Saúde do Trabalhador do Ministério da Saúde, um estudo realizado pela instituição identificou que cerca de 200 municípios brasileiros possuem serviços públicos de saúde do trabalhador (SENA, 2000). No Estado de São Paulo, estudo realizado pela Secretaria Estadual de Saúde em 1999, contabilizou a existência de 99 municípios com Programa de Saúde do Trabalhador (OTANI, 2001). 
Para a implantação desses serviços, os gestores municipais deverão recorrer não só àqueles municípios que já têm implantadas essas açōes, mas também aos órgãos técnicos das secretarias estaduais de saúde e às universidades, que têm se preocupado em apoiar a descentralização como estratégia para o fortalecimento do Sistema Único de Saúde. 


\subsection{Formulação de uma Política Municipal em Saúde do Trabalhador}

Nas palavras de MINAYO-GOMEZ e THEDIM-COSTA (1997), a área de Saúde do Trabalhador, no Brasil, tem uma conotação própria, reflexo da trajetória que Ihe deu origem e vem constituindo seu marco referencial, seu corpo conceitual e metodológico. Constitui-se em uma meta, um horizonte, uma vontade que entrelaça trabalhadores, profissionais de serviços, técnicos e pesquisadores que possuem compromisso com a mudança do quadro de saúde da população trabalhadora.

A atuação em saúde do trabalhador supõe desde o agir politico, jurídico e técnico ao posicionamento ético, obrigando a definições claras diante de um longo e conturbado percurso, que é próprio dos movimentos por melhores condições de vida e de trabalho; pelo respeito ou desrespeito das empresas à legislação existente e pela precária intervenção do Estado no espaço laboral.

A Saúde do Trabalhador envolve o empenho tanto de setores sindicais atuantes frente a determinadas situações mais problemáticas das suas categorias, quanto ações institucionais em instâncias diversas conduzidas por profissionais comprometidos em sua opção pelo pólo trabalho.

A Saúde do Trabalhador, enquanto questão vinculada às políticas gerais, de caráter econômico e social, implica desafios das mais diversas ordens. Desde os colocados a partir do cenário macroeconômico que impõe diretrizes e prioridades do mercado, aos que se relacionam mais diretamente ao setor saúde. Nesse universo, estão presentes as resultantes das políticas de emprego, salário, habitação, transporte, educação, entre outras politicas econômicas e sociais do Estado. 
Entende-se como politica de saúde as formas, historicamente determinadas, de o Estado reagir às condições de saúde da população e aos seus determinantes, através da produção, distribuição e regulação de bens e serviços que afetam a saúde dos indivíduos e da coletividade (PAIM, 1999).

Ao iniciar o processo de formulação de uma Política Municipal de Saúde do Trabalhador, o gestor deve elencar toda a gama de condicionantes da saúde e da doença no trabalho, para definir a execução de ações intra e intersetoriais que interfiram no processo, eliminando ou atenuando a influência dessas condições na saúde da população trabalhadora.

Na definição e consolidação das práticas de saúde pública, deve-se abranger desde a promoção da saúde até à reabilitação, passando pela vigilância dos ambientes e processos de trabalho e pela assistência aos portadores de doenças ocupacionais e vítimas de acidentes de trabalho.

O gestor municipal deve também levar em conta que não é apenas o setor saúde que executa ações de atendimento à pessoa exposta ao risco de adoecimento ou morte no trabalho. Também os setores do Trabalho, da Previdência Social, as Universidades, o Ministério Público Federal e Estadual, os Sindicatos de Trabalhadores, os Sindicatos de Empregadores e outras instituições governamentais ou não, se incumbem, seja por dever legal, seja por iniciativa própria ou determinada pela pressão social ou decorrente de acordo trabalhista, da execução de algumas tarefas nesse espaço da atenção à saúde.

As empresas, de acordo com o número de empregados e o grau de risco, seguindo a determinação da Norma Regulamentadora $n^{\circ} 4$, da Portaria 3.214/78 do Ministério do Trabalho e Emprego devem constituir um 
Serviço Especializado em Segurança e Medicina do Trabalho (MINISTÉRIO DO TRABALHO E EMPREGO, 1978). Inicia-se a obrigação de constituição desse serviço, com a presença de um técnico de segurança do trabalho, nas empresas de pequeno porte e/ou de risco pequeno, chegando a um serviço mais complexo, com médico, engenheiro de segurança, enfermeira, auxiliar de enfermagem e técnico de segurança do trabalho, em número que também varia na dependência do tamanho e do grau de risco da empresa.

Desta forma, o gestor municipal deverá buscar coordenar as ações a serem executadas pelo SUS com aquelas que são desenvolvidas pelas outras instituiçōes públicas ou privadas, levando em conta, no entanto, as diferentes bases, concepções, práticas e objetivos dos outros serviços, os quais podem não confluir ou coincidir com a Política Municipal de Saúde do Trabalhador.

De acordo com DIAS (2.000), as açōes de um programa de saúde dos trabalhadores podem ser sumarizadas em:

1. Assistência aos trabalhadores vitimas de acidentes do trabalho, doenças profissionais ou doenças relacionadas ao trabalho, compreendendo as ações de diagnóstico, estabelecimento do nexo com o trabalho e recuperação da saúde, envolvendo tratamento e reabilitação, quando necessário.

2. Procedimentos visando o acesso dos trabalhadores cobertos pelo Seguro de Acidentes do Trabalho da Previdência Social aos benefícios previstos na legislação.

3. Ações de promoção e proteção da saúde, que incluem vigilância das condiçōes e ambientes de trabalho, normatização e fiscalização.

4. Capacitação e treinamento de recursos humanos.Informação e educação dos empregadores, trabalhadores e outros setores sociais envolvidos ou interessados no tema. 
A rigor, nenhuma das açōes, isoladamente, constitui novidade para os serviços de saúde. $O$ aspecto inovador da Saúde do Trabalhador é a tentativa de implementá-las de modo articulado, a partir de um referencial teórico e instrumentos de abordagem das relações trabalho-saúde-doença que buscam integrar as dimensões individual, coletiva, técnicas e politicas envolvidas.

As principais características da atenção à saúde dos trabalhadores podem ser sintetizadas por:

1. Integralidade das práticas, ou indissociabilidade das ações preventivas e curativas;

2. Necessidade de uma atuação transdisciplinar e interinstitucional;

3. Complexidade e dinamismo decorrentes das mudanças nos processos produtivos e

4. Participação dos trabalhadores enquanto sujeitos das açōes de saúde.

A abordagem integral da questão saúde-trabalho é obrigatória, se o propósito é a resolução ou o encaminhamento do problema do trabalhador. É ética e tecnicamente inaceitável que, diante de um quadro de acidente ou doença do trabalho, sejam adotados apenas procedimentos tradicionais de diagnóstico e tratamento, quando disponiveis, sem uma atuação sobre as condições de risco presentes no ambiente e/ou nas condições de trabalho, aos quais o trabalhador deve retornar, superado seu impedimento, assim como a investigação e a orientação dos demais trabalhadores expostos ou doentes.

Esta integralidade completa-se pela abordagem do processo saúdedoença do indivíduo e coletivo de trabalhadores de um determinado estabelecimento de trabalho, ou categoria profissional, e amplia-se para a comunidade no entorno e consumidores dos produtos, na perspectiva 
ambiental, envolvendo, simultaneamente, trabalhadores, moradores, consumidores em diversos sub-sistemas formados em função dos riscos e impactos que podem advir do processo de trabalho, uso de recursos naturais, circulação de produtos e tratamento de rejeitos.

A magnitude do desafio da atenção à saúde dos trabalhadores pode ser avaliada, quantitativamente, pela população a ser atendida, estimada em 1997, no Brasil, em 75,2 milhões de pessoas, que integram a força de trabalho. Destas, 36 milhões encontram-se inseridas no mercado formal de trabalho, sendo 22 milhões segurados pelo INSS e 14 milhões distribuídos entre militares, estatutários, empregados domésticos e outros cobertos também pela ação dos setores governamentais do Trabalho e da Previdência (SENA, 2000).

Qualitativamente, esta complexidade se expressa na multiplicidade e diversidade dos processos de trabalho, desenvolvidos no Pais, quanto à incorporação tecnológica, organização do trabalho, relações de trabalho e perfil dos trabalhadores. O dinamismo das mudanças nos processos de trabalho faz com que novas tecnologias, novos produtos químicos e novas formas de organizar e gerir o trabalho, de impacto desconhecido sobre a saúde dos trabalhadores, sejam continuamente incorporados.

A complexidade do objeto para a elaboração de um Programa Municipal de Saúde do Trabalhador requer uma abordagem necessariamente inter e transdisciplinar. Várias áreas do conhecimento Ciências Médicas, Toxicologia, Engenharia, Higiene, Ergonomia, Sociologia, Antropologia, Ciências Políticas, Informática, Administração e Economia entre outras, têm contribuido com teorias, instrumentos e metodologias, para mudar o olhar, melhorar a compreensão e ampliar a intervenção nos problemas. 
É importante destacar que os problemas de saúde dos trabalhadores, à semelhança de outras questões de Saúde Pública, dificilmente podem ser resolvidos por ações exclusivas do setor Saúde. As ações mais eficazes para a garantia da saúde dos trabalhadores, principalmente aquelas que se inserem no campo da promoção e da proteção da saúde, estão mais no âmbito da Economia, da Ciência e Tecnologia, na esfera da organização da produção, do que, propriamente, no setor Saúde, requerendo, portanto, uma abordagem intersetorial e interinstitucional.

O controle social tem um significado particular na atenção à saúde dos trabalhadores. $O$ resgate do saber do trabalhador sobre as relações trabalho-saúde-doença, e a necessidade da democratização da informação são questões centrais, fazendo com que os trabalhadores passem de objeto das ações de saúde a sujeitos deste processo, pelo conhecimento que detêm sobre o processo de trabalho e seu impacto sobre a saúde e pela possibilidade de, organizados, promoverem mudanças nas condições geradores da doença e da morte.

Um capitulo que trata, especificamente, do controle social em Saúde do Trabalhador encontra-se mais adiante, nesta Tese. 


\subsection{Organização de Serviços de Saúde do Trabalhador no Municipio}

No campo da saúde, assumir a atuação na área da saúde e trabalho não significa a simples ampliação de um serviço a mais na rede do SUS; significa entender a complexidade do problema e construir estruturas capazes de responder a essa necessidade.

No contexto de reflexão critica quanto à limitação dos modelos vigentes de atenção ao trabalhador, criam-se os alicerces para o surgimento dessa nova forma de apreender a relação trabalho-saúde, de intervir nos ambientes de trabalho e conseqüentemente de introduzir, na Saúde Pública, práticas de atenção à saúde dos trabalhadores, no bojo das propostas da Reforma Sanitária Brasileira, ampliando a visão da Medicina do Trabalho e da Saúde Ocupacional. (MINAYO-GOMEZ e THEDIM-COSTA, 1997).

O MINISTÉRIO DA SAÚDE (1998) publicou a Norma Operacional de Saúde do Trabalhador - NOST-SUS - complementar à NOB 01/96, com o objetivo de orientar e instrumentalizar a realização das ações de saúde do trabalhador, urbano e rural, pelos Estados, o Distrito Federal e os Municipios, com os seguintes pressupostos básicos:

I - universalidade e eqüidade, onde todos os trabalhadores, urbanos e rurais, com carteira assinada ou não, empregados, desempregados ou aposentados, trabalhadores em empresas públicas ou privadas, devem ter acesso garantido a todos os niveis de atenção à saúde;

II - integralidade das açōes, tanto em termos do planejamento quanto da execução, com um movimento constante em direção à mudança do modelo assistencial para a atenção integral, articulando açōes individuais e curativas com ações coletivas de vigilância da saúde, uma vez que os agravos à saúde, advindos do trabalho, são essencialmente preveníveis: 
III - direito à informação sobre a saúde, por meio da rede de serviços do SUS, adotando como prática cotidiana o acesso e o repasse de informaçōes aos trabalhadores, sobretudo os riscos, os resultados de pesquisas que são realizadas e que dizem respeito diretamente à prevenção e à promoção da qualidade de vida;

IV - controle social, reconhecendo o direito de participação dos trabalhadores e suas entidades representativas em todas as etapas do processo de atenção à saúde, desde o planejamento e estabelecimento de prioridades, o controle permanente da aplicação dos recursos, a participação nas atividades de vigilância em saúde, até a avaliação das ações realizadas:

V - regionalização e hierarquização das ações de saúde do trabalhador, que deverão ser executadas por todos os niveis da rede de serviços, segundo o grau de complexidade, desde as básicas até as especializadas, organizadas em um sistema de referência e contra-referência, local e regional;

VI - utilização do critério epidemiológico e de avaliação de riscos no planejamento e na avaliação das ações, no estabelecimento de prioridades e na alocação de recursos;

VII - configuração da saúde do trabalhador como um conjunto de açōes de vigilância e assistência, visando à promoçăo, à proteção, à recuperação e à reabilitação da saúde dos trabalhadores submetidos a riscos e agravos advindos do processo de trabalho.

Aos Municipios caberá realizar as ações discriminadas, conforme a condição de gestão, plena do sistema municipal de saúde ou plena da atenção básica em que estejam habilitados, como seguem: 
Na Gestão Plena da Atenção Básica, o Municipio assumirá as seguintes ações de saúde do trabalhador:

5. garantia do atendimento ao acidentado do trabalho e ao suspeito ou portador de doença profissional ou do trabalho, por meio da rede própria ou contratada, dentro de seu nivel de responsabilidade da atenção, assegurando todas as condições necessárias para o acesso aos serviços de referência, sempre que a situação exigir;

6. realização de ações de vigilância nos ambientes e processos de trabalho, compreendendo a identificação das situações de risco e a tomada de medidas pertinentes para a resolução da situação e a investigação epidemiológica;

7. notificação dos agravos à saúde e os riscos relacionados com o trabalho, alimentando regularmente o sistema de informações dos órgãos e serviços de vigilância, assim como a base de dados de interesse nacional;

8. estabelecimento de rotina de sistematização e análise dos dados gerados no atendimento aos agravos à saúde relacionados ao trabalho, de modo a orientar as intervenções de vigilância, a organização dos serviços e das demais ações em saúde do trabalhador;

9. utilização dos dados gerados nas atividades de atenção à saúde do trabalhador, com vistas a subsidiar a programação e avaliação das açōes de saúde neste campo, e alimentar os bancos de dados de interesse nacional. 
Na Gestão Plena do Sistema Municipal, assumirá, além das já previstas pela condição de Gestão Plena da Atenção Básica, as seguintes ações de saúde do trabalhador:

10. emissão de laudos e relatórios circunstanciados sobre os agravos relacionados com 0 trabalho ou limitações (seqüelas) deles resultantes, por meio de recursos próprios ou do apoio de outros serviços de referência;

11. instituição e operacionalização de um sistema de referência para o atendimento ao acidentado do trabalho e ao suspeito ou portador de doença profissional ou do trabalho, capaz de dar suporte técnico especializado para o estabelecimento da relação do agravo com o trabalho, a confirmação diagnóstica, o tratamento, a recuperação e a reabilitação da saúde, assim como para a realização dos encaminhamentos necessários que a situação exigir;

12. realização sistemática de ações de vigilância nos ambientes e processos de trabalho, compreendendo o levantamento e análise de informações, a inspeção sanitária nos locais de trabalho, a identificação e avaliação das situaçōes de risco, a elaboração de relatórios, a aplicação de procedimentos administrativos e a investigação epidemiológica ;

13. instituição e manutenção de cadastro atualizado das empresas classificadas nas atividades econômicas desenvolvidas no Município, com indicação dos fatores de risco que possam ser gerados para o contingente populacional, direta ou indiretamente a eles expostos; $\mathrm{A}$ Norma prossegue, afirmando que o Município deverá manter unidade especializada de referência em Saúde do Trabalhador, para facilitar a execução das ações previstas neste artigo. 
De acordo com LACAZ (2000), a organização das açōes e serviços voltados para a atenção à saúde dos trabalhadores no inicio dos anos 80 estava baseada numa estratégia de incorporá-la na rede de serviços de Saúde Pública, isto é, os Centros de Saúde e Ambulatórios de Especialidades, como parte da atribuição do médico clínico geral, numa perspectiva de apreender a clientela, tanto de trabalhadores do mercado formal como informal, a partir de sua inserção no processo produtivo e não como meros consumidores de receitas e prescriçōes e de atuar mediante ações de vigilância dos locais de trabalho.

Porém, num segundo momento, ao final dos anos 80 , esta lógica é alterada. Isto ocorre a partir da ênfase que é dada à atuação de médicos do trabalho numa outra "rede", cujo modelo é agora constituido pelos Centros de Referência em Saúde dos Trabalhadores - CRST - que não conseguem avançar em termos de maior eficácia no controle dos agravos e de cobertura da clientela de trabalhadores, até porque não conseguem envolver a rede de serviços básicos de saúde, acarretando um alto custo para o possivel resultado que gera, não conseguindo constituir-se como alternativa aos convênios médicos e aos próprios Serviços Especializados de Segurança e Medicina do Trabalho - SESMT - das empresas.

Para a implantação de ações de saúde do trabalhador, que vem sendo exigida no processo de descentralização das ações de saúde, alguns municipios têm utilizado o modelo do Centro de Referência em Saúde do Trabalhador - CRST que vem sendo implantado no Brasil e principalmente em São Paulo desde o final da década de 80 . Os atuais CRST são órgãos "centros" e verticalizados, unidades de saúde diferenciadas e subordinadas diretamente aos secretários municipais de saúde, com equipes especializadas multiprofissionais que desempenham tarefas de assistência e procuram realizar algumas ações de vigilância sanitária, que na verdade 
se tratam de ações de suporte do Poder Judiciário, mas que não conseguem se inserir na rede ambulatorial e hospitalar do SUS, e são vistos pelas demais unidades como ilhas autônomas com as quais poucos vínculos podem ser estabelecidos (RIBEIRO e cols., 1998).

De forma diferente, outros municípios vêm preferindo incluir o atendimento ao trabalhador nas unidades básicas de saúde, como a Estância Hidromineral de Poá, na Grande São Paulo, que vem implantando esse serviço com assessoria de pesquisadores da Área de Saúde do Trabalhador da Faculdade de Saúde Pública da USP (REPULLO JUNIOR \& LEAL, 1997).

O Municipio de Diadema, localizado na região do $A B C$ Paulista, implantou o Programa de Saúde do Trabalhador, apoiado no atendimento descentralizado nos pronto-socorros, como sugerido em proposta elaborada nas atividades da Disciplina de Gerenciamento de Serviços de Saúde no Trabalho da Faculdade de Saúde Pública da USP (REPULLO JUNIOR, 1994).

Há, no entanto, opiniões divergentes, que pregam a construção de unidades especializadas em saúde do trabalhador. Em 1993, assim se expressou CARNEIRO:

"As tentativas de construção diretamente na rede sem contar com uma retaguarda especializada têm sido fadadas ao insucesso. A demanda do dia a dia nas unidades básicas, nos ambulatórios, nos hospitais ou nos pronto-socorros, inviabiliza o pensar em outras ações, mesmo que na verdade não sejam outras. A discussão de estratégias sem apresentar modelos ou tentar generalizar experiências, supera por um lado as concepções de programas verticalizados e de sistemas generalistas por outro. 
As experiências dentro das clínicas de especialidades também mostram que existem poucas possibilidades de sucesso, trata-se de uma cultura de abordagem integral ainda minoritária, que estabelece uma disputa com o modelo teórico-clínico consolidado há décadas mesmo que seja mais do ponto de vista das práticas do que das concepções. Não será convivendo no mesmo espaço ou dispersando os poucos recursos humanos interessados que estará garantida a implantação.

Várias críticas podem ser feitas àqueles que optaram pela construção de unidades especializadas, porém somente nestes locais é possivel identificar a realização de ações de forma sistematizada, estes serviços têm funcionado como pólos irradiadores das práticas e concepções da saúde do trabalhador para o conjunto da rede, principalmente se levarmos em consideração que lidamos com uma rede básica ainda marcadamente materno-infantil e os trabalhadores não constituem a clientela habitual. $A$ universalização das ações de saúde do trabalhador, portanto só terão condições de serem implantadas quando forem do conhecimento da rede, tiverem sido elaboradas, dissecadas, normatizadas e mais do que isso, a rede esteja convencida da importância e principalmente da viabilidade e da capacidade de serem absorvidas na prática diária.

Se encararmos as açōes de saúde do trabalhador como um conjunto de práticas que incluem: a assistência, a vigilância epidemiológica, a vigilância sanitária e os seus desdobramentos necessários como compreensão da legislação, articulação sindical e trabalho interinstitucional, chegaremos à conclusão que a implantação das ações de saúde do trabalhador no conjunto dos equipamentos da rede pública não prescindirá da mudança do atual 
modelo assistencial vigente, ainda baseado nas práticas médicas. Em outras palavras, a implantação destas ações requer a quebra radical com o modelo clínico e a construção de práticas baseadas fundamentalmente nas ações de vigilância à saúde, principal e intransferivel tarefa a ser construída pela estrutura estatal. "

Um dos entrevistados, assim explicou o funcionamento do serviço, demonstrando como a sua organização ocorreu:

"O objetivo do Ambulatório de Saúde do Trabalhador é fazer diagnóstico. Uma dúvida que nós tínhamos no princípio era trabalhar com um modelo que não fosse o de Centro de Referência, chegamos a pensar até em contratar médicos do trabalho e colocar no Núcleo de Especialidades, trabalhar a Medicina do Trabalho como se fosse uma especialidade clinica. Depois nós vimos que esse não era o modelo ideal, o certo, o modelo mais adequado seria que essas pessoas tivessem um olhar de vigilância mesmo, vigilância à saúde e que se pudesse estar observando através dos diagnósticos, possiveis situações de risco para fazer intervenção. Então, o Ambulatório existe e se consolidou mesmo, não há mais nenhuma dúvida hoje em relação ao modelo adotado, porque nós achamos assim, desde que esteja bem definido qual é o seu papel. O ambulatório não tem um papel de fazer tratamento, o objetivo é de fazer identificação de casos e diagnóstico, e ai nos temos porta para demanda espontânea, porta para demanda encaminhada pelos sindicatos, advogados, Ministério Público, uma série de demandas institucionais e as demandas voluntárias, e da rede básica também, e do próprio serviço dos prontos-socorros também em demanda de todos os tipos, ou para diagnóstico, ou para avaliação de incapacidades, de avaliação de seqüelas, avaliação de reinserção no trabalho e acompanhamento da readaptação. 
Esses médicos trabalham com olhar de vigilância à saúde, eles fazem esse atendimento, encaminham para tratamento os casos que nós conseguimos imediatamente encaixar numa referência e damos algum tipo de acompanhamento enquanto essas pessoas não conseguem se inserir. Então, um dos médicos do trabalho é reumatologista, então ele tem um olhar mais voltado para essa questão; outra médica é endocrinologista, não tem muito a ver com a área, mas como clínica, tenta dar uma resposta clínica enquanto não encaixa as pessoas mas isso aí é uma coisa bem transitória. As pessoas, rapidamente, são colocadas em outras referências e a gente faz um encaminhamento um pouco mais da questão ocupacional propriamente e da readaptação."

Nesse Município, o Programa de Saúde do Trabalhador está organizado em

1. Atendimento às urgências/emergências dos acidentes de trabalho nos Pronto-Socorros e Pronto-Atendimentos, os quais dão seguimento aos casos no tocante ao tratamento médico e encaminhamento previdenciário;

2. Ambulatório de Saúde do Trabalhador (com médicos e fonoaudióloga) que realiza avaliações auditivas, atende aos casos que tiveram seu primeiro atendimento em clínicas conveniadas ou fora do Município, casos que necessitam de uma avaliação em Medicina do Trabalho mais especializada ou que demandam um encaminhamento previdenciário mais complexo, como, por exemplo, recursos administrativos junto ao INSS; 
3. Núcleo de Vigilância em Saúde do Trabalhador que inclui o sistema de informação e atividades de vigilância dos ambientes e processos de trabalho.

Em outro município estudado, o atendimento dos casos foi descentralizado para duas unidades básicas de saúde localizadas em regiões pólo da cidade, para o Ambulatório de Especialidades e para a Santa Casa, a depender da complexidade do tratamento que se requer. Esses serviços, além de promoverem o atendimento clínico, realizam também o manejo previdenciário do caso. Além destes, há o Ambulatório de Saúde do Trabalhador, localizado no centro da cidade, para onde são referenciados alguns casos, onde estão localizados o atendimento em fonoaudiologia e a Vigilância em Saúde do Trabalhador.

Um outro municipio, que baseava as ações exclusivamente em Centros de Referência em Saúde do Trabalhador, hoje está modificando a organização do sistema. Assim se expressou o Assistente Técnico entrevistado:

"Em 1989, quando começou o Programa de Saúde do Trabalhador, o debate girou em torno de duas formas de organização. Uma era que se devia construir centros de referência em saúde do trabalhador e outra que não se devia construir centros de referência e que se devia apostar todas as fichas em capacitar a rede para fazer ações em saúde do trabalhador. Na primeira possibilidade, dos CRST, se entendia que a rede também tinha que ser capacitada. A diferença era de estratégia! Quem defendia essa idéia achava que precisava do Centro de Referência para difundir cultura e conhecimento em Saúde do Trabalhador; quem defendia a outra idéia achava que se construisse o CRST podia virar um gueto. Venceu a proposta de construir os CRST e acabou se apostandn na 
idéia de construir cinco CRST, depois construiu mais um e na prática, o que a gente verificou é que houve uma certa 'guetização'. Todos os problemas acabaram sendo encaminhados para o Centro de Referência e a rede incorporou muito pouco a Saúde do Trabalhador".

Tendo como objeto de estudo a organização da atenção à Saúde do Trabalhador nesse mesmo municipio, SPEDO (1.998) avalia que a implantação de CRST, em que pese as justificativas, representou e continua representando uma importante limitação para a construção do modelo de atenção à Saúde do Trabalhador, que seguisse tanto os princípios e diretrizes das Conferências de Saúde do Trabalhador já realizadas, quanto os dos documentos do Ministério da Saúde, referindo-se à NOST-SUS.

Prossegue a Autora afirmando que, enquanto estratégia para implantar ações em toda a rede de serviços do SUS, ao invés de atingirem esse objetivo, os Centros de Referência estariam reforçando a concepção de que a saúde do trabalhador é um campo complexo que necessitaria de serviços e recursos humanos altamente especializados para o seu desenvolvimento. A complexidade do campo é real, porém ela se situa muito mais no campo político, do que no técnico.

A saúde do trabalhador, por suas caracteristicas, enfrenta de forma mais direta o conflito capital/trabalho. Como o caráter técnico das ações nessa área é dado pelos referenciais da Saúde Coletiva, toda a rede de serviços de saúde do SUS poderia incorporar em sua prática açōes de saúde do trabalhador, reconhecendo o trabalho, enquanto categoria central na determinação do processo saúde-doença, seja para suspeitar de diagnósticos, seja para avaliar situações de risco em ambientes específicos. Essa área não difere de qualquer outra, cujo modelo de atenção busca a 
integralidade, nas quais deve-se prever serviços com distintos níveis de complexidade e de atenção.

É importante reconhecer que existe uma certa especificidade do campo e que, tanto para desenvolver as açöes assistenciais, quanto para as ações de vigilância, os serviços e os profissionais ainda não estão devidamente capacitados. Contudo, esse fato, por si só, não justifica a concentração dessas ações em um único serviço, ao invés de se investir na capacitação e disseminação desses conhecimentos de forma mais ampla. Nesse sentido, conclui a Autora, nesse Municipio estudado não se deveria implementar uma única estratégia, sendo importante considerar a existência de outros caminhos para estruturar um programa de atenção em saúde do trabalhador.

As divergências entre as duas estratégias, uma que propõe a implantação dos serviços junto à rede básica de saúde e outra, que propõe a criação dos CRST, ocorre não só nesse Municipio, mas é objeto de debate na Academia, entre técnicos da área e em serviços de saúde do trabalhador.

$\mathrm{Na}$ maior parte dos municipios, implantaram-se os CRST, pois era majoritária entre os profissionais que atuavam no setor, a opinião de que esta era a melhor proposta de organização de serviços. Concorreu também para esse posicionamento, a implantação e funcionamento do Centro de Referência em Saúde do Trabalhador do Estado de São Paulo - CEREST, evolução institucional do Programa de Saúde do Trabalhador da Zona Norte de São Paulo, ligado à Secretaria de Estado da Saúde. Criado após uma tentativa frustrada de incluir nas ações desenvolvidas pelos Centros de Saúde da região as ações de Saúde do Trabalhador, sua atuação teve grande repercussão técnica e politica, tornando-se um paradigma para o setor. 
No entanto, esse modelo mostrou-se ao longo do tempo, limitado, restringindo-se ao atendimento de uma demanda selecionada, encaminhada pelos sindicatos, advogados e pelo Ministério Público, sem conseguir dar conta da universalidade da atenção.

A estratégia "Centro de Referência" implica também em prejuizo no que toca à integralidade. Nos CRST, o individuo é atendido por uma equipe multiprofissional de Saúde do Trabalhador, especializada na atenção aos problemas de saúde decorrentes das condições inadequadas de trabalho e que o aborda com história e inserção social especificas. No entanto, não há integração com as demais unidades e programas de saúde. Enquanto os CRST especializam-se no atendimento à demanda saúde-trabalho, as demais unidades do Sistema de Saúde deixam de ser capacitadas para o atendimento básico em Saúde do Trabalhador, não havendo rotinas estabelecidas para esse tipo de atenção. As pessoas portadoras de doenças ocupacionais são imediatamente encaminhadas para os CRST, sem que se haja um primeiro atendimento na unidade básica e que se busque uma atenção integral.

Os CRST são porta de entrada para toda a demanda decorrente dos problemas de saúde relacionados ao trabalho, não se constituindo em serviços de referência secundária para o sistema de saúde. As demais unidades não atendem os individuos que buscam atenção em Saúde do Trabalhador, encaminhando-os diretamente para os CRST.

Propõe-se que o serviço de atenção à Saúde do Trabalhador seja organizado de forma hierarquizada e que as unidades básicas de saúde realizem o primeiro atendimento do trabalhador. Deve ser feita inicialmente, uma sensibilização da equipe, buscando sobretudo eliminar preconceitos que remontam à época anterior ao SUS, quando cabia exclusivamente ao 
INAMPS $\circ$ atendimento aos portadores de doenças do trabalho. Em seguida, devem ser elaboradas rotinas e protocolos de atendimento ao trabalhador e ser feita a capacitação da equipe para a compreensão do processo saúde-doença-trabalho. Os casos que, pela complexidade técnica, não puderem ser resolvidos nas unidades básicas de saúde, devem ser referenciados a uma unidade especializada, como um Ambulatório de Especialidades, no qual exista pessoal da área de Saúde do Trabalhador, como médico do trabalho, fonoaudiógo, psicólogo etc. 


\subsection{Recursos Humanos - a inter $e$ a transdisciplinaridade}

A transdisciplinaridade, segundo ALMEIDA FILHO (1997), além de ser uma palavra comprida, que soa bem e impressiona audiências incautas seduzidas por novidades, sobre ela só há uma certeza. É a de que se refere a um conceito em busca de sistematização.

VASCONCELOS (1.996) assinala que a transdisciplinaridade é uma radicalização da interdisciplinaridade, com a criação de um campo teórico, operacional ou disciplinar de tipo novo e mais amplo.

Antes de prosseguir, cabe uma breve discussão sobre a história e a etimologia do termo "disciplina" e seus derivados, recorrendo-se novamente ao trabalho de ALMEIDA FILHO (1.997) que assim discorre sobre o assunto:

"Em um sentido contemporâneo comum, a palavra disciplina conota rigor na atuação, um certo ascetismo, uma continuidade ou perseverança no enfrentamento de problemas. $O$ antônimo 'indisciplina' refere-se em geral a um defeito de conduta (comporta pois um julgamento moral) de alguém que não segue as regras ou que carece de efetividade por dispersão ou confusão. Em Latim, a palavra 'discipulus' parece ter sido empregada inicialmente em oposição a 'magister', primeiro num contexto de iniciação religiosa; depois o sentido da palavra se estende progressivamente aos domínios intelectual e artistico. Os 'discipuli' eram originalmente os seguidores de um mestre, de uma escola ou de um grupo, passando em seguida a designar aqueles que aderiam à filosofia ou ao método de uma escola ou que se ligavam a um mesmo modo de pensar. Nesta família semântica, a disciplina inicialmente significava a ação de aprender, de instruir-se; em seguida, a palavra foi empregada para referir-se a um tipo particular de iniciação, a uma doutrina, $\curvearrowright$ um 
método de ensino. Posteriormente, veio a conotar o ensinoaprendizado em geral, incluindo todas as formas de educação e formação. Por metonímia, a partir do século XIV, com a organização das primeiras universidades ainda no contexto da escolástica, disciplina passou a designar uma matéria ensinada, um ramo particular do conhecimento, o que depois viria a se chamar de 'ciência'. Por extensão, a disciplina tornou-se equivalente a princípios, regras e métodos característicos de uma ciência particular."

Segundo ainda o Autor, há uma classificação evolutiva das alternativas de interação ou integração dos distintos campos disciplinares, com as seguintes etapas sucessivas: multidisciplinaridade, pluridisciplinaridade, interdisciplinaridade auxiliar, metadisciplinaridade, interdisciplinaridade e transdisciplinaridade.

Por estar o conceito de transdisciplinaridade em construção e debate, na bibliografia estudada, verifica-se ora a utilização do conceito de interdisciplinaridade, ora do conceito de transdisciplinaridade, porém não contrapostos, mas sim denotando a busca pela caracterização da Saúde do Trabalhador como um campo complexo, que não pode ser explicado por modelos lineares de determinação, sendo a resultante do cruzamento de diferentes discursos e práticas disciplinares.

No texto elaborado pelo CEREST/SP (1.996), a interdisciplinaridade é uma particularidade da atuação em saúde do trabalhador e é necessária que exista. Se em outras áreas essa metodologia é uma meta a ser atingida e mesmo que não o seja, é possível se avançar, na área de saúde e trabalho, torna-se crucial a integração e a atuação conjunta entre as várias disciplinas, pois o trabalho e sua relação com a saúde só podem ser entendidos se houver os olhares do médico, enfermeiro, assistente social, 
engenheiro, ergonomista, sociólogo, toxicologista, educador, psicólogo, químico, advogado e demais profissionais tradicionalmente ligados ou não à área da saúde.

ALMEIDA FILHO (1.997) baseia a transdisciplinaridade na possibilidade de comunicação não entre campos disciplinares, mas entre agentes em cada campo, através da circulação não dos discursos, mas pelo trânsito dos sujeitos dos discursos entre os campos disciplinares. Segundo - Autor, não há campo científico contemporâneo mais justificadamente transdisciplinar que a Saúde Coletiva.

A adoção da transdisciplinaridade na abordagem dos problemas confere legitimidade social e cientifica às açōes, ao possibilitar que o objeto sob investigação seja de domínio de todos e de cada um dos participantes das ações, independente de sua formação original, técnica ou empirica (FADEL DE VASCONCELOS e RIBEIRO, 1997).

Neste sentido, a atuação transdisciplinar rompe com o caráter de ação conjugada, em que cada membro da equipe "faz a sua parte" isoladamente, superando o simples somatório de conhecimentos técnicocientíficos e facultando a todos os membros da equipe a apropriação dos diversos conhecimentos em jogo na definição do objeto.

A Saúde do Trabalhador compreende um corpo de práticas teóricas interdisciplinares - técnicas, sociais, humanas - e interinstitucionais, desenvolvidas por diversos atores situados em lugares sociais distintos e informados por uma perspectiva comum. Essa perspectiva é resultante de todo um patrimônio acumulado no âmbito da Saúde Coletiva, com raizes no movimento da Medicina Social latino-americana e influenciado significativamente pela experiência italiana (MINAYO-GOMEZ e THEDIMCOSTA, 1997). 
A Instrução Normativa de Vigilância em Saúde do Trabalhador (MINISTÉRIO DA SAÚDE, 1998), assim orienta a questão da inter/transdisciplinaridade, no item ESTRATÉGIAS:

"Onde já existam estruturas, estaduais e municipais, de saúde do trabalhador - Programas, Coordenações, Divisōes, Gerências, Centros, Núcleos - promover e/ou aprofundar a relação institucional com as estruturas de Vigilância Epidemiológica, Vigilância Sanitária e Fiscalização Sanitária, buscando a superação da dicotomia existente em suas práticas, em que 0 objeto de ação da vigilância, em geral, não contempla o processo de produção e sua relação com a saúde dos trabalhadores. Com esse intuito, recomenda-se a constituição de equipes multiprofissionais para a execução de ações interdisciplinares e pluriinstitucionais."

Um dos entrevistados assim informou sobre a composição da equipe de Saúde do Trabalhador em seu Município:

"No começo eram duas pessoas, durante um ano ficou assim. Ao fim de um ano, nós tivemos mais um administrativo e mais um médico do trabalho e, já no final de 96, nós inauguramos a cabine audiométrica e tivemos uma fono que começou a trabalhar conosco.."

Atualmente, a equipe nesse Municipio é composta por 3 médicos, sendo que um deles também coordena o serviço, um engenheiro de segurança do trabalho, uma fonoaudióloga e dois administrativos. A médica coordenadora do serviço e a fonoaudióloga são especialistas em Higiene Industrial.

Outro entrevistado, de outro municipio, assim explica a composição da equipe: 
"Então era eu, enfermeira e coordenadora, uma escriturária, o médico e a fonoaudióloga. Em maio de 1996 foi inaugurado o Ambulatório. O médico tinha jornada parcial no Programa, a escriturária também, só eu e o médico éramos só do Programa, mas ele tinha só 20 horas de jornada. Nessa época, a gente só fazia assistência, não fazia vigilância. Depois disso teve toda aquela mudança, entraram outras pessoas e aí sim, como o Prefeito gosta dessa área, deu muito incentivo a essa área e o Secretário também, mudamos para um prédio maior e aí vieram duas escriturárias, um psicólogo, a fonoaudióloga em tempo integral, a médica também, integral e ai aprimoramos a assistência e começamos a trabalhar a parte de vigilância."

Em outro municipio, as ações de saúde do trabalhador são prestadas por médicos, enfermeira, psicóloga, assistente social, fonoaudiólogas, engenheiros de segurança do trabalho, técnicos de segurança do trabalho e terapeuta ocupacional, além da equipe de apoio, constituída por escriturários, auxiliares de enfermagem e serventes.

Verifica-se em todas as entrevistas, que os programas municipais de saúde do trabalhador estudados são desenvolvidos por equipes multiprofissionais. Em alguns deles, o processo de trabalho é pluridisciplinar, como definida por ALMEIDA FILHO (1997):

"Pluridisciplinaridade implica a justaposição de diferentes disciplinas cientificas que, em um processo de tratamento de uma temática unificada (no caso a Saúde do Trabalhador) efetivamente desenvolveriam relações entre si. Seria, portanto, ainda um sistema de um só nivel, porém os objetivos aqui são comuns, podendo existir algum grau de cooperação mútua entre as disciplinas. De todo modo, 
envolvendo campos disciplinares situados num mesmo nível hierárquico, há uma clara perspectiva de complementaridade, sem no entanto ocorrer coordenação de ações nem qualquer pretensão de criar uma axiomática comum."

Nesses municipios em que o trabalho classifica-se como pluridisciplinar, os profissionais possuem um objetivo comum, com algum grau de colaboração entre si, mas sem a definição de um campo integrador e coordenador e sem pretensão de se criar uma axiomática comum. Já em outros, pode-se definir o trabalho como interdisciplinar, como se percebe no trecho desta entrevista:

“(...)chegamos a pensar até em contratar médicos do trabalho e coloca-los em ambulatório de especialidade, trabalhar médico do trabalho como se fosse uma especialidade clínica e depois nós vimos que esse não era o modelo ideal, o certo, o modelo mais adequado, seria que essas pessoas (refere-se aos profissionais que realizam o atendimento dos trabalhadores) tivessem um olhar de vigilância mesmo, vigilância à saúde e que pudessem estar observando, através dos diagnósticos possiveis, situações de risco para fazer intervenção. Então, o ambulatório existe, se consolidou mesmo sem mais nenhuma dúvida hoje, não tem mais nenhuma dúvida em relação ao modelo adotado, porque nós achamos assim: que esteja bem definido qual é o papel do ambulatório, o ambulatório não tem um papel de fazer tratamento, o objetivo é fazer identificação de casos e diagnóstico, para se realizarem as ações de vigilância."

Aqui existe um axiomática comum a todos os profissionais que é a vigilância à saúde. A quase totalidade dos profissionais do serviço possuem grande experiência em vigilância de ambientes de processos de trabalho, sendo que dois deles são especialistas em Higiene Industrial, como foi 
verificado na visita feita à unidade. Todos trabalham tendo como campo integrador e mediador dos discursos disciplinares a vigilância em saúde do trabalhador, o que caracteriza a interdisciplinaridade, como definida por ALMEIDA FILHO (1997):

"Interdisciplinaridade implica uma axiomática comum a um grupo de disciplinas conexas, cujas relações são definidas a partir de um nivel hierárquico superior, ocupado por uma delas. Esta última, geralmente determinada por referência à sua proximidade da temática comum, atua não somente como integradora e mediadora da circulação dos discursos disciplinares mas, principalmente, como coordenadora do campo disciplinar."

Não foi observado em nenhum dos serviços visitados, processos de trabalho que pudessem ser caracterizados como transdisciplinares, que tenham criado um campo novo, que tenham desenvolvido um autonomia teórica e metodológica perante as disciplinas que os compõem, numa radicalização da interdisciplinaridade. No entanto, verifica-se uma tendência, uma disposição e um clima favorável para que isto venha a acontecer. Esse campo novo, parece ser o da Vigilância em Saúde, que agregaria todas as disciplinas, inclusive as de outras áreas externas à Saúde do Trabalhador, em um campo particular com uma axiomática geral compartilhada, numa estrutura de horizontalização das relações de poder.

Ressaltam dos textos que abordam a Saúde do Trabalhador, inferências de que a área é, por natureza, inter/transdisciplinar. Analisar ambientes e processos de trabalho, compreender o processo saúdedoença-trabalho e nele intervir com ações no campo político, técnico e jurídico, tornam a inter/transdisciplinaridade uma exigência que, ao mesmo tempo em que preserva a autonomia de cada área envolvida, articula os 
conhecimentos e se amplia, ultrapassando os limites da somatória de todas elas.

A necessidade de responder às demandas dos trabalhadores expostos aos riscos dos ambientes de trabalho cria condiçōes para o fortalecimento das disciplinas em particular, mas também para a abertura de suas fronteiras, no sentido transformador, na criação de novos campos, na instituição de novas práticas mais apropriadas para o tratamento do objeto.

O principio da hierarquia que rege os processos de trabalho em saúde tradicionais, deve ser substituído pelo princípio da cooperação, do diálogo, do questionamento entre os saberes e práticas, abrindo-se também para o conhecimento dos próprios trabalhadores.

A formação dos profissionais na graduação, calcada no estabelecimento de relações de saber/poder e no receio de estabelecer contatos entre as diferentes disciplinas, começa a ser questionada e os cursos de pós-graduação em Saúde Coletiva e Saúde do Trabalhador, pela sua composição multiprofissional e pela natureza interdiscipinar das práticas que são repassadas aos alunos, vêem estimulando a crítica a essas posturas reducionistas. 


\subsection{Recursos Humanos - Capacitação e Desenvolvimento de Pessoal}

Há pouca informação bibliográfica sobre capacitação e desenvolvimento de pessoal em saúde do trabalhador. Entre 1987 e 1990 ocorreu um treinamento de profissionais do Programa de Saúde do Trabalhador da Secretaria de Estado da Saúde, que envolveu docentes da Faculdade de Saúde Pública da USP. Esse treinamento teve como objetivo qualificar os profissionais em atividades administrativas e técnicas relacionadas à área (SILVEIRA DE QUADROS e cols., 1992).

Foram realizados quatro cursos:

1. Preparação de Coordenadores de Saúde do Trabalhador - 40 horas aula - destinado a profissionais de nivel universitário aos quais caberiam as atividades de gerenciamento dos Programas de Saúde do Trabalhador;

2. Qualificação de Coordenadores de Acidentes do Trabalho - 40 hs. aula - destinado a médicos aos quais caberiam as atividades de fiscalização da assistência médica prestada ao acidentado no trabalho, assim como participar da vistoria nas empresas onde ocorressem os acidentes de maior gravidade;

3. Treinamento no diagnóstico e tratamento das doeçcas profissionais, com o objetivo de melhorar as condições de diagnóstico e tratamento das doenças ocupacionais, dividido em cinco módulos de 20 horas aula cada. Os 
temas tratados foram Doenças causadas por Chumbo, Poeiras, Agrotóxicos, Ruído e Solventes.

4. Preparação de Agentes de Inspeção do Trabalho, com duração de 40 hs/aula, organizado para médicos e engenheiros ligados à área de saúde e trabalho.

Concluiu-se, após entrevista de $64,6 \%$ dos alunos dos quatro cursos, que houve uma influência positiva para as atividades de saúde do trabalhador nas regiões de saúde do Estado de São Paulo.

Na $11^{\text {a }}$ Conferência Nacional de Saúde, realizada em Brasília (DF) entre 15 a 19 de dezembro de 2.000, que teve como tema "Acesso, Qualidade e Humanização na Atenção à Saúde, com Controle Social", um dos aspectos debatidos foi a formação e capacitação de recursos humanos para o SUS. Os participantes concluíram que a formação dos profissionais não está orientada, hoje, para o atendimento da população usuária do SUS. Há deficiência técnica e ética na formação do profissional que chega ao serviço, que precisa ser melhor preparado quanto à humanização (MINISTÉRIO DA SAÚDE, 2.001).

Essa é uma preocupação que sempre esteve presente nas entrevistas realizadas. Um dos entrevistados, em cujo município a forma de organização da prestação de ações de saúde do trabalhador está sendo descentralizada para toda a rede de atenção, informou que caberá aos CRST a tarefa de formação e capacitação dos profissionais da rede para essa nova incumbência.

Um dos municípios estudados, que iniciou 0 atendimento de Acidentes de Trabalho de forma descentralizada por suas unidades de 
urgência e emergência, realizou treinamento com todos os médicos envolvidos nesse trabalho e assim foi relatado o processo:

"Nós fizemos o treinamento em maio e junho. Nesse momento, nós pegamos aproximadamente 400 médicos do Hospital, do Prontosocorro, do Pronto Atendimento do Bairro $X$, do Pronto Atendimento do Bairro $Y$, dos serviços que existem nas Unidades Básicas de Saúde e começamos com médicos, enfermeiras, assistentes sociais, auxiliares de enfermagem, com o pessoal de recepção. A idéia era que é necessário identificar casos e tornar o tema da saúde do trabalhador, um tema que tivesse encaminhamento dentro do sistema. O sistema, na hora que entrasse em contato com o programa relacionado, se assumisse como um problema de saúde que fosse da sua competência da mesma forma como já havia respostas às questões da saúde da mulher, da criança, do idoso, e já tinham alguns frutos definidos. A gente queria massificar um pouco essa questão da informação sobre saúde do trabalhador $e \quad 0$ treinamento foi voltado para todas essas categorias. Médicos eram 400, foram feitos treinamentos assim, de dia e de noite, durante várias semanas para atingir as equipes dos treinamentos dentro dos serviços.

O treinamento era basicamente de uma sensibilização para o problema, sensibilização sobre o que era a problemática da saúde do trabalhador no País como um todo, em São Paulo e o que a gente tinha visto na pesquisa que aplicamos no Pronto-Socorro. (...) Esse treinamento era mais ou menos isto.."

E prossegue o entrevistado: 
"Então, as respostas eram dadas, então a idéia nossa era que - trabalhador tivesse as mesmas respostas que as outras pessoas que procuravam o sistema tinham e mais aquelas que fossem especificas para o trabalhador. Então, a gente trabalhou muito com os médicos nessa questão, que foi um trabalho de um ano. Após o treinamento durante esse ano aí, a gente teve muita resistência, mas a gente foi minando esta resistência e trabalhando esta resistência em cima de debate, qual a diferença, do ponto de vista da assistência clínica, do ponto de vista da assistência médica, do que você dá para o trabalhador e do que você dá para uma pessoa. Quando eles colocaram que isso era demanda para médico de trabalho, a gente dizia: olha não é acidente do trabalho, a lesão; o nome da lesão não é acidente de trabalho, o nome da lesão é fratura, é entorse, é ruptura de tendão e com isso tentar tirar um pouco a mistificação que havia. Um dos objetivos do treinamento também era desmistificar um pouco essa coisa que era o acidente de trabalho e o que era o atendimento, isso o que era o atendimento ao acidentado do trabalho. Eu me colocava como retaguarda para avaliações de casos que houvesse dúvida ao final do tratamento clínico sobre a questão da inserção profissional, eu era retaguarda como médico do trabalho e fazia essa retaguarda da questão ocupacional, da especificidade da questão ocupacional."

Nas universidades públicas, há cursos de formação e capacitação de profissionais para a área de saúde do trabalhador. Um dos mais procurados é o Curso de Especialização em Saúde do Trabalhador e Ecologia Humana da Escola Nacional de Saúde Pública, no Rio de Janeiro, com carga horária total de 410 horas (FIOCRUZ, 2.001). O objetivo do Curso é propiciar aos participantes um referencial teórico-metodológico e prático que os capacite para o desenvolvimento de ações no campo da Saúde do Trabalhador, na perspectiva de construção de atividades e programas relacionados ao 
enfrentamento dos problemas de saúde decorrentes do trabalho. O curso dirige-se, prioritariamente, a profissionais de nivel superior, de formaçōes diversas, que desenvolvam ou pretendam desenvolver atividades de serviço, particularmente no âmbito do SUS, assim como àqueles vinculados às atividades de saúde de sindicatos de trabalhadores ou à docência/pesquisa no campo da Saúde do Trabalhador.

O curso está organizado por áreas temáticas, assim distribuídas:

1. Trabalho e saúde

2. Política nacional de saúde do trabalhador

3. Descrição e análise das situações de trabalho

4. Gênero, trabalho e saúde

5. Educação, saúde e trabalho

6. Processo de adoecimento relacionado à exposição ambiental e ocupacional

7. Saúde mental e trabalho

8. Vigilância em saúde do trabalhador

9. Avaliação e gerenciamento de riscos

A graduação do pessoal de nível universitário para a Saúde do Trabalhador, tanto para a área de cuidados (Medicina, Enfermagem, Fonoaudiologia, Psicologia etc), como para a área de segurança (Engenharia, Física etc) é feita em currículos destinados à colocação do profissional no mercado de trabalho público ou privado, mas que obedeça a lógica do capital, ou seja, da introdução de novas tecnologias voltadas rara 
- diagnóstico e tratamento das doenças, para a introdução de novas técnicas e procedimentos na organização do trabalho que garantam produtividade, sendo que os temas ligados à Saúde do Trabalhador são tratados superficialmente, quando incluidos no curriculo.

Busca então, o profissional, a especialização em Saúde do Trabalhador e a encontra, na maior parte das vezes, também voltada para 0 trabalho em empresas, pois em poucas ocasiōes, esta pós-graduação está vinculada a programas de formação em Saúde Coletiva, como a da Escola Nacional de Saúde Pública e poucas outras.

Cabe então, aos serviços de Saúde do Trabalhador, a tarefa de prover a capacitação e desenvolvimento de seu pessoal, o que é feito através de cursos preparados junto a instituições universitárias ou a docentes que possuam experiência na área e afinidade com o campo da Saúde do Trabalhador, não se encontrando institucionalizada, de forma generalizada e em número apropriado à demanda do setor, a formação de pessoal para a atuação em Saúde do Trabalhador no SUS.

É uma questão que cabe às instituições do SUS e às universidades analisar, pois com a habilitação dos municípios segundo a NOB 01/96, a edição da NOST-SUS, as pressões que estão sendo e serão realizadas pelos sindicatos e até micro e pequenas empresas para que os municipios implementem ações de Saúde do Trabalhador, a capacitação de profissionais para a área está inapropriada do ponto de vista qualitativo e insuficiente do ponto de vista quantitativo. 


\subsection{Recursos Materiais}

Não se encontrou referência bibliográfica sobre recursos materiais necessários para a implantação de ações de Saúde do Trabalhador. Um dos entrevistados, assim se expressou sobre o assunto, após esclarecer que no início, o Programa só tinha um microcomputador:

"Nós temos dois computadores, temos cabine audiométrica com impedanciômetro, isso para avaliação biológica. Para avaliação ambiental, a Saúde do Trabalhador não tem equipamento. Nós temos equipamento do SESMT da Prefeitura, ligado à Secretaria de Administração, que tem lá termômetro de bulbo, anemômetro, decibelímetro. Nós fazemos são as avaliações qualitativas, o trabalho tem sido feito muito em cima de avaliações qualitativas."

Outro entrevistado, assim se pronunciou sobre os recursos materiais disponiveis no Programa de Saúde do Trabalhador:

"Quando começamos o que conseguimos adquirir com o dinheiro que veio foi montar o consultório médico, montar a sala da coordenação com um computador e uma impressora e montar a sala de audiometria com uma cabine e o audiômetro, decibelímetro, luximetro e termômetro. Faziamos avaliações ambientais de forma pontual, não tínhamos uma rotina de vigilância."

Em uma das entrevistas, foi informado que os programas de saúde do trabalhador que fizeram parte de um projeto de cooperação entre os governos do Brasil e da Itália receberam, a título de doação, equipamentos de avaliação ambiental como medidor de nivel de pressão sonora, de nivel de conforto térmico e luxímetro e compartilham entre si equipamentos mais 
complexos, como medidores de concentração de gases, os quais também foram doados, mas em menor número.

Os Programas de Saúde do Trabalhador não têm veículos próprios, compartilhando-os com outras áreas da Prefeitura ou da Secretaria Municipal de Saúde. Quanto aos equipamentos de avaliação ambiental, verifica-se que estão à disposição das ações de vigilância dos ambientes de trabalho.

Pela análise de recursos materiais encontrados nos serviços, verificase que, além de equipamentos e material de escritório, equipamentos e material médico-hospitalar básico, como mesa de exames, balança, esfigmomanômetros, estetoscópios, termômetros etc e o sistema de microinformática, os quais podem ser considerados essenciais, o equipamento para diagnóstico de lesões auditivas, ou seja, a cabine acústica, o audiómetro e o impedanciómetro, com todos os seus acessórios, vem logo em seguida na lista de prioridades. Isto porque a perda auditiva induzida por ruído situa-se entre as mais freqüentes patologias ocupacionais,.principalmente em municipios onde o ramo industrial é importante. Esse equipamento, no entanto, pode ser compartilhado pelos outros setores do sistema de saúde, de acordo com a demanda existente para o procedimento.

Os equipamentos de avaliação ambiental, principalmente o medidor de nivel de pressão sonora, têm sua importância na medida em que podem ser utilizados para a aferição de avaliações realizadas pelas empresas ou por serviços por ela contratados. No entanto, são extremamente caros, não só na aquisição, como na manutenção. A utilização compartilhada desses equipamentos por programas municipais próximos, como no exemplo citado anteriormente, é uma solução que deve ser levada em conta, pois a utilização desses equipamentos não é cotidiana. 
É importante deixar claro que, de forma alguma, a aquisição de equipamentos de avaliação ambiental é imprescindivel ou essencial para a implantação do Programa Municipal de Saúde do Trabalhador, encontrandose estes materiais numa escala inferior de prioridade para o serviço, mesmo o de vigilância dos ambientes e processos de trabalho. 


\subsection{Sistema de Informações}

A informaçăo é essencial à tomada de decisões (MOTA e CARVALHO, 1999). O conhecimento sobre a situação de saúde requer informações sobre o perfil de morbidade e mortalidade, os principais fatores de risco e seus determinantes, as características demográficas e informações sobre os serviços, como a disponibilidade de recursos humanos, de infra-estrutura e financeiros.

A informação é elemento essencial para a vigilância em saúde do trabalhador, para a administração e planejamento dos serviços e das açōes de assistência e reabilitação, e para gerar conhecimento e consciência crítica sobre os riscos que devem ser enfrentados para a garantia da saúde dos trabalhadores (CARMO, 1996). A construção de um sistema de informação que produza conhecimentos e que descreva a realidade tornase, portanto, elemento estratégico na definição de uma política de saúde do trabalhador.

Dados sobre a populaçăo exposta (número de trabalhadores empregados, número de segurados da Previdência Social, número de horas-homem de trabalho etc), ou seja, os denominadores dos indicadores epidemiológicos, existem em várias fontes, como por exemplo, as do Ministério do Trabalho (Relação Anual de Informações Sociais - RAIS), as da Previdência Social, ou mesmo de instituições não governamentais como - Serviço Social da Indústria - SESI e outras. Nem sempre, no entanto, estes sistemas săo de fácil acesso, nem tampouco permitem a desagregação das informações para niveis local e regional.

Uma fonte de informações sobre os acidentes de trabalho, inclusive os não registrados pela Previdência, são os serviços de assistência médica, visto que, em princípio, a grande maioria dos trabalhadores acidentados ou 
portadores de doenças ocupacionais deve receber algum tipo de assistência.

Sobre a fonte de informações ser o serviço de assistência médica, assim se expressou um dos entrevistados:

"O primeiro instrumento de coleta de dados que era um instrumento que chamamos desde o inicio de RAAT (Relatório de Atendimento do Acidentado do Trabalho) era um instrumento que tinha duas finalidades. Tinha a primeira finalidade de ser relatório médico, servir como LEM, e como instrumento de notificação para o sistema de vigilancia. E outro era guardar a memória do atendimento, quando a gente sabe que dentro do pronto-socorro tem um fluxo de papel muito transitório, os papéis saem de lá vão para outro lugar e tal e isso e uma coisa de ter um prontuário e trabalhar toda vida, era feito em três vias e estava com estas destinações que eu coloquei."

Uma outra fonte importante de informações em saúde do trabalhador que, no entanto é pouco utilizada, é a Declaração de Óbito. Sobre essa forma de registro, STOUT e BELL (1991) ao afirmarem que a Certidão de Óbito e os dados de exames médicos são as duas fontes disponiveis para identificar todos os casos de lesões fatais no trabalho numa dada área geográfica, dão conta que, nos EUA, os Certificados de Obito são preenchidos para cada morte que ocorre e seguem um formato padrão que inclui um item indicando se esta foi devida a uma lesão ocorrida no trabalho. No entanto, a precisão e consistência desse dado são questionáveis porque não existe uma padronização nacional do que venha a ser morte no trabalho, tanto nos EUA como no Brasil e possivelmente em vários outros países. Por exemplo, acidentes com veículos automotores e homicidios no trabalho são particularmente subnotificados como mortes ocorridas no trabalho nos Certificados de Óbito. 
No Brasil, também, as Certidões de Óbito possuem campo destinado ao preenchimento de informações em caso de acidente do trabalho, porém, também, a subnotificação é bastante grande, não se conhecendo estudos que tenham dimensionado esse assunto.

Um dos municipios estudados utiliza as Declarações de Óbito como fonte de informação. Assim explicou o entrevistado:

"Através do Programa Municipal de Aprimoramento de Informações de Mortalidade, que tem um convênio com o Serviço Funerário e recebe todas as Declarações de Óbito e melhora a qualidade das informações, a gente tem lá uma parte das declarações em que está assinalado que é acidente do trabalho. Isso demanda um trabalho de investigação. Outra fonte são as delegacias de policia. Nós fomos percebendo que o óbito não chega até a gente nem pela CAT, nem pela informação do Pronto Socorro, porque boa parte das mortes ocorrem no local do acidente e não vão parar no Hospital, mas no Instituto Médico Legal - IML. O IML só coloca na Declaração de Obito que é acidente de trabalho quando a Delegacia de Polícia informa explicitamente. Se não informar, o IML não coloca que é acidente do trabalho. Hoje, estamos achando que a Delegacia é a fonte principal de informações sobre óbito no trabalho. Por isso, montamos essas equipes especiais que fazem a busca ativa nas delegacias, através dos boletins de ocorrência policial. Há dois programas principais, um voltado para óbitos na construção civil e outro para óbitos entre 'motoboys"

SOUSA CAMPOS (1999) alerta para um problema: há cada vez um grau maior de especialização dos sistemas de informação. Em geral, estão sendo organizados de maneira estanque, separados das instâncias 
responsáveis pelo planejamento e gestão dos serviços encarregados da intervenção concreta na realidade. Separaçăo entre coletores e analisadores de informação e aqueles que teriam autoridade e capacidade para intervir. Distanciamento entre a informação das instâncias responsáveis pelo planejamento e pela administração dos serviços. Fratura entre a Vigilância Sanitária e a Vigilância Epidemiológica. A Saúde Pública confinada à Epidemiologia Descritiva.

Em termos operacionais, a epidemiologia organiza e relaciona a informação de saúde com o processo de trabalho; identifica, descreve e analisa características comuns e heterogêneas das repercussões sanitárias em distintos estratos de trabalhadores; e possibilita a construçăo de grupos estratificados segundo caracteristicas comuns relacionadas ao processo de trabalho. Nesse sentido, a análise sucessiva da heterogeneidade dos grupos homogêneos é ferramenta fundamental (HUET MACHADO, 1997).

A simplificação essencial que o método epidemiológico opera nesse processo diz respeito à conjugação das abordagens disciplinares da medicina do trabalho, da higiene industrial e da engenharia de segurança em uma abordagem clássica de saúde ocupacional. Pode também articularse de forma interdisciplinar ao incorporar o processo de trabalho como categoria e objeto fundamental de sua reflexão e intervenção, configurandose em abordagem, de Saúde do Trabalhador.

Portanto, os dados de histórias ocupacionais e de avaliações clínicas, os indicadores biológicos de doses internas e de efeitos, as avaliações ambientais, as identificações de situações de risco potencial, as análises ergonômicas e de outras disciplinas, as avaliações qualitativas e de percepção de riscos com os próprios trabalhadores e técnicos são dimensionadas por intermédio da epidemiologia nesse processo de 
simplificação, estabelecendo diferenças e similaridades dos efeitos ou impactos na saúde às também similares ou distintas exposições.

A Instrução Normativa de Vigilância em Saúde do Trabalhador (MINISTÉRIO DA SAÚDE, 1998-a) orienta sobre as informações necessárias e as suas fontes:

"As informações de interesse para as ações em saúde do trabalhador, atualmente disponíveis, limitam-se à avaliação do perfil de morbi-mortalidade da população em geral, sem lograr o conhecimento sistemático dos riscos e o dimensionamento da população trabalhadora a eles exposta, que permitam a análise e a intervenção sobre seus determinantes.

É pensando na necessidade de se avançar nesse conhecimento para fins de intervenção e prevenção efetivas dos agravos relacionados ao trabalho, que foi definido o elenco de informações aqui apresentadas, sem perder a perspectiva de ser acrescidas outras de interesse local, regional ou mesmo nacional, à medida que o sistema de informações em saúde do trabalhador se estruture e se consolide.

\section{1 - Informaçōes acerca da mortalidade.}

As informações de mortalidade serão coletadas principalmente a partir da Declaração de Óbito, por intermédio do Sistema de Informações sobre Mortalidade. Cada Município deverá investir na melhoria da qualidade dos dados da Declaração de Óbito e, sempre que possivel, cruzar com outras informações disponiveis, principalmente a Comunicação de Acidente de Trabalho (CAT), da Previdência Social. 
7.2 - Informações acerca da morbidade

As informações de morbidade podem ser obtidas de diversas fontes, tais como a Ficha Individual de Notificação de Agravos, referente às doenças incluídas no Sistema de Notificação de Agravos Notificáveis - SINAN; a Comunicação de Acidente do Trabalho (CAT), normalmente utilizada para os trabalhadores do mercado formal de trabalho, regido pela Consolidação das Leis Trabalhistas (CLT); as fichas, prontuários e outros documentos oriundos dos atendimentos ambulatoriais (SIANSUS) e de internaçōes (SIH/SUS) na rede de serviços de saúde.

Os Estados e os Municípios poderão definir eventos-sentinela a ser notificados, incluindo-os no SINAN. Essa definição deverá ter por referência a análise do parque produtivo local ou a suspeita da existência de um agravo não diagnosticado como relacionado ao trabalho. $A$ análise dos eventos-sentinela constituir-se-á em atividade complementar ao sistema de informações, particularmente neste momento em que o diagnóstico de doenças é muito reduzido. Observar, por exemplo, excessos de mortes ou morbidade por alguns tipos de canceres ou de achados laboratoriais (leucopenias, anemias) que possam estar ocorrendo em grupos especificos de trabalhadores.

7.3 - Informações relativas às atividades e aos processos produtivos

Essas informações deverão ser obtidas à medida que os Estados e os Municípios executem e implantem as ações de vigilância. Consideram-se, neste caso, Cadastros de 
Estabelecimentos, Relatórios de Inspeção, Termos de Notificação e Fichas de Vigilância. Outras informações, utilizando os bancos de dados da RAIS e do IBGE, também poderão ser incorporadas, devendo ser desagregadas, por Municipio, para que possam ser adequadas aos niveis locais.

Outras fontes de informação que deverão ser utilizadas, à medida que o sistema se capacite para tal, são as dos serviços médicos e de segurança e higiene industrial de empresas, do Anexo 1 da CIPA, dos sindicatos, das associações patronais, dos serviços/institutos de medicina legal, de associaçőes e entidades civis (associações de moradores, grupos ecológicos, culturais), de outros órgãos da administração pública (DETRAN, secretarias de proteção ambiental, de indústria e comércio, do trabalho etc). Devem ser considerados ainda estudos epidemiológicos e resultados de pesquisas de interesse da área de saúde do trabalhador, como fonte de informações.

Um maior detalhamento acerca da criação de bancos de dados e adequação das informações em saúde do trabalhador aos Sistemas de Informação existentes, considerando, entre outros, a coleta, o fluxo, o processamento, a análise e a divulgação das informações, será efetuado em publicaçăo posterior.

Os Estados e os Municipios poderão acrescentar outras informaçōes e metodologias que julgarem pertinentes, inclusive sugerindo sua incorporação em âmbito nacional nas publicações subseqüentes." 
Um dos entrevistados fez um longo depoimento, muito esclarecedor, sobre o Sistema de Informação para a Vigilância em Saúde do Trabalhador no seu Município:

"A idéia nossa, desde o início, era trabalhar um instrumento de notificação de agravo e esse instrumento de notificação não poderia ser a CAT, porque a CAT tinha um filtro, quer dizer, além de identificar casos, tinha um filtro da pessoa ter um vínculo formal, do contrato em $C L T$ e tal. O instrumento de notificação principal era o Relatório de Atendimento de Acidentado de Trabalho - RAAT - e até hoje ela é usada para todos os casos, é feita a notificação na RAAT. Mas é solicitada a CAT para os trabalhadores que têm Previdência. Hoje nós utilizamos um sistema que é um misto das duas coisas, com algumas particularidades.

Quando a gente foi para esse trabalho maciço de identificação de casos, chegamos a identificar 550 casos. Veja, quando a CAT dava uma identificação na porta, até de dados da própria Previdéncia, mostrava um número médio de 180 a 200 acidentados por mês e quando a gente foi fazer identificação na porta o número era de 550. Dos 550, a gente conseguiu um retorno de CAT de até $70 \%$, naquela época, é até curioso!

Essa história toda de que vinculado à empresa é só $50 \%$, mas a gente chegou até $70 \%$ de notificação de CAT em relação ao tanto que era direcionado pela RAAT.

Inicialmente começamos a trabalhar com EPIINFO, usando todos os códigos do SISCAT para preparar a comparação com o Estado e outros municípios. Depois nós migramos essa entrada de dados para o Access e basicamente pegamos os dados da CAT e da 
RAAT; a parte da assistência vinha da RAAT e os dados de identificação das empresas da CAT. Os dados de identificação da empresa, circunstâncias do acidente eram todos tirados da CAT e da RAAT, que a RAAT também tem.

Hoje trabalhamos com os dados da CAT e da RAAT mas só para aqueles casos que têm CAT, infelizmente é uma realidade nossa, uma limitação. Nós trabalhamos, isso aí dá uma média de $3.200,3.300$ casos/ano, notificados por essa via. Então esses casos são notificados.

São constituídos dois bancos em paralelo com uma chave de relacionamento entre eles, um banco que tem a ver com identificação dos dados do trabalhador, sexo, idade, residência, os dados das circunstâncias do acidente e os dados do atendimento médico, os dados clínicos, diagnósticos, de gravidade da lesão e por aí vai, esse é um banco, isso se constitui um banco e o campo do CGC é um campo de ligação com outro banco que se constrói em paralelo a esse. No momento que é digitado o CGC surge na tela uma lista de empresas que o CGC vai coincidir. No momento que o digitador percebe que a empresa que ele digitou está ali na lista de opções, ele faz a opção e essa empresa, esse CGC fica no campo, fica no banco do Acidente, no banco do evento, do agravo, e o banco do cadastro de empresas está ali confirmando o CGC e ele faz o relacionamento a qualquer hora, pode relacionar todas as variáveis do cadastro de empresas com o evento.

No momento em que não haja coincidência, se o CGC for de uma empresa que não está cadastrada, o sistema abre uma nova tela de cadastramento e nós fazemos a entrada dos dados do cadastro da Empresa. Agora, o uso que a gente faz disso? A dificuldade da área 
de Saúde do Trabalhador é trabalhar o denominador. Nós trabalhamos esse cadastro da empresa, ele é um cadastro que quem nos forneceu foi o Cadastro Imobiliário da Prefeitura e ai ele tem informação das empresas no momento em que elas se cadastraram, muitas delas a atualização não é recente, não é muito atual. “

Quando perguntado sobre o uso da RAIS para se fazer a relação com o CGC, assim prosseguiu o entrevistado:

"Talvez com o CGC seja possivel. Inclusive no cadastro da Prefeitura a gente tem tentado. Vale a pena fazer o que você está falando desde que haja essa possibilidade. Até poderíamos usar o cadastro da RAIS mesmo e não usar mais o da Prefeitura se o campo do CGC for um campo compativel com nosso sistema. Acho que é uma busca a se fazer.

O nosso banco de empresas que já tiveram algum evento relacionado à saúde do trabalhador, chega a mais de 5.000 empresas. Cada empresa que aparece, eu só incluo a partir do momento em que ela tem um acidente, ou uma doença e a gente vai incluindo no cadastro. Eu uso as informações da CAT e uso as informações da Prefeitura. Vejo lá se tem o CEP, o número de trabalhadores e tal e coloco. Acho que é uma coisa que a RAIS já nos daria pronta. O fato é que é assim."

Ao ser perguntado sobre a forma de usar os dados do sistema de informação para o planejamento, assim respondeu o entrevistado:

"Para orientar as ações de vigiláncia, a gente trabalha com alguns critérios. A gente pega freqüencia simples para procurar evidências e começa a ver se tem relação com as empresas. Com as 
empresas maiores, a gente sempre olha essa questão aí, porque tem um maior número de trabalhadores. Com empresas pequenas, a gente sempre olha se estão ocupando espaço lá em cima, também tem um crivo aí. Se a empresa está lá em cima, mas ela pode ser uma notificadora e a que não aparece pode ser uma subnotificadora. Ai criamos alguns critérios.

Pela classificação do SISCAT, tem um critério de gravidade de lesões. Ai a gente faz um coeficiente de gravidade, que é a proporção de acidentes graves em relação ao total dos acidentes notificados. Isso já começa a mostrar um comportamento exatamente oposto àquele da freqüência simples. Al a gente começa a ver as empresas que só notificam acidentes graves, $100 \%$ de todos os seus acidentes são graves e no número absoluto total ela tem um pequeno número de acidentes. Na freqüência simples ela está lá embaixo e no quociente de gravidade ela está lá em cima. É um critério que a gente usa. Outro critério é a proporção de doença profissional em relação ao número de eventos notificáveis e é isso. $E$ por setores, outro critério que a gente usa, também, para escolha de eventuais parceiros, é por base sindical. Então a gente trabalha com o coeficiente, usando o número de trabalhadores da RAIS para o setor, mas é defasado. Eu tenho acesso aos dados da RAIS com dois anos, com três anos."

Como visto pelas entrevistas e textos selecionados, o Sistema de Informações em Saúde do Trabalhador possui especificidades que devem ser levadas em conta na implantação de um Programa Municipal.

Primeiramente, a CAT pode e deve ser utilizada, pois traz informações muito importantes sobre os eventos ocorridos. Mas não deve ser a única fonte de coleta de informações, pois não representa a totaliḍade 
dos eventos ocorridos no processo saúde-trabalho. Deve ser elaborado um instrumento para a coleta de informaçōes que capture todos os casos que ocorram no Município, residindo na recepção dos serviços de urgência um local importante para a coleta dos dados. A quase totalidade dos acidentes de trabalho 'com perda de tempo', ou mesmo os mais leves, procuram os serviços de urgência, pois os serviços de empresa não estão preparados para realizar o primeiro atendimento e os convênios médicos, freqüentemente, não se encontram próximos quando da ocorrência desses eventos, ou então, não cobrem o atendimento de acidentes do trabalho. Por isso, a necessidade de se criar 0 instrumento que seja preenchido na recepção dos pronto-socorros e pronto-atendimentos, tanto pelo pessoal administrativo, como pelos médicos e outros profissionais que intervenham no atendimento.

Para que a cada nova necessidade de informação, não se crie um novo instrumento de coleta que será mais um papel a ser preenchido e circular pelo sistema de saúde, na elaboração desse instrumento de coleta de dados deve ser pensada a possibilidade de que ele venha a substituir relatórios já existentes, como no caso de um dos municipios visitados, que negociou junto à Agência do INSS a substituição do Relatório de Exame Médico - REM - que está anexado à CAT, pelo instrumento elaborado, o qual capta todos os casos atendidos nos serviços de urgência e tem informações sobre a empresa, dados do acidentado e algumas informaçōes sobre $O$ acidente. De acordo com o sistema implantado, esse instrumento pode também substituir a Ficha de Atendimento Ambulatorial - FAA existente em vários serviços.

É importante no Sistema de Informações em Saúde do Trabalhador que exista uma interface entre os casos e as empregadoras, para que se possa dimensionar com a maior exatidão possivel quais são as empresas que apresentam comportamentos que devam ser melhor observados. Há 
casos de empresas que só notificam os acidentes graves, o que pode ser detectado no sistema de informação. Há empresas que nada notificam, o que também merece ser melhor avaliado pelo serviço. Há empresas de mesmo ramo que possuem comportamentos estatísticos completamente diferentes, em número e em gravidade de casos, o que merece, também, uma melhor investigação.

O CGC, ou na atualidade, o CNPJ parece representar a melhor forma de se montar a interface entre o caso e a empresa, pois é um dado que pode ser obtido na CAT, na Carteira Profissional, em cartões comerciais e outras fontes. $O$ cadastro de empresas do município pode ser obtido junto ao setor responsável pela arrecadação de impostos municipais e, mesmo que esteja desatualizado, a sua atualização vai sendo feita pela própria utilização do cadastro.

O obito, ou o acidente de trabalho fatal, representa um importante elemento para o sistema de informação em Saúde do Trabalhador. A dificuldade é que esses casos, em grande parte das vezes, năo chegam aos serviços de saúde e são manejados pela área de Segurança Pública, perdendo-se informações nos documentos elaborados por ela. A viabilização da colocação no Boletim de Ocorrência Policial, de um campo onde se inscreva se esta decorre de um acidente do trabalho é o início de um grande avanço, pois determinará que na Declaração de Óbito, que é um instrumento da Vigilância Epidemiológica, apareça essa informação. Entretanto, será necessário o treinamento e a sensibilização dos policiais para que, primeiro, saibam caracterizar corretamente um acidente do trabalho, o que em várias ocasiões não é fácil, mesmo para pessoas treinadas e, segundo, que inscrevam a informação no Boletim de Ocorrência. 


\subsection{Vigilância dos Ambientes e Processos de Trabalho - Arcabouço Legal}

Segundo Boaventura de Sousa Santos, um dos principais teóricos contemporâneos da corrente do pluralismo jurídico, citado por CAMPILONGO (1992), existem pelo menos quatro contextos estruturais, articulados a quatro modos distintos de produção do direito: o espaço doméstico, o espaço do trabalho, o espaço da cidadania e o espaço mundial. Cada contexto desses cria seu próprio direito. A teoria jurídica tradicional circunscreve sua análise ao espaço da cidadania, caracterizado pelo direito estatal. Os limites de eficácia "dos direitos" de todos esses contextos decorrem dessa redução. A existência de um direito estatal democrático está relacionada com a ausência de democracia nos outros espaços. Exemplificando: uma legislação estatal avançada no campo da proteção à saúde do trabalhador pode ser admitida, mas em termos práticos, as condições sociais e econômicas existentes nas fábricas não permitem que essas regras sejam eficazes.

A tese de Boaventura é a de que esses quatro contextos, dependendo da posição "central" ou "periférica" ocupada pelo país no sistema mundial, fixam limitaçōes e condicionamentos reciprocos. Assim, apenas para argumentar, 0 impacto da voga neoliberal da desregulamentação, por exemplo, é diferente nos EUA e na América Latina. Nos paises centrais, é bem possivel que essa tendência do sistema mundial seja mediada pelo espaço da cidadania e do direito territorial (estatal). A desregulamentação poderia, eventualmente, significar novas formas de regulamentação, com respeito aos direitos do cidadão. 0 mesmo fenômeno, na América Latina, num contexto de estagnação econômica, atraso tecnológico, desemprego, inflaçăo, divida externa ou baixos salários, poderia, ao contrário, significar o esvaziamento completo dos direitos da 
cidadania, reproduzindo um contexto de trabalho tradicionalmente autoritário.

Daí a reserva com que muitos setores recebem as iniciativas estatais de "delegação" para as forças sociais, da resolução de problemas trabalhistas. Essa omissão estatal, sob a capa do participacionismo e da maior legitimidade das decisões tomadas diretamente pelos interessados, pode redundar na reprodução de uma cidadania dos trabalhadores muito fragmentada: nos setores mais articulados do trabalho, avanços significativos, inclusive suplantando as garantias legais; nos setores menos organizados, a inobservância dos mais elementares direitos do trabalhador. Essa tendência pode ser observada em diversos setores da economia brasileira. Verifica-se isso não apenas na comparação entre trabalhadores do campo e da cidade, mas também entre trabalhadores do setor de serviços e do setor industrial etc. Enfim, um neocorporativismo que apenas organiza a desigualdade jurídica.

Também em outros países do Mundo, cabe ao Estado a tarefa de controlar e mediar as relações entre capital e trabalho no tocante ao ambiente de trabalho. Na Itália, o Decreto Legislativo 626/94 introduziu uma importante mudança no modelo italiano de prevenção no local de trabalho, transferindo ao empregador o papel central na tutela da saúde do trabalhador e deixando para o serviço público uma função de "órgão de controle".

De acordo com BARROS DE OLIVEIRA e cols. (1997), ao se adequarem ao preceito de Saúde do Trabalhador da Constituição Federal, as constituições estaduais de 1989, em sua maioria, embora tenham estabelecido seus dispositivos de forma diversa, conferiram ao SUS a capacidade de imprimir à área uma sustentação legal do processo de transformação de suas práticas. A aproximação entre os caracteres da lei e 
da política dela decorrente, efetivamente implementada, leva a supor que, em especial, essas leis especificas possuiam (e possuem) uma capacidade de servir como real instrumento de mudança.

A municipalização não é tarefa banal. Exige um monumental esforço técnico e de inovação institucional, gerencial e assistencial (CARVALHO e col., 1997). Dentro dessa inovação, encontra-se todo o arcabouço legal para as ações de vigilância em ambientes de trabalho a serem executadas pelos municipios.

Ao contrário, por exemplo, do que acontece em vários países, as leis municipais brasileiras são leis, tanto no sentido material (decretos, resoluções, portarias etc) quanto no sentido formal. Assim, uma lei municipal, em matéria de competência explícita e exclusiva do município, definida na Constituição Federal, pode prevalecer sobre a lei ordinária estadual, a constituição estadual e à lei ordinária federal (LORDELLO DE MELLO, 2001)

No Brasil, a competência para legislar sobre "proteção e defesa da saúde" é concorrente, da União, dos Estados e do Distrito Federal ${ }^{2}$ e dos Municipios ${ }^{3}$ (DALLARI, 1991; DALLARI, 1992). Isso significa que cabe à União apenas 0 estabelecimento de normas gerais sobre 0 assunto ${ }^{4}$. Os Estados, que formam a República Federativa do Brasil são competentes para suplementar a legislação posta pela União que, não é demais acentuar, limitar-se-á a estabelecer normas gerais. Esse parecer ser, aliás, o principal papel reservado aos Estados na estrutura constitucional da saúde no Brasil. E, finalmente, cabe aos Municipios, entidades que formam

\footnotetext{
${ }^{2}$ Constituição Federal, art. 24 , XII

${ }^{3}$ Constituição Federal, art. 30, II

${ }^{4}$ Constituição Federal, art. 24, parágrafo $1^{\circ}$
} 
juntamente com os Estados, no dizer do texto constitucional, a República Federativa do Brasil, legislar sobre todos os assuntos de interesse local ${ }^{5}$.

A constituição vigente abandonou a expressão tradicional "peculiar interesse municipal", que não conseguiu definição satisfatória, substituindoa pelo interesse local, igualmente de difícil conceituação. É indispensável porém, compreender-se o conceito de interesse local, haja vista que o sistema constitucional brasileiro é de enumeração de poderes, que delimita de modo estanque as competências de cada esfera de poder político. Assim, salvo expressa disposição da Lei Magna, como nos casos de competência comum previstos no artigo 23 , cada esfera de poder político detém apenas aquelas competências que the foram manifestamente atribuídas. Acentua-se, portanto, a necessidade do correto entendimento do que seja assunto de interesse local quando se quer analisar a competência constitucionalmente municipal.

Durante um século, no Brasil, os Municipios tiveram assegurada sua autonomia em tudo quanto respeitasse ao "seu peculiar interesse" ${ }^{\text {. }}$ E as tentativas de conceituação desse interesse peculiar foram inúmeras. Apenas por volta de 1950, uma definição alcançou relativo respeito, sendo adotada por constitucionalistas de diferentes correntes de pensamento. Trata-se daquela formulada por Sampaio Dória que, após distinguir o privativo do peculiar conclui que o entrelaçamento dos interesses dos Municípios com os interesses dos Estados, e com os interesses da Nação, decorre da natureza mesma das coisas. O que os diferencia é a predominância, e não a exclusividade. Foi o mesmo critério - da predominância do interesse - o princípio norteador da repartição de competências na federação brasileira de 1988. Ora, é evidente que o mundo contemporâneo praticamente não apresenta problemas que tenham reflexos

\footnotetext{
${ }^{s}$ Constituição Federal, art. 30, I

${ }^{6}$ Expressão do art. 68 da Constituição de 1891)
} 
circunscritos ao nível local, nem que sejam particulares a um Estadomembro (nivel regional) ou mesmo que respeitem os limites nacionais.

Em conseqüência, pode-se concluir que os assuntos de interesse local devem ser compreendidos como aqueles referentes ao peculiar interesse municipal que, dentro da melhor técnica legislativa, serão definidos estudando-se caso a caso qual o interesse predominante para a fixação da competência do Município.

Pode-se afirmar, portanto, que o Município brasileiro está duplamente titulado para legislar sobre proteção e defesa da saúde. O primeiro título refere-se à competência para suplementar a legislação federal (limitada a normas gerais) e a estadual no que couber ${ }^{7}$. O segundo, logicamente prioritário, é relativo à predominância do interesse local pela proteção e defesa da saúde como objeto da competência dos Municípios descrita no artigo 30, I, da Carta Magna contemporânea: "legislar sobre assuntos de interesse local".

No tocante à vigilância sanitária e vigilância de ambientes de trabalho, as entrevistas realizadas mostraram que todos os municipios vêm adotando o Código Sanitário Estadual (SÃO PAULO, 1998) para a legalização de suas ações. Um dos municípios aprovou a seguinte Lei, em 1.996, ainda na vigência do antigo Código Sanitário do Estado de São Paulo, criando os mecanismos legais para que passasse a executar as ações de vigilância sanitária:

DISPOE sobre a adoção da Vigilância Sanitária no Municipio.

O Prefeito do Município, Estado de São Paulo, no uso e gozo de suas atribuições legais,

\footnotetext{
${ }^{7}$ Competência enumerada no artigo constitucional - art. 30, II)
} 
FAZ SABER que a Cámara Municipal aprova e ele sanciona e promulga a seguinte Lei:

ARTIGO $1^{\circ}$ - O Municipio deverá promover ações de Vigilància Sanitária, nos termos do artigo 18, inciso IV, alínea "b", da Lei Federal nl 8.080, de 19 de setembro de 1990.

ARTIGO $2^{\circ}$ - Entende-se por vigilância Sanitária, um conjunto de ações capaz de eliminar, diminuir ou prevenir riscas à saúde e de intervir nos problemas sanitários decorrentes do meio ambiente, da produção e circulação de bens e da prestação de serviços de interesse da saúde, abrangendo-.

I - o controle de bens de consumo que, direta ou indiretamente, se relacionem com a saúde, compreendidas todas as etapas e processas, da produção ao consumo; e

II - a controle da prestação de serviços que se relacionam direta ou indiretamente com a saúde.

ARTIGO $3^{\circ}$ - O Município deverá adotar, visando promover ações de Vigilância Sanitária, normas regulamentadoras da atuação do indivíduo e das autoridades e agentes sanitários incumbidos das ações de fiscalização e controle contidas no Código Sanitário Estadual, para dispor especialmente sobre:

I - típificação das infrações sanítárias

II. procedimento de apuração de fatos e definição de responsabilidade de agente causador da ação ou emissão danosa; e 
III. aplicação de sanções administrativas

Em seguida, por Decreto do Prefeito foi regulamentada a Lei, indicando-se as multas e taxas devidas, as formas como os recursos deveriam tramitar e também os servidores que poderiam atuar como Agentes de Inspeção Sanitária, entre eles, os profissionais da Saúde do Trabalhador.

Nesse Município, o arcabouço legal utilizado, então, para a implementação de ações em saúde do trabalhador é a Constituição Federal, a LOS, a Constituição Estadual e além destes, a Lei Orgânica Municipal e a Lei citada acima, que adota o Código Sanitário do Estado e o próprio.

A Lei Orgânica desse Município estabelece que:

Art. 231 - São competências do Municipio, exercidas pela Secretaria de Saúde:

$1-(\ldots$.

VII - a implementação e complementação das normas técnicas do Ministério da Saúde e da Secretaria de Estado da Saúde, de acordo com a realidade municipal;

VIII - (....)

XII - o planejamento e execução das ações de:

1. vigilância sanitária:

2. vigilância epidemiológica;

3. saúde do trabalhador;

4. (....) 
O Código Sanitário do Estado de São Paulo (SÃO PAULO, 1998), tem um título com dois capitulos, voltado para a questão da Saúde e Trabalho :

\section{TÍTULO ॥}

\section{Saúde e Trabalho}

\section{CAPÍtULO I}

\section{Disposiçőes Gerais}

Artigo 29 - A saúde do trabalhador deverá ser resguardada, tanto nas relações sociais que se estabelecem entre o capital e o trabalho, como no processo de produção.

$\S 1^{0}$ - Nas relaçōes estabelecidas entre o capital e o trabalho estão englobados os aspectos econômicos, organizacionais e ambientais da produção de bens e serviços.

$\$ 2^{\circ}$ - As ações na área de saúde do trabalhador previstas neste Código compreendem o meio ambiente urbano e rural.

Artigo 30 - São obrigações do empregador, além daquelas estabelecidas na legislação em vigor:

I - manter as condições e a organização de trabalho adequadas às condições psicofísicas dos trabalhadores;

II - garantir e facilitar o acesso das autoridades sanitárias, Comissōes Internas de Prevenção de Acidentes - CIPAs e representantes dos sindicatos de trabalhadores aos locais de trabalho, a qualquer dia e horário, fornecendo todas as informaçōes e dados solicitados;

III - dar ampla informação aos trabalhadores e CIPAs sobre os riscos aos quais estão expostos;

IV - arcar com os custos de estudos e pesquisas que visem esclarecer os riscos de ambiente de trabalho e ao meio ambiente; e 
V - comunicar imediatamente à autoridade sanitária a detecção de quaisquer riscos para a saúde do trabalhador, sejam fisicos, químicos, biológicos, operacionais ou provenientes da organização do trabalho, elaborando cronograma e implementando a correção dos mesmos.

Artigo 31 - Os órgãos executores das ações de saúde do trabalhador deverão desempenhar suas funções, observando os seguintes princípios e diretrizes:

1 - informar aos trabalhadores, CIPAs e respectivos sindicatos sobre os riscos e danos à saúde no exercicio da atividade laborativa e nos ambientes de trabalho;

II - assegurar a participação das CIPAs, das comissões de saúde e dos sindicatos de trabalhadores na formulação, planejamento, avaliação e controle de programas de saúde do trabalhador;

III - assegurar às CIPAs, às comissões de saúde e aos sindicatos de trabalhadores a participação nos atos de fiscalizaçāo, avaliação e pesquisa referentes ao ambiente de trabalho ou à saúde, bem como garantir acessos aos resultados obtidos;

IV - assegurar ao trabalhador em condições de risco grave ou iminente no local de trabalho a interrupção de suas atividades, sem prejuizo de quaisquer direitos, até a eliminação do risco;

V - assegurar aos sindicatos o direito de requerer ao órgão competente do Serviço de Vigilância Sanitária e Epidemiológica a interdição de máquinas, de parte ou de todo o ambiente de trabalho, quando houver exposiçāo a risco iminente para a vida ou saúde dos trabalhadores e da população, com imediata ação do poder público competente;

VI - considerar o conhecimento do trabalhador como tecnicamente fundamental para o levantamento das áreas de risco e dos danos à saúde: 
VII - estabelecer normas técnicas para a proteção da saúde no trabalho, da mulher no período de gestação, do menor e dos portadores de deficiência; e

VIII - considerar preceitos e recomendações dos organismos internacionais do trabalho, na elaboração de normas técnicas especificas.

Artigo 32 - É dever da autoridade sanitária competente indicar e obrigação do empregador adotar todas as medidas necessárias para a plena correção de irregularidades nos ambientes de trabalho, observados os seguintes niveis de prioridades:

1- eliminação das fontes de riscos;

II - medidas de controle diretamente na fonte;

III - medidas de controle no ambiente de trabalho; e

IV - utilização de equipamentos de proteção individual, que somente deverá ser permitida nas situações de emergência ou nos casos especificos em que for a única possibilidade de proteção, e dentro do prazo estabelecido no cronograma de implantação das medidas de proteção coletiva.

\section{CAPITULO II}

Estruturação das Atividades e da Organização do Trabalho SECÃO I

Dos Riscos no Processo de Produção

Artigo 33 - O transporte, a movimentação, o manuseio e o armazenamento de materiais, o transporte de pessoas, os veículos e os equipamentos usados nestas operaçōes, deverão obedecer a critérios estabelecidos em normas técnicas, que preservem a saúde do trabalhador.

Artigo 34 - A fabricação, importação, venda, locação, instalação, operação e manutenção de máquinas e equipamentos deverão obedecer a critérios estabelecidos em normas técnicas, que preservem a saúde do trabalhador. 
Artigo 35 - As empresas deverão manter sob controle os fatores ambientais de risco à saúde do trabalhador, como ruído, iluminação, calor, frio, umidade, radiações, agentes químicos, pressões hiperbáricas e outros de interesse da saúde, dentro dos critérios estabelecidos em normas técnicas.

Artigo 36 - A organização do trabalho deverá adequar-se às condições psicofisiológicas e ergonômicas dos trabalhadores, tendo em vista as possiveis repercussões negativas sobre a saúde, quer diretamente através dos fatores que a caracterizam, quer pela potencialização dos riscos de natureza física, química ou biológica, presentes no processo de produção, devendo ser objeto de normas técnicas.

Um dos entrevistados, assim se expressou sobre o arcabouço jurídico da Vigilância aos Ambientes de Trabalho no Município:

"O processo de municipalização da vigilância começou em 96 e agora que começou a ter autoridade sanitária para entrar nas empresas. A ação de vigilância sanitária, propriamente, ela tem um ano. Definimos que o primeiro tipo de problemas a ser enfrentado era construir todo o aparato jurídico, era necessário também construir um roteiro de inspeção que tivesse esse viés do Código Sanitário, não era mais trabalhar por NRs, como era a ação da saúde do trabalhador, trabalhar por demanda externa do Ministério Público e agora estamos trabalhando por critério epidemiológico e com um instrumento totalmente da saúde que é o Código Sanitário."

Outro entrevistado, ao ser perguntado se fazia uso do Código Sanitário do Estado, assim se expressou:

"Sim. Nós tínhamos uma proposta de legislação municipal, do Código de Postura, mas parou na Câmara e não foi aprovado. Seguimos as NRs também. Usamos Termos de Notificação, Auto de 
Infração, a gente usa esse material, mas baseado no conhecimento técnico que nós temos, junto com os técnicos da VISA."

Apenas um dos cinco municipios estudados ainda não tem legislação própria que permita a realização de ações de vigilância dos ambientes de trabalho, sendo que o Projeto de Lei que adota o Código Sanitário do Estado ainda se encontra na Câmara dos Vereadores aguardando aprovação. Enquanto não é aprovado, o Programa de Saúde do Trabalhador realiza vigilância dos ambientes de trabalho através do Ministério Público, como explica um dos entrevistados:

"Nós participamos da ação e da audiência com a empresa, como Assistente Técnico do Ministério Público, mas quem comanda isso é o Ministério Público, pelo fato de não termos poder de policia."

O que se denota das informações colhidas junto aos municipios e o estudo da bibliografia é que o arcabouço jurídico para a realização de ações de vigilância nos ambientes de trabalho é dado, inicialmente pela Constituição Federal. A atribuição dada pela Constituição ao Municipio, de legislar sobre proteção e defesa da saúde e o papel de legislar sobre todos os assuntos de interesse local, onde também se inclui a saúde, é a base legal inicial para a conformação da legalidade para os atos de vigilância dos ambientes e processos de trabalho.

A Constituição Estadual e a Lei $9.505 / 99$ (SÃO PAULO, 1999) também atribuem às esferas do SUS essa prerrogativa. O Código Sanitário do Estado (SÃO PAULO, 1998), também no caso de São Paulo e de outros estados que possuam legislações semelhantes, pode ser adotado pelo Municipio, através de Lei Municipal específica e a partir daí, passam a ser utilizados os instrumentos do Código para fins de processamento legal das ações de vigilància, como prazos, multas, taxas, enquadramentos e outrus. 
O Município pode também adotar um Código de Posturas próprio e nesse caso incluir não só as questōes relacionadas à Saúde do Trabalhador, mas também outras de interesse local, como obras e edificaçōes, utilização das vias públicas, horários e condições de funcionamento de estabelecimentos e outros assuntos. Porém, no caso especial da Saúde do Trabalhador, não foi verificada critica substancial ao Código Sanitário do Estado de São Paulo, que obrigasse a se sugerir a elaboração de um Código Municipal próprio. O Código Sanitário existente se enquadra perfeitamente às necessidades da equipe de Vigilância em Saúde do Trabalhador para a execução de suas ações. 


\subsection{Vigilância dos Ambientes e Processos de Trabalho - Concepção e Prática}

A vigilância em saúde do trabalhador, enquanto campo de atuação, distingue-se da vigilância em saúde em geral e de outras disciplinas no campo das relações entre saúde e trabalho por delimitar como seu objeto específico a investigação e intervenção na relaçăo do processo de trabalho com a saúde. Na prática, entretanto, essa concepção não está ainda incorporada em seu sentido amplo, dados sua fragmentação e o pequeno grau de articulação existente entre os componentes diretamente envolvidos nessa relação, a despeito de tentativas de integração interministerial em nivel nacional, da institucionalização de instâncias articuladoras regionais e mesmo de ações locais, como as observadas, por exemplo, no Programa de Saúde dos Trabalhadores da Zona Norte de São Paulo (HUET MACHADO, 1997).

As açōes de vigilância em saúde do trabalhador são influenciadas mais diretamente pelas contribuições da medicina social latino-americana e da experiência italiana de reforma sanitária, que enfatizam algumas características e princípios norteadores dessas ações. Cabe ressaltar as seguintes concepções do pensamento da medicina social latino-americana:

1. a determinação social da saúde;

2. a relativização de métodos quantitativos na análise da associação entre causa e efeito;

3. a integração de diferentes disciplinas em torno da discussão da saúde;

4. o desenvolvimento de práticas e gestões participativas em saúde; 
5. a compreensão da dinâmica entre sujeito individual e coletivo.

Introduzir organizadamente a intervenção nos ambientes de trabalho e recuperar o trabalhador adoecido na agenda dos serviços públicos não compreendem de maneira alguma questões apenas técnicas (CEREST/SP, 1996).

A relaçăo saúde-trabalho é permeada por conflitos e interesses de diversos atores (trabalhadores, sindicatos, empresários, profissionais de saúde e segurança, população geral). Cabe ao poder público o papel fundamental de mediar negociações com o objetivo de proteger a saúde e segurança dos trabalhadores, buscando a colaboração da sociedade e do empresariado e sindicatos em particular. Significa auxiliar no rompimento da lógica do lucro acima de tudo, do oportunismo e do corporativismo, em prol da luta pela preservaçăo da integridade do trabalhador brasileiro. Mais especificamente, significa buscar negociaçōes entre as centrais sindicais, sindicatos de forma geral, associaçóes de portadores de doenças profissionais, entidades patronais como FIESP, CIESP, FENABAN e sindicatos, entidades de classe (sindicatos das categorias profissionais como médicos, psicólogos, servidores públicos etc).

Tradicionalmente, as atividades de conhecimento da situação de saúde têm sido separadas daquelas que visam a intervir para controlar e prevenir os agravos e as condições que os geram, Essa dicotomia encontrase também presente nas ações dos serviços públicos dirigidas à saúde do trabalhador, o que tem merecido criticas de profissionais que atuam nesses serviços, quer por motivos técnicos, quer por motivos políticos (SATO, 1997)

Em termos metodológicos, as ações de vigilância de saúde do trabalhador, além de sistemáticas, estabelecem, em relação a cada caso, 
um processo especifico, construindo a dimensão temporal intrínseca a cada ação de vigilância (HUET MACHADO, 1997). Essa é desencadeada em etapas, num processo de aproximação sucessiva, com aprofundamento e abrangência cada vez maiores, ou seja, grupos de risco são inicialmente delimitados a partir de informações gerenciais e por meio da articulação das açōes de intervenção, investigação e dos serviços de atenção à saúde. São realizadas avaliaçōes em que a heterogeneidade dos grupos homogêneos de risco é evidenciada e motiva novas estratificações. Paralelamente, estabelece-se um processo de negociação das melhorias das condiçōes de trabalho, e as intervençōes propostas nesse âmbito são avaliadas por indicadores sociais, tecnológicos e epidemiológicos. Levam-se em conta as condiçōes tecnológicas da própria empresa, o estabelecimento de prazos e metas para as medidas a serem adotadas. Portanto, embora o periodo previsto para a intervenção seja virtualmente ilimitado, o estabelecimento de etapas com metas a serem cumpridas confere racionalidade e visibilidade ao processo de vigilância.

De acordo com FADEL DE VASCONCELLOS e RIBEIRO (1997), a estratégia adotada pelo Ministério do Trabalho, órgão tradicionalmente responsável pela fiscalização dos ambientes de trabalho no Brasil, caracteriza-se por atividades em que se destacam intervenções:

1. Pontuais e aleatórias - uma vez que atendem apenas às demandas registradas na forma de processo administrativo;

2. Unidisciplinares - pois adotam como método de trabalho a fiscalização onde cada profissional (médico, engenheiro e agente de higiene e segurança) efetua inspeções isoladamente; 
3. Rigidas - pois se limitam ao check-list das normas de segurança e às punições pré-estabelecidas cartorialmente - multa, embargo ou interdição;

4. Sujeitas à corrupção - pela atividade isolada do fiscal e pela falta de transparência e controle de sua ação;

5. Punitivas - ao se limitarem a aplicar as penalidades previstas na lei não garantem a correção dos problemas identificados, tampouco a mudança da política da Empresa no tocante à segurança e à saúde do trabalhador;

6. Restritas - por fiscalizarem o cumprimento da legislação federal Normas Regulamentadoras, Lei 6514/Portaria 3214, ainda que a legislação estadual supere a federal em abrangência e especificidade para os problemas do Estado em questão;

7. Limitadas em sua abrangência - ao intervirem em uma única Empresa não oferecem garantias de mudanças em qualquer outra Empresa do mesmo setor de produção;

8. Excludentes - pela não participação dos trabalhadores, seja no ato da fiscalização, seja no resultado das inspeções, não estão sujeitas ao Controle Social;

9. Não Evolutivas - por estarem restritas às Normas, são incapazes de lidar com situaçōes não previstas na letra da lei, que poderiam subsidiar o próprio aperfeiçoamento normativo.

O MINISTÉRIO DA SAÚDE (1998-a) publicou a Portaria que aprova a Instrução Normativa de Vigilância em Saúde do Trabalhador no SUS, com a 
finalidade de definir procedimentos básicos para o desenvolvimento dessas ações. Há nesse texto, uma série de recomendações para a implementação da Vigilância dos Ambientes de Trabalho, dentro dos princípios do SUS. A Portaria encontra-se, na sua íntegra, no Anexo 2.

Essa Instrução Normativa calca-se no modelo epidemiológico de pesquisa dos agravos, nos diversos niveis da relação entre o trabalho e a saúde, agregando ao universo da avaliaçăo e análise a capacidade imediata da intervenção sobre os fatores determinantes dos danos à saúde.

Um dos entrevistados explicou a forma que são realizadas as ações em seu Municipio:

"Entendemos que era necessário trabalhar com algo que fosse importante e que pudesse gerar um impacto. Então, escolhemos esmagamentos e amputações como prioridade, num primeiro momento. Pela análise de gravidade, quando a gente foi olhar os principais tipos de lesões, vimos que amputações, esmagamentos e fraturas eram as principais. Escolhida uma lista de empresas a serem inspecionadas, nós montamos a equipe e formamos o nosso pessoal dentro desse ambiente jurídico-institucional novo que é trabalhar com o código sanitário, todo mundo tinha uma prática de trabalhar com a NR, trabalhar com o Ministério Público e passou-se a essa prática de trabalhar com o Código Sanitário.

Fizemos um grupo grande, chegou a ter até três médicos em uma ação, escolhemos empresas de médio porte, que aqui é grande, pois a cidade tem empresas pequenas e de porte médio, e fizemos a aplicação do roteiro. Na Empresa, não tivemos problemas para entrar, apesar de ser coisa nova na cidade, nos identificamos como Prefeitura, falando que era a Vigilância municipalizada, as pessoas 
aceitavam a nossa entrada e faziamos uma inspeção, primeiro de fluxograma de matéria prima e de saída de material acabado e do refugo do processo produtivo e depois, a partir do desenho desse fluxograma, a gente passava a seguir todo o processo produtivo, desde a entrada do material e fazíamos a inspeção de cada posto de trabalho.

Fazíamos a identificação dos riscos. Cada posto de trabalho era avaliado, estávamos sempre acompanhados por alguma pessoa da CIPA para perguntar, esclarecer, algumas empresas tinha gente do Sindicato, que se identificava e quando a Empresa permitia eles acompanhavam a gente.

Montávamos um relatório bastante estruturado, com indicação de cada uma dessas coisas que eu falei e uma planilha onde estava anotado, de uma forma mais resumida, o que tinha sido encontrado, os principais riscos, quantas pessoas estavam expostas e numa escala de 1 a 4, qual era o grau de prioridade para intervençăo naquela área. Isso era montado e a gente encaminhava uma cópia para a empresa, uma cópia para o vice-presidente da CIPA e uma cópia para o Sindicato, convidando essas pessoas para a apresentação do relatório na Secretaria de Saúde, onde a gente poderia estar discutindo o que nós vimos e o que nós poderiamos estar priorizando para intervenção.

A partir dai a Empresa é notificada e esse Termo de Notificação flexibiliza um pouco o que o Código Sanitário determina, o Auto de Infração e o Auto de Imposição de Penalidade, abrindo um prazo máximo de negociação de 45 dias para adequação. A empresa vem, faz as críticas, nos processos que a gente fez o ano passado, as 
empresas não contestaram os relatórios, não disseram que era falso, que não existia e tal, elas aceitaram.

A dificuldade começava na hora que tinha que negociar mudanças, em relação a prazos, elas aceitavam o prazo inicial de 45 dias e a partir daí a gente ia para um retorno com a empresa para fazer a revisão. Muitos pontos tinham sido solucionados mas aqueles mais criticos, aqueles que a gente já sabia que ia ser mais dificil, questão de ruido, principalmente, alguns de proteção de máquinas, mais caros, mais complexos e a partir daí, a gente já começava um fluxo do Código Sanitário que é auto de infração e passados os 15 dias, a resposta da empresa, formal, por escrito, e no caso da empresa se manter, não fazer a adequação, a gente faz o Auto de Imposição de Penalidade."

No Estado de São Paulo, através da Resolução SS-196, de 29 de dezembro de 1998, (SÃO PAULO, 1998 -b) foram padronizados Roteiros e Guias de Inspeção em Vigilância Sanitária, no qual se inclui a Ficha Preliminar de Análise de Riscos Ocupacionais, o qual se constitui num importante roteiro para a avaliação de um local de trabalho.

O Ministério Público do Estado de São Paulo também tem um roteiro de inspeção, mais voltado para o enquadramento legal dos problemas de saúde do trabalhador. Um dos municípios estudados elaborou um roteiro de inspeção a partir desses dois instrumentos, no qual, ao final, ficam elencados os principais problemas encontrados, sua gradação de importância para a saúde e a priorização que deverá ser dada para a solução dos problemas. Esse roteiro, após estar preenchido, é entregue a título de relatório aos atores envolvidos e serve de base para a negociação da intervenção a ser realizada no ambiente de trabalho. 
Todos os municipios estudados relataram experiências exitosas no que toca a modificações de ambiente e de processo produtivo em beneficio de melhores condições de trabalho. 


\subsection{Financiamento das Ações de Saúde do Trabalhador no}

\section{Municipio}

No que se refere às receitas municipais, a Constituição Federal de 1988 aumentou a participação dos municípios nas receitas federais e estaduais definidas no texto constitucional e passou para quatro os impostos municipais, que passaram a ser incidentes sobre:

1. propriedade predial e territorial urbana;

2. transmissão intervivos, a qualquer título, por ato oneroso, de bens imóveis;

3. venda a varejo de combustíveis líquidos e gasosos, exceto óleo diesel (imposto extinto em 1996)

4. os serviços de qualquer natureza, definidos em lei complementar e que são mais de 100 (LORDELLO DE MELLO, 2001).

O Fundo de Participação dos Municípios teve seus valores aumentados de $20 \%$, em 1988 , para $22,5 \%$, em 1993 , e os critérios de distribuição são os mesmos. A participação dos municípios no Imposto sobre Circulação de Mercadorias e Serviços (estadual) foi elevado de $20 \%$ para $25 \%$.

A Lei 8.212/91 (BRASIL, 1991) regulamenta o Seguro de Acidentes do Trabalho - SAT - que se destina ao financiamento da Aposentadoria Especial e dos benefícios previdenciários concedidos em razão do grau de incidência de incapacidade laborativa decorrente dos riscos ambientais do trabalho. De acordo com o grau de risco, poderá ser constituido por $1 \%, 2 \%$ ou $3 \%$ da folha de pagamentos da Empresa, ou seja, sobre o total das 
remunerações pagas ou creditadas, no decorrer do mês, aos segurados empregados e trabalhadores avulsos.

Portanto, o SAT, a partir da edição desta Lei, deixou de custear as atividades de proteção, promoção, recuperação e reabilitação da saúde dos trabalhadores, passando a fazê-lo apenas quanto aos benefícios previdenciários.

A Portaria Interministerial MPAS/MS $n^{\circ} 14$, de 13 de fevereiro de 1996 (BRASIL, 1996) resolveu que para co-participar dos gastos do SUS relativos à assistência ao trabalhador, o Ministério da Previdência e Assistência Social transferirá, mensalmente, ao Ministério da Saúde, recursos oriundos da arrecadação do SAT, de acordo com crédito orçamentário devidamente aprovado.

Essa mesma Portaria estabeleceu o início do PIAT - Programa Integrado de Assistência ao Acidentado do Trabalho - através da organização da oferta de atendimento hospitalar de urgência e emergência, incluindo internação ao trabalhador acometido de doença profissional ou vítima de acidente do trabalho. Estabeleceu, também, a divulgação aos organismos interessados, à população em geral e, especialmente, às entidades representativas dos trabalhadores e dos empregadores, a lista dos hospitais integrantes do PIAT, definida em cada estado sob a responsabilidade do Secretário Estadual e dos Secretários Municipais de Saúde, com a recomendaçăo de que, em caso de acidente do trabalho, estes hospitais sejam procurados preferencialmente.

Essa Portaria estabeleceu ainda, a atribuição de remuneração diferenciada, através de sistemática a ser estabelecida em ato normativo da Secretaria de Assistência à Saúde do MS, aos procedimentos realizados em casos de acidente do trabalho. 
Essa Portaria se baseou em documento elaborado pelo Ministério da Saúde (1995) que contabilizou os recursos financeiros gastos com o atendimento de trabalhadores vitimados por acidentes e doenças do trabalho e que propôs que uma parcela dos recursos oriundos da arrecadação do SAT deve ser destinada ao financiamento das ações relacionadas à saúde dos trabalhadores no âmbito do SUS.

No entanto, a remuneraçăo diferenciada para 0 atendimento aos casos de acidente do trabalho ainda não está sendo praticada.

A NOST (MINISTÉRIO DA SAÚDE, 1998) estabelece que

"a organização de unidades especializadas de referência em Saúde do Trabalhador, o estímulo à implementação de unidades no Municipio, na região ou em forma de consórcio, e o registro de $100 \%$ dos casos atendidos de acidentes de trabalho e agravos decorrentes do processo de trabalho, comporăo o Indice de Valorização de Resultados (IVR), de acordo com os critérios a serem definidos pela Comissão Intergestores Tripartite, e a ser estabelecido em portaria do Ministério da Saúde".

e prossegue:

"A implementação do financiamento das ações de saúde do trabalhador consiste na garantia do recebimento dos recursos por meio das fontes de transferências, já constituídas legalmente em cada esfera de governo e na definição de mecanismos que garantam que os recursos provenientes destas fontes sejam aplicados no desenvolvimento das ações de saúde do trabalhador estabelecidas nos planos de saúde." 
No entanto, o Indice de Valorização dos Resultados para o estimulo ao desenvolvimento das ações de Saúde do Trabalhador não se encontra ainda regulamentado e os Municipios deverão aplicar recursos próprios para a implantação desses programas, registrando os atendimentos realizados pela equipe como atendimentos de Clínica Médica, no SIASSUS e os atendimentos em saúde do trabalhador que geram $\mathrm{AlH}$, de acordo com a Portaria 1.969/2001 (MINISTÉRIO DA SAÚDE, 2001 c), a qual no entanto não gera qualquer contrapartida financeira ao prestador, constituindo-se apenas em um instrumento de vigilância epidemiológica.

Nenhum dos municipios estudados tem recursos destinados especificamente para a Saúde do Trabalhador. Alguns municipios encaminharam projetos de financiamento para o Ministério da Saúde e aguardam a aprovação das propostas. 


\subsection{Institucionalização dos Programas de Saúde do Trabalhador}

Segundo ROGERS (1983), a institucionalização de um programa é a etapa final do processo de sua difusão. A institucionalização aparece quando um programa se transforma em parte integrante do trabalho da organização.

Depois de adotar o novo programa, a organização o implanta e o mantém se a fase de implantação transcorreu em sucesso. A descrição desse processo foi se refinando ao curso dos anos, através do detalhamento dos principios que transcorrem em cada uma das etapas. Desta forma, a institucionalização é geralmente definida como sendo a integração de um programa de promoção da saúde na estrutura de uma organização. Quando um programa é institucionalizado, ele faz parte da missão, do organograma da organização e do orçamento que são ali alocados a cada ano (RENAUD e cols., 1997).

BRACHT e cols. (1994) especificam que a apropriação de um programa é a resultante da participação dos cidadãos que se traduz por uma implicação real no planejamento, implantação e formulação de recomendações visando a institucionalização do programa a longo termo. Outra variável que pode intervir igualmente nesse processo é o nivel de colaboração dos diferentes atores implicados no programa de promoção da saúde. $O$ interesse de utilizar este modelo reside no fato de que se pode, desde 0 inicio da fase de implantação, interpor ações que estimularão 0 sentimento de apropriação depois da incorporação do programa na organização, favorecendo assim, a sua institucionalização.

Segundo FOREST (s/d), achar que toda ação pública deveria ser concebida como um processo aberto, conduzido de maneira a informar, 
escutar e a levar em conta os cidadãos não é puramente uma orientação ideológica, mas uma questão de eficácia. O consentimento e a iniciativa dos cidadãos são condições necessárias ao alcance dos objetivos governamentais e, por isso, devem ter sua parte na definição e execução das prioridades públicas.

Várias iniciativas municipais em Saúde do Trabalhador começam com a participação dos principais atores envolvidos na área, como é o caso deste relato de um dos entrevistados:

"As primeiras discussões para montar o PST ocorreram em setembro de 1995, quando deu início o processo de discussão. Quem participou desse processo foram todas as entidades que fazem interface com o PST, todos os sindicatos, universidade, DRT, INSS, Ministério Público, fizemos uma grande discussão sobre a viabilidade de implantar o PST aqui e desse evento grande saiu um grupo de trabalho menor com representantes de cada área para montar um projeto propondo a implantação do PST na cidade. Esse grupo de trabalho atuou durante bastante tempo, escreveu o Projeto prevendo a implantação, esse Projeto foi aprovado pelo Conselho Municipal de Saúde e depois foi encaminhado à Secretaria de Estado da Saúde, solicitando uma parceria."

Em outro município, também, o Programa de Saúde do Trabalhador iniciou-se a partir de seminários com o movimento sindical e técnicos da área que discutiram que orientação teria o Programa e como seria organizado.

Na implantação de um Programa Municipal de Saúde do Trabalhador é importante contemplar a participação dos usuários, no caso os trabalhadores, organizados em sindicatos, associações ou comissões; na 
elaboração, no planejamento, na execução e na avaliação do Programa, o que gera um sentimento de apropriação e estimula a incorporação do programa ao Sistema de Saúde.

Cabe ao gestor, com uma grande sensibilidade política, verificar no espectro político de seu Município, como se organizam as forças representativas dos trabalhadores e quais organizações contemplam todas as correntes de pensamento, inclusive aquelas que não estão organizadas em Centrais, Federações e Sindicatos. Contemplar todo o espectro político do movimento sindical, muitas vezes não é tarefa fácil. Entretanto, o esforço realizado será compensado com o envolvimento e a participação democrática de todas as correntes de pensamento no processo de implantação do Programa, o que o fortalecerá. 


\subsection{Participação Popular em Saúde do Trabalhador}

A participação popular traz para o processo organizacional elementos muito concretos (KLISKSBERG, 2001). Entre eles, a concepção dos projetos em conjunto com a comunidade permite que ela incorpore a ele suas verdadeiras prioridades. Sua intervenção na gestão do projeto dá-lhe uma força singular. Ao sentir-se dona real do projeto, a comunidade traz iniciativas, idéias, preocupa-se com cada detalhe de seu funcionamento. Sua integração ao acompanhamento e à avaliaçăo permite que o projeto tenha um "pólo" permanente da realidade. Os beneficiados estarão dizendo continuamente em que medida se compõem ou não os objetivos fixados e que correções deveriam ser introduzidas.

A participação popular assegura também a transparência do projeto. Talvez, acima de todas as coisas, o "ownership" da comunidade vá gerando um fortalecimento da mesma. Ela aprende, cresce, eleva sua auto-estima e se criam bases para a sustentabilidade do projeto quando for retirada a ajuda externa.

No extenso trabalho de pesquisa sobre 0 assunto realizado por MENENDEZ (1998), verifica-se que há duas concepções do que venha a ser participação popular em saúde. Uma, que se desenvolveu a partir da década de 50 e propõe a capacitação da população para que resolva os problemas de saúde com seus próprios esforços e consiga uma melhoria de sua qualidade de vida. Propõe a estimulação, a mobilização e a assessoria aos líderes da comunidade e à vizinhança para que se desenvolva a ajuda mútua.

Uma outra concepção, que se desenvolveu a partir dos anos 70 é a que considera a participação popular como um processo que permite 0 desenvolvimento da população, incorporando sua capacidade criadora, 
expressando suas necessidades e demandas, defendendo seus interesses, lutando por objetivos definidos, envolvendo a comunidade em seu próprio desenvolvimento e participando do controle compartilhado das decisões. É esta segunda concepção que está sendo tratada neste texto, a qual em alguns trabalhos pesquisados é chamada de 'controle social', não se encontrando referências a diferentes concepções entre o que se intitula 'participaçáo popular' e o que se denomina 'controle social'. No texto constitucional é feita referência à 'participação da comunidade'.

A instituição de Conselhos de Saúde é uma novidade no contexto jurídico do País, desde o advento da Lei Orgânica da Saúde, que Ihes delineia o perfil de modo assistemático, mas perfeitamente de acordo com a Constituição Federal vigente (DODGE, 1997). De fato, a natureza jurídica e as atribuições que thes são próprias não estão dispostas de modo claro e coordenado entre si, de forma a permitir imediata compreensão de todas as características destas entidades.

Ainda segundo a Autora, os Conselhos de Saúde são órgãos do SUS, pelo que não têm personalidade jurídica própria, nem capacidade de estar em juízo. Integram a União, o Estado ou o Município, a depender da esfera em que se situem. São instituições permanentes, na perspectiva de que devem ser instalados e ter atuação regular, não esporádica ou eventual.

Têm função deliberativa quando sua atribuição for diretiva ${ }^{8}$, mas não sempre, pois a depender da matéria sua função será ora consultiva ora meramente fiscalizatória ${ }^{9}$, segundo o que for determinado em lei. Tudo o que for estabelecido em legislação infraconstitucional como atribuição de Conselho de Saúde só é válido se for compativel com a lei ordinária e a

\footnotetext{
${ }^{8}$ Lei n' $8.080 / 90$, art. 37

${ }^{9}$ Lei n 8.080/90, art. 33
} 
Constituição. Todas estas atribuições situam-se, no entanto, no contexto do controle social que se exerce no âmbito do SUS.

DODGE (1997) elenca as atribuições dos Conselhos de Saúde, como órgão deliberativo, consultivo ou fiscalizadores da seguinte forma:

"Os Conselhos de Saúde, no âmbito de sua respectiva esfera de atuação, atuam corno órgão deliberativo sobre:

- a elaboração da proposta orçamentária em cada nivel de governo; 10

- a formulação de estratégias da politica de saúde; ${ }^{11}$

- diretrizes a serem observadas na elaboração dos planos de saúde, em função das características epidemiológicas e da organização dos serviços em cada.jurisdição administrativa; ${ }^{12}$

- cronograma de transferência de recursos financeiros aos estados, Distrito Federal e municipios, consignados ao SUS; ${ }^{13}$

- critérios e valores para remuneração de serviços e os parâmetros de cobertura assistencial, a serem estabelecidos pela direção nacional do

SUS; ${ }^{14}$

\footnotetext{
${ }^{10}$ Constituiçăo Federal, art. 195- $\$ 2$ ' e Lei n" 8.080190, art. 36

' 'Lei n' 8.080/90, art. 36; Lei n' 8.142/90, art. $1^{\circ}-\$ 2^{\prime}$ e Decreto n' 99.438/90, art. $1^{\circ}-1$ )

${ }^{12}$ Lei n' 8.080/90, art. 3' , e Decreto n' 99.438/90, art. $1^{\circ}$ - II

${ }^{13}$ Lei $n^{\circ} 8.142 / 90$, art. $1^{\circ}$ - $\S 2^{\circ}$ e Decreto $n^{\circ} 99.438 / 90$, art. $1^{\circ}$ - III

${ }^{14}$ Lei $n^{\circ} 8.080 / 90$. art. 26 e Decreto $99.438 / 90$, art. $1^{\circ}$ - IV
} 
- convocar extraordinariamente a Conferência de Saúde para avaliar a situação de saúde e propor as diretrizes para a formulação da política de saúde nos níveis correspondentes; ${ }^{15}$

Os Conselhos de Saúde atuam como órgãos consultivos:

- ao assistir a autoridade local ou federal no processo de planejamento do SUS; ${ }^{16}$

- ao propor critérios para a definição de padrões e parâmetros assistenciais; ${ }^{17}$

- ao acompanhar o processo de desenvolvimento e incorporação científica e tecnológica na área de saúde, visando a observação de padrões éticos compatíveis com o desenvolvimento sociocultural do país; ${ }^{18}$

- na criação de novos cursos de ensino superior na área de saúde. ${ }^{19}$

Os Conselhos de Saúde atuam como órgãos de fiscalização quanto à:

- movimentação, em si, dos recursos financeiros do SUS no âmbito de sua respectiva atuação; ${ }^{20}$

- execução da política de saúde da instância correspondente, inclusive nos aspectos econômico-financeiros; ${ }^{21}$

\footnotetext{
${ }^{15}$ Lei $n^{\circ} 8.142 / 90$, art. $1^{\circ}$ - $\S 1^{0}$;

${ }^{16}$ Lei $n^{\circ} 8.080 / 90$, art. 36)

${ }^{17}$ Decreto $n^{\circ} 99.438 / 90$, art. $1^{\circ}-\mathrm{V}$

${ }^{18}$ Decreto $^{\circ} 99.438 / 90$, art. 10-VII

${ }^{19}$ Decreto $n^{\circ} 99.438 / 90$, art. $1^{\circ}$-VIII

${ }^{20}$ Lei $n^{\circ} 8.080 / 90$, art. 33

${ }^{21}$ Lei $n^{\circ} 8.142 / 90$, art. $1^{\circ}-\S 2^{\circ}$
} 
- acompanhamento e controle da atuação do setor privado da área da saúde, credenciado mediante contrato ou convênio. ${ }^{22,}$

Estas referências não esgotam as atribuiçōes, mas são exemplificativas da sua diversidade.

DODGE (1997) ainda complementa seu estudo sobre as atribuições deliberativa, consultiva e fiscalizatória dos Conselhos de Saúde:

"As conseqüências decorrentes da natureza de tais funções são diferentes. A atuação de caráter deliberativo importa, por exemplo, em que suas decisões devam ser homologadas pelo chefe do poder legalmente constituído em cada esfera de governo, visto ser esta a autoridade com poder hierárquico sobre os demais funcionários da instituição $e$, portanto, quem lhes determina a execução das decisões tomadas pelo Conselho. ${ }^{23}$

A função fiscalizadora gera para o Conselho o dever de apurar ilicitos e irregularidades e de levar tais fatos ao conhecimento da autoridade administrativa, do sistema de auditoria, do sistema de controle interno, do Tribunal de Contas ou do Ministério Público, conforme o caso, para as providências cabiveis.

A função consultiva resume-se a externar a posição do Conselho quanto ao objeto da consulta, mas tem importância decorrente da legitimidade que a Constituição Ihe dá, por ser órgão cuja composição deve ser representativa da comunidade. 
Os Conselhos de Saúde não são órgãos executivos porque a direção do SUS é exercida, em cada esfera de governo, pelo Ministério da Saúde ou pela secretaria de saúde estadual ou municipal, ou órgão equivalente. ${ }^{24}$ Não são substitutos dos órgãos de controle interno ou dos Tribunais de Contas.

Assim, os Conselhos de Saúde manifestam-se por meio de resoluções, quando sua atribuição for deliberativa; por meio de recomendações ou moções, quando sua função for consultiva; por meio de comunicação ou representação, quando sua função for fiscalizadora - sendo-Ihes facultado solicitar informações a entidades públicas e privadas para 0 desempenho de qualquer destas atribuições."

O Controle Social da Atividade Produtiva constitui uma premissa básica para a discussăo das ações de Vigilância em Saúde do Trabalhador, uma vez que o modelo tradicional, não incorporador da participação social em suas estratégias de ação, não foi capaz de resolver as questões de risco à saúde nos ambientes de trabalho (FADEL DE VASCONCELOS e RIBEIRO, 1997).

Para concretizar o Controle Social da Atividade Produtiva, no que diz respeito à saúde, o Programa de Saúde do Trabalhador deve ser capaz de ajustar-se, no seu cotidiano, à participação do movimento sindical em todas as esferas de ação, nos seus planejamento, execução e avaliação.

As atividades da Vigilância em Saúde do Trabalhador, sob a ótica do Controle Social, pressupõem, como fundamento, que se ultrapasse a esfera de consulta ao movimento social e realmente o incorpore nas ações por dentro da máquina do Estado.

${ }^{24}$ Lei $n^{\circ} 8.080 / 90$, art. $9^{\circ}$ 
A NOST (MINISTÉRIO DA SAÚDE, 1998) recomenda a instituição de Comissão Intersetorial de Saúde do Trabalhador, com a participação de entidades que tenham interfaces com a área de saúde do trabalhador, subordinada ao Conselho Municipal de Saúde, com a finalidade de assessorá-lo na definição das políticas, no estabelecimento de prioridades e no acompanhamento e avaliação das ações de saúde do trabalhador.

Também a Instruçăo Normativa de Vigilância em Saúde do Trabalhador, considera como princípio o Controle Social, entendendo-o como a incorporação dos trabalhadores e das suas organizações, principalmente as sindicais, em todas as etapas da vigilância em saúde do trabalhador, compreendendo sua participação na identificação das demandas, no planejamento, no estabelecimento de prioridades e adoção de estratégias, na execução das ações, no seu acompanhamento e avaliação e no controle da aplicação dos recursos.

Mais à frente, a Instrução Normativa prossegue:

"Recomenda-se a criação de comissão, na forma colegiada, com a participação de trabalhadores, suas organizaçōes sindicais e instituições públicas com responsabilidades em saúde do trabalhador, vinculada organicamente ao SUS e subordinada aos Conselhos Estaduais e Municipais de Saúde, com a finalidade de assessora-lo na definição de políticas, no estabelcimento de diretrizes e prioridades, e no acompanhamento e avaliação da execução das ações de saúde do trabalhador."

Um dos entrevistados, perguntado sobre a criação de uma Comissão Intersetorial de Saúde do Trabalhador assim respondeu: 
"Antes da NOST falar sobre isso, a gente já pensava nessa questão de estar criando um Conselho no Municipio. Em que pese todo o conflito entre capital e trabalho nessa história, acho que ninguém vai dizer que é contra a vida ou que é contra a saúde das pessoas. É um consenso mínimo que a gente tem na sociedade a favor da vida e da saúde. Agora como viabilizar isso diante dos interesses diversos, é o que a gente queria estar discutindo. Precisava conversar com a Previdência, precisava conversar com o Ministério Público. O MP, por exemplo, no início da saúde do trabalhador trouxe uma demanda para a gente, de denúncia de acidentes do trabalho que depois que nós demos resposta para ele, não nos procuraram mais, nunca chegou a um trabalho efetivo. $A$ gente sabia que o MP recebia demanda de sindicatos, da população, mas eles trabalhavam com o Ministério do Trabalho, com a DRT e não trabalhavam com a gente. Com as entidades representativas das empresas é preciso também conversar sobre a questão da modificação dos ambientes, da readaptação. Por exemplo, na hora que a gente fazia uma carta de readaptação para alguém, na hora do retorno a pessoa dizia que tinha levado a carta e o médico de lá, ou o gerente de Recursos Humanos ou o dono da empresa pegou a carta, rasgou e disse que ele iria trabalhar onde ele quisesse. Com a empresa é necessário não só esse tipo de conversa, é necessário ver outros assuntos. Com os sindicatos, é necessário ver que a questão da saúde do trabalhador mobilizou os sindicatos nos últimos anos, então a gente queria trazer também o sindicato para perto. A gente também achou que nessa Comissão Intersetorial era necessário construir uma relação de parceria com o Ministério do Trabalho, trazer a DRT para perto para a gente discutir. Com o Meio Ambiente. Todos esses setores a gente acabou convidando para uma discussão, que a gente chamou de Semana de Saúde do Trabalhador de 1998, chamamos todos esses setores que eu nomeei aqui, mais a 
Secretaria de Desenvolvimento Econômico da Prefeitura. A idéia era discutir o que é a ação intersetorial em saúde do trabalhador e discutir o que é a ação em saúde do trabalhador. Na preparação do seminário, nós mandamos três perguntas para cada uma dessas representações. A primeira era como o seu setor vê a questão da Saúde do Trabalhador, como avalia essa questão? A segunda pergunta era como vê a questão da criação de uma Comissão Intersetorial? E como seu setor poderia contribuir numa ação intersetorial? Foi curioso, pois as respostas foram as mais diversas possiveis, desde aquelas pessoas que disseram, que bom, agora nós vamos unir esforços, vamos resolver a questão da saúde do trabalhador, que é uma visão equivocada, porque a gente falava, não é uma questão de unir esforços, porque os interesses aqui são conflitantes, então não vai unir esforços, o que podemos estar estabelecendo é alguns consensos e estabelecendo alguns parâmetros que são toleráveis e como a gente vai fiscalizar os diversos espaços em que a saúde do trabalhador é abordada, tanto do ponto de vista do local de trabalho, como do serviço de saúde, ou da Previdência, ou das ações que as diferentes instituições venham a fazer, de vigilância, de prevenção."

Depreende-se dos textos e das entrevistas que a participação popular não tem apenas o condão de fazer com que a comunidade se aproprie do programa e favoreça a sua institucionalização, como foi visto no Capitulo anterior. A participação dos trabalhadores em todas as fases do desenvolvimento de um Programa de Saúde do Trabalhador, da elaboração à avaliação, estimula a apreensão pelo serviço do conhecimento do cotidiano do trabalhador, de suas prioridades enquanto grupo social, de seus interesses, de suas demandas, de suas necessidades. 
No entanto, vários aspectos devem ser cuidados para aperfeiçoar e potencializar a participação popular. Um deles é cuidar, no âmbito do espaço institucional, para que a representação dos usuários seja a mais representativa possivel e que o Conselho de Saúde não seja utilizado como canal para angariar privilégios ou favorecimentos de natureza diversa do que a do coletivo.

Outra questão a ser cuidada é que o conselheiro de saúde pouco ou nada conhece da administração pública e o seu trabalho no Conselho será valorizado se vier a ter noções de como se administra um serviço de saúde, para que possa contribuir com maior riqueza. Desta forma, a realização de cursos de capacitação para conselheiros de saúde, que contemplem legislação básica, o funcionamento das finanças e dos gastos públicos, da contratação de recursos humanos e outros assuntos pertinentes, que podem até ser definidos pelo próprio Pleno do Conselho, será de grande valia para o aperfeiçoamento da participação do cidadão. 


\section{DISCUSSÃO E CONCLUSÕES}

A municipalização das ações de saúde do trabalhador vem ocorrendo de forma crescente, desde a promulgação da Constituição Federal em 1988 em que foram definidas as bases do Sistema Único de Saúde, entre eles a descentralização.

Antes mesmo de ser incluida na Constituição a atribuição ao SUS de execução das ações de Saúde do Trabalhador, diversos programas municipais já haviam sido implantados, vinculando-se à Política Nacional de Saúde, e já se legitimavam junto aos sindicatos, universidades, outras áreas de governo que atuam no setor, setores empresariais e técnicos em geral, com o aumento do número de diagnósticos e notificações de doenças profissionais, com as primeiras ações de vigilância dos ambientes de trabalho, com as primeiras experiências de processos de trabalho na área e com as primeiras formulações teóricas sobre o tema.

Muito influenciaram neste início das açōes de Saúde do Trabalhador nos serviços públicos de saúde, o Modelo Operário Italiano e os trabalhos da Medicina Social Latino-americana, que se constituíram na referência teórica conceitual dessa prática, a qual no entanto ainda não está definida completamente, encontrando-se em constante (re)elaboração.

As Normas Operacionais Básicas de 1991, 1993 e 1996 instrumentalizaram o processo de descentralização das ações de saúde para os municípios, passando a estes atribuições de gestão da política de saúde. A quase totalidade dos municípios brasileiros, incorporando $99,7 \%$ da população do País, encontra-se em gestão plena, seja da atenção básica, seja do sistema municipal de saúde. 
No entanto, há autores que, corretamente qualificam esse processo como de desconcentração e não de descentralização, pelo fato de que o governo central mantém o controle e as rédeas do repasse de recursos, como também da natureza, forma e ritmo em que são repassadas. $E$ de que adianta transferir poder para a elaboração de políticas locais de saúde se esta não está acompanhada da transferência adequada de recursos para a implementação dessas políticas? Acresce-se a isto o fato de que o sistema tributário nacional é injusto com os municípios e a carga atribuída a estes, com a municipalização da saúde, ficou extremamente pesada.

A relação dialética existente entre a descentralização e a centralização, na medida em que faz com que um exista em função do outro, faz também com que os entes descentralizados busquem abarcar maior parcela de recursos para poderem executar as açōes a eles atribuídas pela nova fatia de poder, pois esta não vem só, mas sim acompanhada por uma grande porção de responsabilidade com a vida e com a saúde das pessoas. A descentralização da saúde repassa poder para o nível local, mas também repassa novas responsabilidades em todo o campo social.

Com a edição da Lei 8.080/90 (BRASIL, 1990), intitulada Lei Orgânica da Saúde, ficou regulamentado no artigo $6^{\circ}$ o que se encontrava inscrito na Constituição, atribuindo-se ao SUS a implantação de ações de saúde do trabalhador em todas as esferas de governo.

A Norma Operacional de Saúde do Trabalhador - NOST/SUS (MINISTÉRIO DA SAÚDE, 1998) definiu as atribuições e responsabilidades dos municipios nas duas formas de gestão no tocante a essa área de atuação.

A politica de Saúde do Trabalhador a ser implementada no Municipio deve levar em conta que o processo saúde-doença-trabalho é resultante da 
política de desenvolvimento, de emprego, salário, habitação, transporte, segurança pública, educação e outras políticas econômicas e sociais, a maioria delas de atribuição de outras esferas de governo, cabendo ao gestor local quase que tão somente a recuperação do cidadão vitimado por essa política, muito pouco podendo contribuir com a efetiva promoção e proteção da saúde do trabalhador, extremamente dependentes de políticas macro-econômicas.

Deve também o gestor municipal ter bastante claro que outras instituições governamentais ou não, executam ações de atendimento aos trabalhadores e podem contribuir com o seu Programa, de forma sinérgica, como também podem atuar em sentido inverso, com ações antagônicas e dificultadoras do trabalho proposto. O campo da Saúde do Trabalhador é naturalmente conturbado pelo movimento dos trabalhadores por melhores condições de vida e trabalho e pelas ações e reações que esse processo deflagra.

As ações de saúde do trabalhador devem ser organizadas para que se forneça assistência aos trabalhadores, vítimas de acidentes do trabalho, doenças profissionais, ou doenças relacionadas ao trabalho, compreendendo as ações de diagnóstico, estabelecimento do nexo com o trabalho, tratamento e recuperação da saúde, e reabilitação.

É também atribuição do SUS, no âmbito municipal, a realização dos procedimentos visando ao acesso dos trabalhadores segurados pelo Seguro de Acidentes do Trabalho da Previdência Social aos beneficios previstos na legislação, como também a outras formas de Previdência Social, como a dos funcionários públicos. 
Deve-se também, executar as ações de promoção e proteção da saúde, com a vigilância das condições e ambientes de trabalho, incluindo procedimentos de normatização, notificação e imposição de penalidades.

O treinamento e desenvolvimento de pessoal que trabalha na área deve ser previsto e também a implantação de sistema de Informação e educação dos empregadores, trabalhadores e outros setores sociais envolvidos ou interessados no tema

Cabe, portanto, aos municípios que se encontram tanto na forma de gestão plena do sistema de saúde, como os que se encontram na gestão plena da atenção básica da saúde, elaborar uma política de saúde do trabalhador, dando conta das novas responsabilidades sanitárias assumidas com a habilitação.

Para organizar a atenção à saúde dos trabalhadores, há duas grandes correntes em debate: uma delas advoga que as ações devam ser implantadas na rede básica de saúde, cabendo aos médicos clínicos o atendimento aos trabalhadores. Estes clínicos seriam sensibilizados através de treinamento adequado para compreenderem toda a problemática envolvida na intervenção sanitária no processo saúde-doença no trabalho e haveria uma referência em Medicina do Trabalho no Centro de Especialidades para os atendimentos tecnologicamente mais complexos. Da mesma maneira, as ações de vigilância aos ambientes e processos de trabalho seriam realizados pelas equipes de vigilância à saúde treinadas para tal e nas quais estivessem incluidos profissionais especializados nesse tipo de atividade.

Outra corrente preconiza a criação de Centros de Referência em Saúde do Trabalhador que, contraditoriamente, seriam a porta de entrada do sistema, centros estes que estariam voltados única e exclusivamente 
para a assistência e promoção da saúde do trabalhador, bem como para o manejo previdenciário dos agravos.

Apesar da estar incluido ao final da NOST que o Município deverá manter unidade especializada de referência em Saúde do Trabalhador, para facilitar a execução das ações, o que pode criar alguma confusão, em verdade não se afirma que 0 atendimento deverá ser feito exclusivamente nessa unidade especializada, à qual deverá caber a referência, isto é, os atendimentos que não forem possíveis de ser resolvidos nas unidades de atenção básica.

As experiências municipais que ficaram restritas à criação de Centros de Referência em Saúde do Trabalhador, na atualidade manifestam críticas a esse modelo, o qual se transformou numa espécie de gueto de profissionais envolvidos com a área, sem que o tema da atenção a essa parcela da população fosse transferia para toda a rede de atendimento. Houve grande prejuizo principalmente quanto à universalidade e integralidade da atenção.

Desta forma, o modelo proposto para a organização desse serviço é - estabelecimento de ações primárias de Saúde do Trabalhador, que envolvam práticas de promoção e de proteção à saúde, mas também de diagnóstico, tratamento e de manejo previdenciário do caso. Estas açōes serão desenvolvidas nas unidades básicas de saúde através das equipes já instaladas, tornando-se necessária a sensibilização e capacitação dos trabalhadores em saúde para essa nova demanda.

Essas atividades de sensibilização devem levar em conta os preconceitos embutidos no corpo de profissionais, principalmente médicos, de que a Saúde do Trabalhador, ou a Medicina do Trabalho, é uma especialidade complexa e que somente está ao alcance de especialistas. $\dot{E}$ 
necessário aclarar que não se praticará Medicina do Trabalho, mas sim Clínica de Adultos, pois as doenças dos trabalhadores mais prevalentes acometem também pessoas não obrigatoriamente submetidas ao risco no ambiente de trabalho. Caberá ao Clínico, o diagnóstico dessas doenças, 0 estabelecimento do nexo com o trabalho, como relatado pelo trabalhador, e o tratamento, bem como o encaminhamento da pessoa à Previdência Social com a CAT e um relatório médico explicativo da natureza da doença e do tempo provável de afastamento do trabalho, se for o caso.

Nesse sistema, haverá uma referência em Medicina do Trabalho, no Ambulatório de Especialidades, junto ao cardiologista, ao neurologista, ao oftalmologista e outros especialistas, que atenderá os casos referenciados pelas unidades e o assumirá, ou apenas realizará a inter-consulta, contrareferenciando o caso para a unidade básica.

Da mesma forma, quanto à vigilância em saúde do trabalhador, a qual deverá ser instalada na mesma unidade e espaço físico da vigilância sanitária, pois ela é uma de suas modalidades. As ações de vigilância dos ambientes de trabalho serão realizadas pela equipe de vigilância sanitária, podendo-se agregar a esta pessoal especializado, que poderá ser acionado em casos especiais. Pode-se também conformar um Núcleo de Vigilância em Saúde do Trabalhador, mais especializado, mas que atuará em conjunto com as demais áreas da Vigilância, fazendo inspeções conjuntas e utilizando os mesmos processos. Um componente da vigilância não poderá entrar em um local de trabalho para verificar apenas se a comida está contaminada ou as condições de armazenamento dos alimentos está correta, mas também se as condições de trabalho estão adequadas. Da mesma forma, um outro componente não poderá entrar em uma fábrica para verificar um determinado risco denunciado e deixar de lado a fiscalização dos locais de higiene pessoal e de alimentação dos trabalhadores, ou até a 
adequação do processo de fabricação, caso esteja no interior de uma indústria que produza produtos de interesse para a saúde.

Quanto aos recursos humanos necessários à implementação das ações de saúde do trabalhador verifica-se a necessidade da adoção das práticas inter/transdisciplinares. Se em outras áreas esse processo de trabalho é uma meta a ser atingida, na área de saúde e trabalho, torna-se crucial a integração e a atuação conjunta entre as várias disciplinas, pois o trabalho e sua relação com a saúde só podem ser entendidos se houver os olhares do médico, enfermeiro, assistente social, engenheiro, ergonomista, sociólogo, toxicologista, educador, psicólogo, químico, advogado e demais profissionais tradicionalmente ou recentemente ligados à área da saúde.

A atuação transdisciplinar rompe com o caráter de ação conjugada, em que cada membro da equipe "faz a sua parte" isoladamente, superando o simples somatório de conhecimentos técnico-científicos e facultando a todos os membros da equipe a apropriação dos diversos conhecimentos, potencializando-os. Todos devem realizar as atividades de assistência, informação, vigilância dos ambientes, manejo previdenciário e outras, respeitando os limites técnicos de sua atribuição, debatendo as dificuldades e assim multiplicando as possibilidades de intervenção em vez de apenas somá-las.

O desenvolvimento do pessoal para essa nova prática deve ser estabelecido pelo próprio serviço já que a formação profissional, tanto na graduação, como na especialização, com raras exceções, não é voltada para a atuação inter/transdiciplinar.

Essa atividade de capacitação e desenvolvimento de pessoal deve pensar também na quebra dos mitos criados nos profissionais, sobre as relações de poder entre as disciplinas, buscando o sentido da cooperação, 
do questionamento respeitoso, do diálogo entre as disciplinas e também da importância do resgate do saber do trabalhador, o qual muitas vezes é negligenciado ou subestimado. Todas as ações de capacitação e desenvolvimento de pessoal que foram conhecidas, seja através da bibliografia consultada ou por relato pessoal, tiveram bons resultados.

Muitas universidades públicas mantêm cursos de especialização em saúde do trabalhador voltados para as equipes multidisciplinares e que podem ser utilizados nesse processo de formação. Também cursos específicos podem ser programados e parcerias serem realizadas com as unviersidades visando o aprimoramento dos trabalhadores em Saúde do Trabalhador.

Os recursos materiais necessários são os de escritório, de atendimento clínico e o micro-computador para o sistema de informação. A cabine audiométrica, o audiômetro e o impedanciômetro, na medida em que a Perda Auditiva Induzida por Ruído é uma das moléstias ocupacionais mais prevalentes em nosso meio é importante, mas não imprescindivel, pois pode ser feita a opção pelo compartilhamento do serviço fonoaudiológico próprio ou contratado pelo SUS.

Os equipamentos de avaliação ambiental não são essenciais ou imprescindiveis para o Programa Municipal de Saúde do Trabalhador. As inspeções nos locais de trabalho são qualitativas, de reconhecimento de riscos e não de sua avaliação, não sendo obrigatórias as quantificações de concentração de agentes. Deve-se recorrer às avaliações realizadas pelas empresas e cotejá-las com as informações fornecidas pelos trabalhadores e com o reconhecimento do local.

No entanto, se houver recursos financeiros disponiveis, sugere-se a aquisição de um medidor de nível de pressão sonora, ou de um 
equipamento para coleta de gases, levando-se sempre em conta 0 alto custo destes equipamentos, bem como de sua manutenção. Há também a possibilidade de compartilhamento desses equipamentos entre programas próximos.

A informação é elemento essencial para a vigilância em saúde do trabalhador, para a administração e planejamento dos serviços e das ações de assistência e reabilitação, e para gerar conhecimento e consciência crítica sobre os riscos que devem ser enfrentados para a garantia da saúde dos trabalhadores. A construção de um sistema de informação em saúde do trabalhador que produza conhecimentos e que descreva a realidade tornase, portanto, elemento estratégico na definição de uma política de Saúde do Trabalhador.

Não há na atualidade, um sistema de informação nessa área que seja padronizado pelo SUS em qualquer de suas esferas, cabendo a cada Município desenvolver o seu próprio. 0 que se observa, no entanto, é que alguns pressupostos devem ser observados.

Primeiro, quanto ao instrumento de coleta de dados, a CAT não consegue cumprir esse objetivo, pois apenas cerca de $50 \%$ da população urbana encontra-se no mercado formal e regido pela CLT. Assim, um instrumento criado para obter informações sobre os agravos na porta de entrada do sistema é o desejável.

O conhecimento dos denominadores em saúde do trabalhador é um outro problema, na medida em que não existem informações disponiveis. 0 cadastro de empresas com número de funcionários, a RAIS e informações fornecidas por sindicatos de trabalhadores é um dos meios disponiveis. 
Também o sistema de informatização dos dados deve prover informações epidemiológicas que permitam o planejamento, controle e avaliação das ações, havendo várias experiências exitosas neste sentido.

No Brasil, a competência para legislar sobre proteção e defesa da saúde é concorrente, da União, dos Estados e do Distrito Federal e dos Municípios. Isso significa que cabe à Uniăo o estabelecimento de normas gerais sobre $o$ assunto. Aos Estados cabe suplementar a legislação posta pela União. Finalmente, cabe aos Municípios, legislar sobre todos os assuntos de interesse local.

Pode-se afirmar que o Município está duplamente titulado para legislar sobre proteção e defesa da saúde. O primeiro título refere-se à competência para suplementar a legislaçăo federal e a estadual no que couber. $O$ segundo é relativo à predominância do interesse local pela proteção e defesa da saúde como objeto da competência dos Municipios descrita no artigo 30 , I, da Constituição Federal.

Assim, o arcabouço jurídico que garante ao Municipio o poder de atuação em Saúde do Trabalhador é composto pela Constituição Federal, Lei Orgânica da Saúde, Constituição Estadual, eventuais leis que disciplinem as ações de Saúde do Trabalhador, como no caso de São Paulo, Lei Orgânica do Municipio e a Lei Municipal, a qual poderá adotar o Código Sanitário do Estado, se não houver oportunidade de criar um Código de Posturas Municipais próprio. No caso do Estado de São Paulo, o Código Sanitário do Estado (SÃO PAULO, 1998-a) contempla o tema Saúde e Trabalho.

Cabe ao poder público o papel de mediar negociações com o objetivo de proteger a saúde e segurança dos trabalhadores, buscando a colaboração da sociedade e do empresariado e sindicatos em particular. 
Significa que a prática da vigilância em saúde do trabalhador deve buscar negociações entre as centrais sindicais, sindicatos de forma geral, associações de portadores de doenças profissionais, entidades patronais e sindicatos para que as questōes que envolvem os agravos à saúde dos trabalhadores caminhem para sua eliminação.

A imposição de penalidades, principalmente aquelas mais complexas, como as interdições, a não ser em casos extremos, não devem ser 0 objetivo da atuação. Deve-se buscar, sempre, mesmo que a prazos mais longos, desde que razoáveis, a solução dos casos através de instrumentalização técnica das negociações entre as principais partes interessadas, ou seja, o capital e o trabalho.

A fiscalização dos ambientes de trabalho deve evitar os equívocos que vêm sendo cometidos pela estratégia adotada pelo Ministério do Trabalho, órgão tradicionalmente responsável pela fiscalização dos ambientes de trabalho no Brasil. Deve-se ter em mente a execução de práticas transformadoras dos ambientes de trabalho nocivos e năo apenas a sua detecção e punição.

O financiamento das ações de saúde do trabalhador deve ficar a cargo exclusivo do Município. Desde 1996, através de Portaria Interministerial da Previdência Social e Saúde(BRASIL, 1996), estão previstos incentivos financeiros para que os municipios executem ações de saúde do trabalhador, o que também foi reforçado na Norma Operacional de Saúde do Trabalhador (MINISTÉRIO DA SAÚDE, 1998-a), porém, até o momento a questão não está contemplada.

A Norma Operacional de Assistência à Saúde - NOAS recentemente editada pelo Ministério da Saúde e que se encontra em implantação, também não prevê incentivos financeiros para a execução de ações de saúde do trabalhador. 
Por fim, a participação dos principais interessados na saúde do trabalhador deve ser buscada, incentivada e aprimorada, não só por ser princípio do SUS, nem apenas por garantir a apropriação do programa pelos usuários e com isto a sua incorporação à instituição. A participação dos trabalhadores, dos usuários do serviço, desde a elaboração do Programa, passando pelo planejamento, execução, indo até à avaliação e reestruturação, se for o caso, deve ser buscada para que se consiga utilizar toda a criatividade e conhecimento do trabalhador na fixação das bases em que se assentará o serviço.

Não pode ser negligenciada a necessidade de formação dos conselheiros para qualificar sua participação. Esta formação deve ser preparada pelo próprio serviço, ouvindo-se os próprios interessados, e deve ter como objetivo prepará-los para uma intervenção construtiva, que se baseie nas suas necessidades, prioridades, interesses, mas que também leve em conta os métodos e as regras estabelecidas para o funcionamento do serviço, as quais ele deve conhecer.

Deve ser criada uma Comissão Interinstitucional em Saúde do Trabalhador, representativa dos vários setores envolvidos na área, vinculada ao Conselho Municipal de Saúde, com caráter consultivo e fiscalizador, que debata os assuntos atinentes à área, como vários municípios já criaram com resultados satisfatórios. 


\section{REFERÊNCIAS}

1. Almeida Filho N. Transdisciplinaridade e saúde coletiva. Ciência \& Saúde Coletiva. 1997, 2 (1/2): 5-20

2. Atkinson S. Rolim Medeiros RL, Lima Oliveira PH, Dias de Almeida R. Going down top the local: incorporating social organisation and political culture into assessments of decentralised health care. Soc. Sci. Méd. 2000, 51: 619-36.

3. Barros de Oliveira MH, Brandão de Oliveira LS, Neto Ribeiro FS, Fadel de Vasconcelos LC. Análise comparativa dos dispositivos de saúde do trabalhador nas constituições estaduais brasileiras. Cad. Saúde Pub. 1997, 13 (3): 425-33.

4. Bossert T. Analyzing the decentralization on health systems in developing countries: decision space, innovation and performance. Soc. Sci. Med. 1998,. 47 (10): 1513-27.

5. Bracht N, Finnegan JR, Rissel C. Community ownership and program continuation following a health demonstration project. Health Educ. Res. 1994, 9 (2):243-55.

6. Brasil, República Federativa do, Constituição Federal, 1988.

7. Brasil, República Federativa do. Lei $n^{\circ} \mathbf{8 . 0 8 0}$, de 19 de setembro de 1990 - Dispõe sobre as condições para a promoção, proteção e recuperação da saúde, a organização e o funcionamento dos serviços correspondentes, e dá outras providências. 
8. Brasil, República Federativa do. Lei $\mathbf{n}^{\circ} \mathbf{8 . 1 4 2}$, de 28 de dezembro de 1990 - Dispõe sobre a participação da comunidade na gestão do Sistema Único de Saúde - SUS e sobre as transferências intergovernamentais de recursos financeiros na área de saúde e dá outras providências.

9. Brasil, República Federativa do. Lei no 8.212, de 24 de julho de 1991 Dispõe sobre a organização da Seguridade Social, institui Plano de Custeio, e dá outras providéncias.

10. Brasil, República Federativa do. Portaria Interministerial MPAS/MS $\mathbf{n}^{\circ}$ 14, de 13 de fevereiro de 1996.

11. Campilongo CF. $O$ trabalhador e o direito à saúde: a eficácia das normas juridicas de proteção à saúde do trabalhador. Washington (DC); 1992. (OPAS - Série Informes Técnicos, 19).

12. Carmo JC. SISCAT- Sistema de informação para acidentes e doenças do trabalho. Análise das comunicaçōes de acidentes do trabalho registradas na Zona Norte do Município de São Paulo de 1991 a 1993. São Paulo; 1996. [Dissertação de Mestrado apresentada ao Departamento de Saúde Ambiental da Faculdade de Saúde Pública].

13. Carneiro SAM. A saúde do trabalhador e a vigilância dos ambientes de trabalho [Apresentado na Conferência Intermunicipal de Saúde do Trabalhador; 1993; São Paulo, Brasil]

14. Carvalho Al, Sório RE. Capacitação de dirigentes e equipes municipais de saúde: uma proposta em construção. R. Adm. Mun. 1997, 44 (220): 73-8 
15. Carvalho GI; Santos L. Sistema Único de Saúde. Comentários à Lei Orgânica da Saúde, São Paulo, Ed. Hucitec, 1992.

16. [CEREST/SP] Centro Estadual de Referência em Saúde do Trabalhador de São Paulo. Documento preliminar do CEREST/SP para discussão sobre a política de saúde do trabalhador na Secretaria de Estado da Saúde de São Paulo, agosto de 1996, São Paulo, Brasil.

17. Cohn A . Por onde anda a reforma sanitária? Teoria e Debate 2001, (48): 10-14.

18. Conselho Nacional de Saúde. Descentralização das ações e serviços de saúde: a ousadia de cumprir e fazer cumprir a Lei. Informe Epidemiológico do SUS 1993. Número Especial: 1- 49.

19. Costa DF, Carmo JC, Settimi MM, Paula Santos U, Martins HB. Programa de saúde dos trabalhadores: histórico. In: Costa DF, Carmo JC, Settimi MM, Paula Santos U, organizadores. Programa de saúde dos trabalhadores - a experiência da Zona Norte: uma alternativa em saúde pública. São Paulo (SP); 1989. p. 19-31.

20. Dallari DA. Características generales de la Constitución de 1988. In: Dallari DA, Dallari SG, Barber-Madden R. El derecho de la salud em la nueva Constitución brasileña. Washington (DC); 1992. (OPAS - Série Informes Técnicos, 10).

21. Dallari SG. O papel do município no desenvolvimento de políticas de saúde. Rev. Saúde Pub. 1991, 25 (5): 401-5.

22. Dallari SG. Os estados brasileiros e o direito à saúde. São Paulo, Ed. Hucitec, 1995. 
23. Dias EC. Organização da atenção à saúde no trabalho. In: Ferreira Jr M. Saúde no trabalho. 2.000. Ed. Roca, São Paulo. p. 3-28.

24. Dodge REF. A eqüidade, a universalidade e a cidadania em saúde, vistas sob o prisma da Justiça. Bioética 1997, 5 (77-85).

25. Elias PE. Descentralização e saúde no Brasil: algumas reflexões preliminares. Saúde e Sociedade 1996, 5(2): 17-34.

26. Fadel de Vasconcellos LC, Ribeiro FSN. Investigação epidemiológica e intervenção sanitária em saúde do trabalhador: o planejamento segundo bases operacionais. Cad. Saúde Públ. 1997, 13 (2): 269-75.

27. Forest PG. La participation des citoyens à l'administration des services de santé. In: Lenieux V, Bergeron P, Bégin C, Bélanger $G$ (org). Le système de santè au Quebec: organizations, acteurs et enjeux (s/d) Sante Foy, Les Presses de l'Université de Laval. p. 143-61 apud Hortale VA, Pedroza M, Garcia Rosa ML. Operacionalizando as categorias acesso e descentralização na análise de sistemas de saúde. Cad. Saúde Pública 2000; 16(1): 231-9

28. Fundação Osvaldo Cruz. Curso de Especialização em Saúde do Trabalhador e Ecologia Humana. Disponivel em $<$ URL:http://www.fiocruz.br>[7 de setembro de 2001].

29. Haguette,TMF. Metodologias qualitativas na sociologia. Petrópolis, Editora Vozes, 1995. pp. 86-91. 
30. Healy J, Mckee M. Health sector reform in Central and Eastern Europe: the professional dimension. Health Policy and Planning 1997, 12 (4): 286-95.

31. Heimann LS, Cortizo CT, Castro IEN, Kayano J, Rocha JL, Nascimento PR, Boaretto RC, Pessoto UC, Junqueira V. Descentralização do Sistema Único de Saúde: trilhando a autonomia municipal. São Paulo, Sociedade Brasileira de Vigilância de Medicamentos, 2000. p. 2534.

32. Hortale VA. O conceito de descentralização aplicado aos serviços de saúde: dimensões, padrões e regularidades. Rev. Adm. Pública 1997; $31(3): 23-35$.

33. Hortale VA, Pedroza M, Garcia Rosa ML. Operacionalizando as categorias acesso e descentralização na análise de sistemas de saúde. Cad. Saúde Pública 2000; 16 (1): 231-9.

34. Huet Machado JM. Processo de vigilåncia em saúde do trabalhador. Cad. Saúde Publ. 1997, 13 (supl. 2) [periódio on-line] Disponível em <URL: http://uww.scielo.org> [18 de outubro de 2000].

35. Junqueira LAP. Mudança uma causa compartilhada: do ERSA ao SUS. São Paulo, 1996. [Tese de Doutorado apresentada à Faculdade de Saúde Pública da Universidade de Săo Paulo].

36. Junqueira LAP. Descentralização e mudança nas organizações públicas de saúde. Cad. Fundap 1997 (21): 137- 55

37. Junqueira LAP. Novas formas de gestão na saúde: descentralização e intersetorialidade. Saúde e Sociedade 1997, 6 (2): 31-46. 
38. Junqueira LAP. A descentralização e a reforma do aparato estatal em saúde. In: Canesqui AM., organizadora. Ciências Sociais e Saúde. São Paulo (SP): Ed. Hucitec-ABRASCO; 1997. p. 173-204.

39. Junqueira LAP. Descentralização e intersetorialidade: a construção de um modelo de gestão municipal. Rev. Adm. Pública 1998, 32(2): 11-22.

40. Kliksberg B. Como reformar o Estado para enfrentar os desafios sociais do terceiro milênio. Rev. Adm. Pública 2001, 35 (2): 119-51.

41. Lacaz FAC. Saúde do trabalhador: cenários e perspectivas numa conjuntura privatista [Apresentado ao Seminário da Diretoria do Sintratel; 2000; São Paulo, Brasil].

42. Lordello de Mello D. Governo e administração municipal: a experiência brasileira. Rev. Adm. Pública 2001. 35 (2): 79-96.

43. Matus C. Sobre la teoria de las macroorganizaciones. Santafé de Bogotá: Fondo Editorial Altadir. 1994 apud: Uribe Rivera FJ. A gestão situacional (em saúde) e a organização comunicante. Cad. Saúde Pública 1996, 12 (3) [periódico on-line] Disponivel em <URL:http://www.scielo.org> [18 de outubro de 2000].

44. Mendes EV. A descentralização do sistema de serviços de saúde no Brasil: novos rumos e um outro olhar sobre o nível local. In: Mendes EV, organizador. A organização da saúde no nível local. São Paulo (SP); Editora Hucitec; 1998. p. 17-56.

45. Menendez EL. Participación social em salud como realidad técnica y como imaginario social privado. Cuad. Médico Sociales 1998, 73: 5.22. 
46. Minayo-Gomez C, Thedim-Costa SMF. A construção do campo da saúde do trabalhador: percurso e dilemas. Cad. Saúde Pub. 1997, 13 (supl. 2) [periódico on-line] Disponivel em <URL:http://www.scielo.org> [18 de outubro de 2000].

47. Ministério da Saúde - Relatório da $8^{a}$. Conferência Nacional de Saúde, 1986

48. Ministério da Saúde - Norma Operacional Básica 01/93. Informe Epidemiológico do SUS 1993 (Número especial): 52- 73.

49. Ministério Da Saúde - Norma Operacional Básica do Sistema único de Saúde 01/96. "Gestão plena com responsabilidade pela saúde do cidadão", Ministério da Saúde, 1996.

50. Ministério da Saúde - Gabinete do Ministro - Portaria 3.120, de $1^{\circ}$ de julho de 1998.

51. Ministério da Saúde - Gabinete do Ministro - Portaria 3.908, de 30 de outubro de 1998.

52. Ministério da Saúde - Descentralização. [on-line] Disponivel em URL:http://www.saude.gov.br/descent/habilita.htm [30 de junho de 2000].

53. Ministério da Saúde. 11` Conferência Nacional de Saúde - Relatório Final, 2.001. 
54. Ministério da Saúde. Norma Operacional da Assistência à Saúde. Disponivel em URL:http://www.saude.gov.br/descentralizacao $[7$ de setembro de 2.001]

55. Ministério da Saúde. Portaria $n^{\circ}$ 1.969, de 25 de outubro de 2.001. Dispõe sobre o preenchimento de Autorização de Internação Hospitalar - AlH, em casos de quadro compativel com causas externas e com doenças e acidentes relacionados ao trabalho

56. Ministério da Saúde - SUS - Descentralização [on-line] Disponivel em URL:http://www.saude.gov.br/biblioteca/publicações.htm $\quad\left[\begin{array}{ll}20 & \text { de }\end{array}\right.$ janeiro de 2002].

57. Ministério do Trabalho e Emprego - Gabinete do Ministro - Portaria 3.214, de 8 de junho de 1978

58. Motta PR. Participação e descentralização administrativa: lições de experiências brasileiras. Rev. Adm. Pública 1994; 28 (3): 174-94.

59. Otani K. A qualidade de vida do trabalhador do SUS [Apresentado na Mesa Temática da III Conferência Estadual de Saúde de São Paulo; 2001 set 17; São Paulo, Brasil]

60. Paim JS. Políticas de descentralização e atenção primária à saúde. In: Rouquairol MZ, Almeida Filho N. Epidemiologia e saúde. Medsi, Rio de Janeiro, 1999. pp. 489.

61. Renaud L, Chevalier S, O'Loughlin J. Línstitutionnlisation des programmes communautaires: revue des modèles théoriques et proposition d'un modèle. Revue Canadienne de Santé Publique 1997, 88(2): $109-13$ 
62. Repullo Junior, R. Programa de Saúde do Trabalhador para o Municipio de Diadema - Estado de São Paulo; 1994 [Trabalho apresentado na Disciplina Saúde do Trabalhador - Política, Ensino e Pesquisa do Curso de Pós-Graduação em Saúde Pública - Faculdade de Saúde Pública da USP]

63. Repullo Junior. R, Leal, RM. Programa de Saúde do Trabalhador para o Município de Poá; 1997 [Trabalho apresentado à Secretaria Municipal de Saúde de Poá - SPI.

64. Rey Dei Castilio J. Análisis del origen, situación y perspectivas de futuro del proceso de descentralización sanitario espanol. Rev Esp Salud Pública 1998; 72(1): 13-24.

65. Ribeiro HP; Wünsch Filho V.; Lacaz A FC; Narvai PC; Repullo Junior R. Projeto de políticas e práticas na área de saúde do trabalhador para o Estado de Săo Paulo. Relatório 1: diagnóstico de situação e propostas. São Paulo; 1998 (Faculdade de Saúde Pública da USP)

66. Rinaldi LB, Degrandi ML, Sperotto SDM, Callai RLR. Qual a autonomia municipal na gestão da saúde? Da Casa Editora, Porto Alegre, 1997. p. 28.

67. Rodriguez Neto, E. Papel ético da descentralização na implantação do Sistema único de Saúde. Bioética 1997; 5 (1): 67-70.

68. Rogers EM. Diffusion of Innovations. New York: The Free Press, 1983. apud Renaud L, Chevalier S, O'Loughlin J. Línstitutionnlisation des programmes communautaires: revue des modèles théoriques et 
proposition d'un modèle. Revue Canadienne de Santé Publique 1997, 88(2): 109-13

69. Salerno S, Capacci F, Carnevale F, Tartaglia R. Attivitá dei medico del lavoro in un servizio pubblico di prevenzione. Un caso italiano. Med Lav 1996, 88 (2): 108-20.

70. Săo Paulo. Estado de. Lei n 9.505, de 11 de março de 1999. Disciplina as ações e serviços de saúde do trabalhador no Sistema Único de Saúde.

71. Săo Paulo. Estado de. Lei $n^{\circ}$ 10.083, de 23 de setembro de 1998. Dispõe sobre o Código Sanitário do Estado.

72. São Paulo, Secretaria de Estado da Saúde de. Resolução SS-196, de 29 de dezembro de 1998.

73. Sato L. As implicações do conhecimento prático para a vigilância em saúde do trabalhador. Cad. Saúde Públ. [periódico on-line] 1996, 12(4). Disponivel em<URL: http://www.scielo.org> [18 de outubro de 2000].

74. Sena JF. Saúde, vigilância e assistência à saúde do trabalhador. In: Saúde do trabalhador: Papel do Estado e responsabilidade social; 2.000 jun 1; Brasilia - DF, Brasil. Câmara dos Deputados; 2.000. p. 12-7.

75. Silveira de Quadros, CS, Gonçalves Rua, FM, Morrone, LC, Gomes JR. Avaliação de programa de qualificação de recursos humanos em saúde do trabalhador. Rev. Bras. Saúde Ocup. 1992, 20 (75): 10-6.

76. Solórzano FX. El sisterna de salud del Canada y su financiamento. Rev Panam Salud Publica 1997; 1(3): 180-5. 
77. Sousa Campos GW. Análisis crítico de las contribuciones del cuerpo teórico de la salud pública a las prácticas sanitarias. Cuad. Méd. Sociales 1999, 74: 79-90.

78. Spedo SM. Saúde do Trabalhador no Brasil: Análise do modelo de atenção proposto para o Sistema Único de Saúde. Campinas, 1998. [Dissertação de Mestrado apresentada à Faculdade de Ciências Médicas da Universidade Estadual de Campinas

79. Stake RE. Case studies. In: Denzin NK; Lincoin YS. Handbook of qualitative research. Thousand Oaks, CA - SAGE, 1994. pp. 237-47.

80. Stout N, Bell C. Effectiveness of source documents for identifying fatal occupational injuries: a synthesis of studies. Am. J. Pub. Health 1991, 81(6): 725-8

81. Uribe Rivera FJ. A gestão situacional (em saúde) e a organização comunicante. Cad. Saúde Pública ['periódico on-line] 1996, 12 (3). Disponivel em <URL:http://www.scielo.org> [18 de outubro de 2000].

82. Vasconcelos E. Desinstitucionalização e interdisciplinaridade em saúde mental. Rio de Janeiro; 1996. [Escola de Serviço Social da UERJ]

83. [WHO] World Heaith Organization. The world health report 2000. Health systems. irnproving performances. Geneva; 2.000

84. Wunsch JS. Descentralization. Public Admin. Dev. 2001, 21(4): 277-88 


\section{ANEXO 1}

\section{TERMO DE CONSENTIMENTO}

Eu,

Declaro que concordo em participar, voluntariamente, de pesquisa científica sobre "Municipalização das Atividades de Saúde do Trabalhador no Sistema Único de Saúde", que vem sendo realizada sob responsabilidade de Rodolpho Repullo Junior, aluno do Curso de Pós-Graduação - Nível Doutorado - da Faculdade de Saúde Pública da Universidade de São Paulo. Estou ciente de que os resultados são confidenciais e que serão utilizados unicamente para fins de pesquisa. Autorizo a publicação dos resultados das análises em conjunto para efeito público. Os resultados individuais somente serão comunicados para minha pessoa. Posso, a qualquer momento, abandonar esta pesquisa, sem qualquer tipo de prejuízo pessoal.

São Paulo, de de 2.001 .

\section{Assinatura do pesquisado}

Obs. Em caso de dúvida, entrar em contato com o pesquisador através do telefone 4043-0391. 


\section{ANEXO 2 \\ MINISTÉRIO DA SAÚDE - GABINETE DO MINISTRO PORTARIA NO 3.120, DE $1^{\circ}$ DE JULHO DE 1998*}

O Ministro de Estado da Saúde, no uso da atribuição que lhe confere o art. 87, inciso II, da Constituição Federal, tendo em vista o disposto em seu art. 200 , inciso II, combinado com os preceitos da Lei no 8.080, de 19 de setembro de 1990,

considerando que as determinaçōes contidas na NOB-SUS 01/96 incluem a Saúde do Trabalhador como campo de atuação da atenção à saúde;

Considerando as determinações contidas na Resolução no 220, de 6 de março de 1997, do Conselho Nacional de Saúde, e na Instrução Normativa no 01/97, de 15 de maio de 1997, do Ministério da Saúde, resolve:

Art. $1^{\circ}$ Aprovar a Instrução Normativa de Vigilância em Saúde do Trabalhador no SUS, na forma do Anexo a esta Portaria, com a finalidade de definir procedimentos básicos para $\circ$ desenvolvimento das ações correspondentes.

Art. $2^{\circ}$ Esta Portaria entrará em vigor na data de sua publicação.

$$
\text { JOSÉ SERRA }
$$

DOU No 124 Quinta-feira, 14 julho, Seção 1.

\section{ANEXO - INSTRUÇÃO NORMATIVA DE VIGILÂNCIA EM SAÚDE DO TRABALHADOR NO SUS}

1 - Apresentação 
O avanço gradual, quantitativo e qualitativo da institucionalizaçăo das práticas de Saúde do Trabalhador, no setor saúde em todo o Brasil, reflete a consolidação da área como objeto indiscutivel da saúde pública. E, por assim dizer, objeto, também, das políticas públicas direcionadas, em todos os níveis do Sistema Único de Saúde (SUS), para a prevenção dos agravos à saúde da população trabalhadora.

O conjunto de elementos deflagradores do avanço institucional, em relação à questăo da Saúde do Trabalhador no SUS, compõe-se do aspecto legislativo, calcado na Lei $n^{\circ} 8.080$, de 19 de setembro de 1990, e em diversas Constituições Estaduais e Municipais, na luta pela saúde desenvolvida pelos trabalhadores e suas organizações sindicais, passando pelo crescente comprometimento dos técnicos, ao nível dos serviços e universidades.

A presente Instrução Normativa pretende, de uma forma sucinta, fornecer subsídios básicos para o desenvolvimento de ações de Vigilância em Saúde do Trabalhador, no âmbito do Sistema Único de Saúde. Parte do pressuposto que o sistema de saúde, embora deva ser preservado nas suas peculiaridades regionais que impliquem um respeito às diversas culturas e caracteristicas populacionais, por ser único, também deve manter linhas mestras de atuação, especialmente pela necessidade de se compatibilizarem instrumentos, bancos de informaçōes e intercâmbio de experiências.

As recomendações aqui apresentadas são fruto de alguns anos de discussão acumulada e extraida de diversas experiências de vigilância em saúde do trabalhador, em vários estados e municípios de todo o País.

Trata-se de uma primeira aproximação normativa não só com os Programas Estaduais e Municipais de Saúde do Trabalhador, já instalados e em fase de instalação, mas, também com as estruturas de atenção à saúde das Secretarias 
Estaduais e Municipais, especialmente nas áreas de Vigilância Epidemiológica, Vigilância Sanitária e Fiscalização Sanitária.

A possibilidade de traduzir a capilaridade institucional do setor saúde em instáncias efetoras de mudança dos perfis de morbidade e mortalidade, resultantes da relação trabalho-ambiente-consumo e saúde, pressupõe um comprometimento das estruturas de atenção à saúde, em especial as de vigilância e fiscalização em saúde.

O objetivo da Instrução Normativa é, em suma, o de poder instrumentalizar minimamente os setores responsáveis pela vigilância e defesa da saúde, nas Secretarias de Estados e Municípios, de forma a incorporarem em suas práticas mecanismos de análise e intervenção sobre os processos e os ambientes de trabalho.

A abordagem de vigilância em saúde do trabalhador, considerada na Instruçăo Normativa, implica a superaçăo dos limites conceituais e institucionais, tradicionalmente estruturados nos serviços de saúde, das ações dissociadas de vigilância epidemiológica e sanitária.

Além disso, nas ações de vigilância e fiscalização sanitária, propriamente ditas, implica-se transpor o objeto usual - o produto/consumidor - de forma a considerar, igualmente, como objeto, o processo/trabalhador/ambiente.

Dessa forma, a vigilância em saúde do trabalhador calca-se no modelo epidemiológico de pesquisa dos agravos, nos diversos níveis da relaçăo entre o trabalho e a saúde, agregando ao universo da avaliação e análise a capacidade imediata da intervenção sobre os fatores determinantes dos danos à saúde.

Devido à sua concepção mais abrangente de saúde, relacionada ao processo de produção, capaz de lidar com a diversidade, a complexidade e o 
surgimento de novas formas de adoecer, a vigilância em saúde do trabalhador ultrapassa 0 aspecto normativo tratado pela fiscalização tradicional.

Em razão dessas implicações, a vigilância em saúde do trabalhador pressupõe uma rede de articulaçőes que passa, fundamentalmente, pelos trabalhadores e suas organizações, pela área de pesquisa e formação de recursos humanos e pelas áreas de assistência e reabilitação.

Finalmente, levando-se em consideração o fato de ser uma área ainda em construção dentro do SUS, pretende-se que esta Instrução Normativa possa ser aprimorado, com a maior brevidade, uma vez utilizado pela rede de serviços, assim como se constitui na primeira de uma série de publicações normativas e orientadoras, relacionadas a temas específicos em saúde do trabalhador.

\section{2 - Conceituação básica}

A Vigilância em Saúde do Trabalhador compreende uma atuação contínua e sistemática, ao longo do tempo, no sentido de detectar, conhecer, pesquisar e analisar os fatores determinantes e condicionantes dos agravos à saúde relacionados aos processos e ambientes de trabalho, em seus aspectos tecnológico, social, organizacional e epidemiológico, com a finalidade de planejar, executar e avaliar intervenções sobre esses aspectos, de forma a eliminá-los ou controlá-los.

A Vigilância em Saúde do Trabalhador compõe um conjunto de práticas sanitárias, articuladas supra-setorialmente, cuja especificidade está centrada na relação da saúde com 0 ambiente e os processos de trabalho e nesta com a assistência, calcado nos princípios da vigilância em saúde, para a melhoria das condiçōes de vida e saúde da população. 
A Vigilância em Saúde do Trabalhador não constitui uma área desvinculada e independente da vigilância em saúde como um todo mas, ao contrário, pretende acrescentar ao conjunto de ações da vigilância em saúde estratégias de produção de conhecimentos e mecanismos de intervenção sobre os processos de produção, aproximando os diversos objetos comuns das práticas sanitárias àqueles oriundos da relação entre o trabalho e a saúde.

\section{3 - Princípios}

A Vigilåncia em Saúde do Trabalhador pauta-se nos principios do Sistema Único de Saúde, em consonância com os Sistemas Nacionais de Vigilância Sanitária e de Vigilância Epidemiológica, articulada com a área assistencial.

Além disso, tendo em vista a complexidade e a abrangência do objeto da vigilância, guarda peculiaridades que transpõem os limites setoriais da saúde, implicando a ampliação de sua abordagem.

Como princípios, esquematicamente, pode-se considerar:

3.1 - Universalidade: todos os trabalhadores, independentemente de sua localizaçăo, urbana ou rural, de sua forma de inserção no mercado de trabalho, formal ou informal, de seu vínculo empregatício, público ou privado, autônomo, doméstico, aposentado ou demitido são objeto e sujeitos da Vigilância em Saúde do Trabalhador.

3.2 - Integralidade das ações: o entendimento de atenção integral à saúde do trabalhador, compreendendo a assistência e recuperação dos agravos, os aspectos preventivos implicando intervenção sobre seus fatores determinantes em nivel dos processos de trabalho e a promoção da saúde que implicam ações articuladas com os próprios trabalhadores e suas representações. A ênfase deve ser dirigida ao fato de que as ações individuais/curativas articulam-se com as 
ações coletivas, no âmbito da vigilância, considerando que os agravos à saúde do trabalhador são absolutamente preveniveis.

3.3 - Pluriinstitucionalidade: articulação, com formaçăo de redes e sistemas, entre as instâncias de vigilância em saúde do trabalhador e os centros de assisténcia e reabilitação, as universidades e centros de pesquisa e as instituições públicas com responsabilidade na área de saúde do trabalhador, consumo e ambiente.

3.4 - Controle social: incorporação dos trabalhadores e das suas organizações, principalmente as sindicais, em todas as etapas da vigilância em saúde do trabalhador, compreendendo sua participação na identificação das demandas, no planejamento, no estabelecimento de prioridades e adoção de estratégias, na execução das açōes, no seu acompanhamento e avaliação e no controle da aplicação de recursos.

3.5 - Hierarquização e descentralização: consolidação do papel do município e dos distritos sanitários como instância efetiva de desenvolvimento das ações de vigilância em saúde do trabalhador, integrando os níveis estadual e nacional do Sistema Único de Saúde, no espectro da ação, em função de sua complexidade.

3.6 - Interdisciplinaridade: a abordagem multiprofissional sobre o objeto da vigilância em saúde do trabalhador deve contemplar os saberes técnicos, com a concorrência de diferentes áreas do conhecimento e, fundamentalmente, o saber operário, necessários para o desenvolvimento da ação.

3.7 - Pesquisa-intervenção: o entendimento de que a intervenção, no ámbito da vigilância em saúde do trabalhador, é o deflagrador de um processo contínuo, ao longo do tempo, em que a pesquisa é sua parte indissolúvel, subsidiando e aprimorando a própria intervenção. 
3.8 - O caráter transformador: a intervenção sobre os fatores determinantes e condicionantes dos problemas de saúde relacionados aos processos e ambientes de trabalho com o entendimento de que a vigilância em saúde do trabalhador, sob a lógica do controle social e da transparência das ações, pode ter na intervenção um caráter proponente de mudanças dos processos de trabalho, a partir das análises tecnológica, ergonômica, organizacional e ambiental efetuadas pelo coletivo de instituições, sindicatos, trabalhadores e empresas, inclusive, superando a própria legislação.

\section{4-Objetivos}

De forma esquemática pode-se dizer que a vigilância em saúde do trabalhador tem como objetivos:

a - conhecer a realidade de saúde da população trabalhadora, independentemente da forma de inserção no mercado de trabalho e do vínculo trabalhista estabelecido, considerando:

a1 - a caracterização de sua forma de adoecer e morrer em função da sua relação com o processo de trabalho;

a2 - o levantamento histórico dos perfis de morbidade e mortalidade em função da sua relação com o processo de trabalho;

a3 - a avaliação do processo, do ambiente e das condições em que o trabalho se realiza, identificando os riscos e cargas de trabalho a que está sujeita, nos seus aspectos tecnológicos, ergonômicos e organizacionais já conhecidos;

a4 - a pesquisa e a análise de novas e ainda desconhecidas formas de adoecer e morrer em decorrência do trabalho; 
b - intervir nos fatores determinantes de agravos à saúde da população trabalhadora, visando eliminá-los ou, na sua impossibilidade, atenuá-los e controlá-los, considerando:

b1 - a fiscalização do processo, do ambiente e das condições em que o trabalho se realiza, fazendo cumprir, com rigor, as normas e legislações existentes, nacionais ou mesmo internacionais, quando relacionadas à promoção da saúde do trabalhador;

b2 - a negociação coletiva em saúde do trabalhador, além dos preceitos legais estabelecidos, quando se impuser a transformação do processo, do ambiente e das condições em que 0 trabalho se realiza, não prevista normativamente;

c - avaliar o impacto das medidas adotadas para a eliminação, atenuação e controle dos fatores determinantes de agravos à saúde, considerando:

c1 - a possibilidade de transformar os perfis de morbidade e mortalidade;

c2 - o aprimoramento contínuo da qualidade de vida no trabalho;

d - subsidiar a tomada de decisões dos órgãos competentes nas três esferas de governo, considerando:

d1 - o estabelecimento de políticas públicas, contemplando a relação entre o trabalho e a saúde no campo de abrangência da vigilância em saúde;

d2 - a interveniência, junto às instâncias do Estado e da sociedade, para o aprimoramento das normas legais existentes e para a criação de novas normas legais em defesa da saúde dos trabalhadores; 
d3 - o planejamento das ações e o estabelecimento de suas estratégias;

d4 - a participação na estruturação de serviços de atenção à saúde dos trabalhadores;

d5 - a participação na formação, capacitação e treinamento de recursos humanos com interesse na área;

e - estabelecer sistemas de informação em saúde do trabalhador, junto às estruturas existentes no setor saúde, considerando:

e1 - a criação de bases de dados comportando todas as informações oriundas do processo de vigilância e incorporando as informações tradicionais já existentes;

e2 - a divulgação sistemática das informações analisadas e consolidadas.

\section{5 - Estratégias}

A vigilância em saúde do trabalhador, como um conjunto de práticas sanitárias contínuas, calcada, entre outros princípios, na interdisciplinaridade, na pluriinstitucionalidade, no controle social, balisada na configuração do Sistema Único de Saúde, e tendo como imagem-objetivo a melhoria da qualidade de vida no trabalho, pressupõe o estabelecimento de estratégias operacionais para alcançá-la.

Embora cada Estado, Região ou Município, guardadas suas características, deva buscar a melhor forma de estabelecer suas próprias estratégias de vigilância, alguns pressupostos podem ser considerados como aplicáveis ao conjunto do SUS. Dentre os passos que podem ser estabelecidos na estratégia de 
operacionalização das ações, buscando manter uma lógica seqüencial de consolidação da vigilância, pode-se destacar:

5.1 - Onde já existam estruturas, estaduais e municipais, de saúde do trabalhador - Programas, Coordenações, Divisões, Gerências, Centros, Núcleos promover e/ou aprofundar a relação institucional com as estruturas de Vigilância Epidemiológica, Vigilância Sanitária e Fiscalização Sanitária, busicando a superação da dicotomia existente em suas práticas, em que o objeto de ação da vigilância, em geral, não contempla o processo de produção e sua relação com a saúde dos trabalhadores. Com este intuito, recomenda-se a constituição de equipes multiprofissionais para a execução de ações interdisciplinares e pluriinstitucionais.

5.2 - Recomenda-se a criação de comissão, na forma colegiada, com a participação de trabalhadores, suas organizações sindicais e instituições públicas com responsabilidades em saúde do trabalhador, vinculada organicamente ao SUS e subordinada aos Conselhos Estaduais e Municipais de Saúde, com a finalidade de assessorá-lo na definição de políticas, no estabelecimento de diretrizes e prioridades, e no acompanhamento e avaliação da execução das ações de saúde do trabalhador.

5.3 - Dada a abrangência e as dificuldades operacionais de se implementarem, simultaneamente, ações de vigilância em todos os ambientes de trabalho, em um dado municipio ou região, faz-se necessário o planejarnento dessas ações com o estabelecimento de prioridades, visando a intervenções de impacto, com efeitos educativos e disciplinadores sobre o setor. Para tanto, recomenda-se a adoção de alguns critérios como:

Base Sindical: Uma vez que um determinado sindicato de trabalhadiores, com alguma tradição de luta pela saúde identifique e encaminhe situações-problema, junto à estrutura de vigilância, desencadeia-se uma ação integrada que visa atuar 
não apenas na empresa denunciada, mas nas principais empresas abrangidas por aquela categoria de trabalhadores. $O$ investimento da ação nesta base deve considerar a capacidade de reprodutibilidade, a partir do sindicato em questão e para o movimento sindical como um todo, numa dada região.

- Ramo Produtivo: Consiste na atuação em todas as empresas com o mesmo perfil produtivo, capaz de se constituir em fonte de risco para a saúde, preponderantes numa dada região, independente da capacidade de mobilização dos sindicatos envolvidos. A utilização deste critério pode se dar por avaliação epidemiológica dos casos notificados, denúncias sucessivas ou análise dos processos produtivos. $O$ investimento da ação, neste caso, visa à mudança dos processos de forma integrada, sem a punição de uma empresa em particular, mas intervindo em todas as empresas daquele setor $e$, em especial, nas que apresentam grande concentração de trabalhadores, sempre buscando a atuação conjunta com os sindicatos das categorias expostas.

- Território: Consiste na intervenção por varredura, em pequena área geográfica previamente delimitada (setor censitário, distrito de saúde, bairro, distrito industrial etc.), de todos os processos produtivos capazes de gerar dano à saúde. 0 investimento da ação, neste caso, visa abranger todos os trabalhadores, ao longo do tempo, a despeito de sua forma de inserção no mercado de trabalho e seu vínculo de emprego, a partir da elaboração de mapas dos processos produtivos, de modo a estabelecer um perfil de risco à saúde dos trabalhadores.

- Epidemiológico (evento-sentinela): Consiste na intervenção nas empresas, a partir de agravos à saúde dos trabalhadores que podem representar um problema coletivo, ainda não detectado, e mesmo um problema epidemiológico relevante, mas submerso. A intervenção dirige-se à maior ou às maiores empresas considerando os aspectos potenciais de freqüência e/ou gravidade dos eventossentinela. 
É importante salientar que os critérios acima não obedecem à ordem de hierarquia e tampouco são excludentes, podendo ser utilizados de forma combinada.

5.4 - Como estratégia de consolidação das ações de vigilância em saúde do trabalhador é fundamental que os Estados e os Municipios contemplem o tema na revisão de seus códigos de saúde.

\section{6 - Metodologia}

Considerando os objetivos da vigilância em saúde do trabalhador conhecer a realidade para transformá-la, buscando um aprimoramento da qualidade de vida no trabalho - é necessário que se adotem metodologias capazes de estabelecer um diagnóstico situacional, dentro do princípio da pesquisaintervenção, e capazes, ainda, de avaliar de modo permanente os seus resultados no sentido das mudanças pretendidas.

Nesta linha, podem-se observar alguns pressupostos de caráter metodológico, compreendendo:

\section{1 - Fase preparatória}

Uma vez identificada a demanda, com base nas estratégias relacionadas, o planejamento da ação pressupõe uma fase preparatória, em que a equipe busca conhecer, com o maior aprofundamento possivel, o(s) processo(s), o ambiente e as condições de trabalho do local onde será realizada a ação.

A preparação deve ser efetuada por meio de análise conjunta com os trabalhadores da(s) empresa(s) - objeto da vigilância e dos representantes sindicais daquela(s) categoria(s), tendo por objetivo não só aprofundar o 
conhecimento sobre o objeto da vigilância, através de seu saber operário mas, principalmente, traçar estratégias de desenvolvimento da ação.

Deve-se lançar mão, ainda nesta fase, de consulta bibliográfica especializada e das informações locais disponiveis acerca do caso em questão.

\section{2 - A intervenção (inspeção/fiscalizaçăo sanitária)}

A intervenção, realizada em conjunto com os representantes dos trabalhadores, de outras instituições, e sob a responsabilidade administrativa da equipe da Secretaria Estadual e/ou Municipal de Saúde, deverá considerar, na inspeção sanitária em saúde do trabalhador, a observância das normas e legislações que regulamentam a relação entre o trabalho e a saúde, de qualquer origem, especialmente na esfera da saúde, do trabalho, da previdência, do meio ambiente e das internacionais ratificadas pelo Brasil.

Além disso, é preciso considerar os aspectos passiveis de causar dano à saúde, mesmo que não estejam previstos nas legislaçōes, considerando-se não só a observação direta por parte da equipe de situaçōes de risco à saúde como, também, as questões subjetivas referidas pelos trabalhadores na relação de sua saúde com o trabalho realizado.

Os instrumentos administrativos de registro da ação, de exigências e outras medidas são os mesmos utilizados pelas áreas de Vigilância/Fiscalização Sanitária, tais como os Termos de Visita, Notificação, Intimação, Auto de Infração etc.

\section{3 - Análise dos processos}

Uma forma importante de considerar a capacidade potencial de adoecer no processo, no ambiente ou em decorrência das condições em que o trabalho se 
realiza é utilizar instrumentos que inventariem o processo produtivo e a sua forma de organização. Os instrumentos metodológicos, a ser estabelecidos no âmbito do SUS, devem ser entregues no ato da inspeção, para serem preenchidos pela empresa, e o Roteiro de Vigilancia, construído e aplicado pela equipe, no momento da açăo, é outra forma de conhecer os processos.

\section{4 - Inquéritos}

Como proposta metodológica de investigação, no mesmo tempo da intervençăo, podem-se organizar inquéritos, por meio da equipe interdisciplinar e de representantes sindicais e/ou dos trabalhadores, aplicando questionários ao conjunto dos trabalhadores, contemplando a sua percepção da relação entre trabalho e saúde, a morbidade referida (sinais e sintomas objetivos e subjetivos), a vivência com o acidente e o quase acidente de trabalho (incidente crítico), consigo e com os companheiros, e suas sugestões para a transformação do processo, do ambiente e das condições em que o trabalho se realiza.

\section{5 - Mapeamento de riscos}

Podem-se utilizar algumas técnicas de mapeamento de riscos dos processos produtivos, de forma gradualmente mais complexa, à medida que a intervenção se consolide $e$ as mudanças vão ocorrendo, sempre com a participação dos trabalhadores na sua elaboração.

Uma das técnicas que deve ser utilizada, especialmente em casos de acidentes graves e fatais, é a metodologia de árvore de causas para a investigação dos fatores determinantes do evento, que será objeto de publicação posterior.

Com a concorrência interdisciplinar, na equipe, de profissionais de áreas diversas e à medida que os trabalhadores se apropriem de novos conhecimentos acerca do 
tema, aprofunda-se a investigação, por intermédio da utilização de técnicas mais sofisticadas.

E importante mapear, além dos riscos tradicionalmente reconhecidos, as chamadas cargas de trabalho e as formas de desgaste do trabalhador.

\section{6 - Estudos epidemiológicos}

Os estudos epidemiológicos clássicos, tais como os seccionais, de coorte e caso controle, podem ser aplicados sempre que se identificar sua necessidade, igualmente com a concorrência, na equipe interdisciplinar de técnicos das universidades e centros de pesquisa, como assessores da equipe.

\section{7 - Acompanhamento do processo}

A intervenção implica a confecção de um relatório detalhado, incorporando o conjunto de informações coletadas, elaborado pela equipe, com a participação dos trabalhadores, servindo como paråmetro de avaliações futuras.

Em razăo do ritmo de implementação das medidas, avalia-se a necessidade do envolvimento de outras instâncias como, por exemplo, o Ministério Público, com o objetivo de garantir as mudanças requeridas.

Cabe ressaltar que o entendimento da intervenção deve ser o de um processo de acompanhamento e avaliação, ao longo do tempo, em que se deve buscar a negociação com as diversas instâncias, objetivando o aprimoramento da qualidade de vida no trabalho.

7 - Informações básicas 
As informações de interesse para as ações em saúde do trabalhador, atualmente disponiveis, limitam-se à avaliação do perfil de morbi-mortalidade da população em geral, sem lograr o conhecimento sistemático dos riscos e o dimensionamento da população trabalhadora a eles exposta, que permitam a análise e a intervenção sobre seus determinantes.

É pensando na necessidade de se avançar nesse conhecimento para fins de intervenção e prevenção efetivas dos agravos relacionados ao trabalho, que foi definido o elenco de informações aqui apresentadas, sem perder a perspectiva de ser acrescidas outras de interesse local, regional ou mesmo nacional, à medida que o sistema de informações em saúde do trabalhador se estruture e se consolide.

\section{1 - Informações acerca da mortalidade}

As informações de mortalidade serão coletadas principalmente a partir da Declaração de Obito, por intermédio do Sistema de Informações sobre Mortalidade (SIM). Cada Municipio deverá investir na melhoria da qualidade dos dados da Declaração de Óbito e, sempre que possível, cruzar com outras informações disponiveis, principalmente a Comunicação de Acidente de Trabalho (CAT), da Previdência Social.

\section{2 - Informações acerca da morbidade}

As informaçōes de morbidade podem ser obtidas de diversas fontes, tais como a Ficha Individual de Notificação de Agravos, referente às doenças incluidas no Sistema de Notificação de Agravos Notificáveis (SINAN); a Comunicação de Acidente do Trabalho (CAT), normalmente utilizada para os trabalhadores do mercado formal de trabalho, regido pela Consolidação das Leis Trabalhistas (CLT); as fichas, prontuários e outros documentos oriundos dos atendimentos 
ambulatoriais (SIASSUS) e de internações (SIH/SUS) na rede de serviços de saúde.

Os Estados e os Municipios poderão definir eventos-sentinela a ser notificados, incluindo-os no SINAN. Essa definição deverá ter por referência a análise do parque produtivo local ou a suspeita da existência de um agravo não diagnosticado como relacionado ao trabalho. A análise dos eventos- sentinela constituir-se-á em atividade complementar ao sistema de informações, particularmente neste momento em que o diagnóstico de doenças é muito reduzido. Observar, por exemplo, excessos de mortes ou morbidade por alguns tipos de cânceres ou de achados laboratoriais (leucopenias, anemias) que possam estar ocorrendo em grupos específicos de trabalhadores.

7.3 - Informações relativas às atividades e aos processos produtivos Essas informações deverão ser obtidas à medida que os Estados e os Municípios executem e implantem as ações de vigilância.

Consideram-se, neste caso, Cadastros de Estabelecimentos, Relatórios de Inspeção, Termos de Notificação e Fichas de Vigilância. Outras informaçōes, utilizando os bancos de dados da RAIS e do IBGE, também poderão ser incorporadas, devendo ser desagregadas, por Município, para que possam ser adequadas aos niveis locais.

Outras fontes de informação que deverão ser utilizadas, à medida que 0 sistema se capacite para tal, são as dos serviços médicos e de segurança e higiene industrial de empresas, do Anexo 1 da CIPA (Norma Regulamentadora no 5, Portaria no $3.214 / 78, M T b$ ), dos sindicatos, das associaçōes patronais, dos serviços/institutos de medicina legal, de associações $\varepsilon$ entidades civis (associações de moradores, grupos ecológicos, culturais), de outros órgãos da administração pública (DETRAN, secretarias de proteção ambiental, de indústria e comércio, do trabalho etc). Devem ser considerados ainda estudos 
epidemiológicos e resultados de pesquisas de interesse da área de saúde do trabalhador, como fonte de informações.

Um maior detalhamento acerca da criação de bancos de dados e adequação das informações em saúde do trabalhador aos Sistemas de Informação existentes, considerando, entre outros, a coleta, o fluxo, o processamento, a análise e a divulgação das informações, será efetuado §m publicação posterior.

Os Estados e os Municípios poderão acrescentar outras informações e metodologias que julgarem pertinentes, inclusive sugerindo sua incorporação em âmbito nacional nas publicaçőes subseqüentes.

8 - Considerações finais

A construção do Sistema Único de Saúde pressupõe um esforço permanente na afirmação de seus princípios e na ampliação das redes solidárias institucionais com a sociedade organizada.

Dentro do SUS, a área de saúde do trabalhador emerge como um desafio a mais, no sentido de se proverem os meios necessários para atender com primazia o que, a partir de 1988, com a Constituição Federal, passou a ser atribuição precipua das Secretarias de Saúde de Estados e Municípios: a Vigilância em Saúde do Trabalhador.

É preciso considerar, contudo, as dificuldades inerentes ao sistema de saúde, cujas práticas tradicionais, de há muito enraizadas, não dispõem de mecanismos ágeis de adequação às novas necessidades, determinadas pela lei e, mesmo, ansiadas pela sociedade. 
Com este intuito, a Instrução Normativa de Vigilância em Saúde do Trabalhador pretende ser um instrumento capaz de ser um móvel de sensibilização e de ampliação das redes solidárias de construção da área especifica e do próprio Sistema Único de Saúde.

Nesta perspectiva, pretende-se, ainda, com esta Instrução Normativa, iniciar uma série de publicações temáticas afins, entre as quais se destacam as questões dos Agrotóxicos, dos Sistemas de Informações, da Investigação de Acidentes de Trabalho, das Intoxicaçōes por Metais Pesados, dos Agravos de Caráter Ergonômico, das Pneumopatias de Origem Ocupacional. 


\section{ANEXO 3}

\section{NORMA OPERACIONAL DE SAÚDE DO TRABALHADOR - NOST-SUS}

Art. $1^{\circ} \mathrm{A}$ presente Norma, complementar à NOB-SUS 01/96, tem por objetivo orientar e instrumentalizar a realização das ações de saúde do trabalhador e da trabalhadora, urbano e rural, pelos Estados, o Distrito Federal e os Municípios, as quais devem nortearse pelos seguintes pressupostos básicos: I - universalidade e eqüidade, onde todos os trabalhadores, urbanos e rurais, com carteira assinada ou não, empregados, desempregados ou aposentados, trabalhadores em empresas públicas ou privadas, devem ter acesso garantido a todos os niveis de atenção à saúde; II - integralidade das ações, tanto em termos do planejamento quanto da execução, com um movimento constante em direção à mudança do modelo assistencial para a atenção integral, articulando ações individuais e curativas com ações coletivas de vigilância da saúde, uma vez que os agravos à saúde, advindos do trabalho, são essencialmente preveníveis; III - direito à informação sobre a saúde, por meio da rede de serviços do SUS, adotando como prática cotidiana o acesso e o repasse de informações aos trabalhadores, sobretudo os riscos, os resultados de pesquisas que são realizadas e que dizem respeito diretamente à prevenção e à promoção da qualidade de vida; IV - controle social, reconhecendo o direito de participação dos trabalhadores e suas entidades representativas em todas as etapas 
do processo de atenção à saúde, desde o planejamento e estabelecimento de prioridades, o controle permanente da aplicação dos recursos, a participação nas atividades de vigilância em saúde, até a avaliação das ações realizadas; V - regionalização e hierarquização das ações de saúde do trabalhador, que deverão ser executadas por todos os niveis da rede de serviços, segundo o grau de complexidade, desde as básicas até as especializadas, organizadas em um sistema de referência e contra-referência, local e regional; $\mathrm{VI}$ - utilização do critério epidemiológico e de avaliação de riscos no planejamento e na avaliação das ações, no estabelecimento de prioridades e na alocação de recursos; VII - configuração da saúde do trabalhador como um conjunto de ações de vigilância e assistência, visando à promoção, à proteção, à recuperação e à reabilitação da saúde dos trabalhadores submetidos a riscos e agravos advindos do processo de trabalho.

Art. $2^{\circ}$ Cabe aos Estados, ao Distrito Federal e aos Municipios a execução de ações na área de saúde do trabalhador, considerando as diferenças de gênero.

Art. $3^{\circ}$ Aos Municipios, por intermédio de suas Secretarias de Saúde, caberá realizar as ações discriminadas, conforme a condição de gestão em que estejam habilitados, como seguem:

I- Na Gestão Plena da Atenção Básica, assumirá as seguintes ações de saúde do trabalhador:

a) garantia do atendimento ao acidentado do trabalho e ao suspeito 
ou portador de doença profissional ou do trabalho, por meio da rede própria ou contratada, dentro de seu nivel de responsabilidade da atenção, assegurando todas as condições necessárias para o acesso aos serviços de referência, sempre que a situação exigir; b) realização de ações de vigilância nos ambientes e processos de trabalho, compreendendo a identificação das situações de risco e a tomada de medidas pertinentes para a resolução da situação e a investigação

epidemiológica;

c) notificação dos agravos à saúde e os riscos relacionados com o trabalho, alimentando regularmente o sistema de informações dos órgãos e serviços de vigilância, assim como a base de dados de interesse

nacional;

d) estabelecimento de rotina de sistematização e análise dos dados gerados no atendimento aos agravos à saúde relacionados ao trabalho, de modo a orientar as intervenções de vigilância, a organização dos serviços e das demais ações em saúde do trabalhador;

e) utilização dos dados gerados nas atividades de atenção à saúde do trabalhador, com vistas a subsidiar a programação e avaliação das ações de saúde neste campo, e alimentar os bancos de dados de interesse nacional.

II - Na Gestão Plena do Sistema Municipal, assumirá, além das já previstas pela condição de Gestão Plena da Atenção Básica, as seguintes ações de saúde do trabalhador: a) emissão de laudos e relatórios circunstanciados sobre os agravos relacionados com o trabalho ou limitações (seqüelas) deles resultantes, por meio de recursos próprios ou do apoio de outros 
b) instituição e operacionalização de um sistema de referência para o atendimento ao acidentado do trabalho e ao suspeito ou portador de doença profissional ou do trabalho, capaz de dar suporte técnico especializado para o estabelecimento da relação do agravo com o trabalho, a confirmação diagnóstica, o tratamento, a recuperação e a reabilitação da saúde, assim como para a realização dos encaminhamentos necessários que a situação exigir; c) realização sistemática de ações de vigilância nos ambientes e processos de trabalho, compreendendo o levantamento e análise de informações, a inspeção sanitária nos locais de trabalho, a identificação e avaliação das situaçōes de risco, a elaboração de relatórios, a aplicação de procedimentos administrativos e a investigação epidemiológica

d) instituição e manutenção de cadastro atualizado das empresas classificadas nas atividades econômicas desenvolvidas no Município, com indicação dos fatores de risco que possam ser gerados para o contingente populacional, direta ou indiretamente a eles expostos;

Parágrafo único. O Município deverá manter unidade especializada de referência em Saúde do Trabalhador, para facilitar a execução das ações previstas neste artigo.

Art. $4^{\circ}$ Os Estados, nas condições de gestão avançada e plena do sistema estadual, por intermédio de suas Secretarias de Saúde, respeitadas as responsabilidades e prerrogativas dos Municipios habilitados nas condições de gestão previstas no artigo anterior, 
assumirão as seguintes ações de saúde do trabalhador: 1 - controle da qualidade das ações de saúde do trabalhador desenvolvidas pelos Municípios, preconizadas nesta Norma, conforme mecanismos de avaliação definidos em conjunto com as Secretarias Municipais de Saúde; II - definição, juntamente com os Municipios, de mecanismos de referência e contra-referência, bem como outras medidas necessárias para assegurar o pleno desenvolvimento das ações de assistência e vigilância em saúde do trabalhador; III - capacitação de recursos humanos para a realização das ações de saúde do trabalhador, no seu âmbito de atuação; IV - estabelecimento de rotina de sistematização, processamento e análise dos dados sobre saúde do trabalhador, gerados nos Municípios e no seu próprio campo de atuação, e de alimentação regular das bases de dados, estaduais e municipais; $V$ - elaboração do perfil epidemiológico da saúde dos trabalhadores no Estado, a partir de fontes de informação existentes e, se necessário, por intermédio de estudos específicos, com vistas a subsidiar a programação e avaliação das ações de atenção à saúde do

trabalhador;

VI - prestação de cooperação técnica aos Municípios, para o desenvolvimento das ações de saúde do trabalhador; VII - instituição e manutenção de cadastro atualizado das empresas, classificadas nas atividades econômicas desenvolvidas no Estado, com indicação dos fatores de risco que possam ser gerados para o contingente populacional, direta ou indiretamente a eles expostos. 
$\S 1^{\circ}$ Recomenda-se a criação de unidades especializadas em Saúde do Trabalhador para facilitar as ações previstas neste artigo.

$\S 2^{\circ} \mathrm{A}$ organização de unidades especializadas de referência em Saúde do Trabalhador, o estímulo à implementação de unidades no Município, na região ou em forma de consórcio, e o registro de $100 \%$ dos casos atendidos de acidentes de trabalho e agravos decorrentes do processo de trabalho, comporão o índice de Valorização de Resultados (IVR), de acordo com os critérios a serem definidos pela Comissão Intergestores Tripartite, e a ser estabelecido em portaria do Ministério da Saúde.

Art. $5^{\circ}$ Esta Norma trata de um conjunto de atividades essenciais para a incorporação das ações de saúde do trabalhador no contexto das ações de atenção à saúde, devendo os Estados, o Distrito Federal e os Municipios que já têm serviços e açōes organizados, ou pelas características de seu parque produtivo e perfil epidemiológico, ampliar seu espectro de ação para além do que estabelece esta Norma.

Art. $6^{\circ} \mathrm{A}$ implementação do financiamento das ações de saúde do trabalhador consiste na garantia do recebimento dos recursos por meio das fontes de transferências, já constituídas legalmente em cada esfera de governo e na definição de mecanismos que garantam que os recursos provenientes destas fontes sejam aplicados no desenvolvimento das açōes de saúde do trabalhador estabelecidas nos planos de saúde. 
Art. $7^{\circ}$ Recomenda-se ao Estado e ao Município a revisão dos Códigos de Saúde, para contemplar as ações de saúde do trabalhador.

Art. $8^{\circ}$ Compete ao Estado, ao Distrito Federal e ao Municipio estabelecer normas complementares, no seu âmbito de atuação, com o objetivo de assegurar a proteção à saúde dos trabalhadores.

Art. $9^{\circ} \mathrm{A}$ presente Norma deverá ser avaliada permanentemente, a partir dos resultados de sua implementação, consolidados pelo órgão competente do Ministério da Saúde e amplamente divulgados às instâncias do SUS.

Art. $10^{\circ}$ Recomenda-se a instituição de Comissão Intersetorial de Saúde do Trabalhador, com a participação de entidades que tenham interfaces com a área de saúde do trabalhador, subordinada aos Conselhos Estadual e Municipal de Saúde, com a finalidade de assessorá-lo na definição das politicas, no estabelecimento de prioridades e no acompanhamento e avaliação das ações de saúde do trabalhador. 


\section{ANEXO 4}

\section{MANUAL PARA A IMPLANTAÇĀO DE UM PROGRAMA MUNICIPAL DE SAÚDE DO TRABALHADOR}

\section{O PROGRAMA MUNICIPAL DE SAÚDE DO TRABALHADOR}

Formular uma política municipal de saúde do trabalhador significa contemplar a ampla gama de condicionantes da saúde e da doença no trabalho, como também as políticas de emprego, salário, previdência social, habitação, transporte, educação, entre outras politicas econômicas e sociais do Estado. Atuar em saúde do trabalhador pressupõe um compromisso com o mundo do trabalho, um posicionamento ético e um agir político, jurídico e técnico que envolve empresas, sindicatos de trabalhadores e instituições diversas, como o Ministério do Trabalho, INSS, Ministério Público, setores do Meio Ambiente, Indústria, Comércio e Desenvolvimento Econômico, além das demais esferas de direção do Sistema Único de Saúde.

As ações a serem desenvolvidas por um Programa Municipal de Saúde do Trabalhador podem ser categorizadas em:

- Assistência aos trabalhadores acidentados ou acometidos por doenças profissionais ou relacionadas ao trabalho, compreendendo as ações de diagnóstico, estabelecimento do nexo com o trabalho, recuperação da saúde e reabilitação.

- Procedimentos visando ao acesso dos trabalhadores filiados ao Seguro de Acidentes do Trabalho da Previdencia Social aos beneficios previstos na legislação, bem como às demais formas de Previdência Social, em especial dos funcionários públicos. 
- Ações de vigilância dos ambientes e processos de trabalho, incluindo normatização, fiscalização e negociação das modificações necessárias.

- Capacitação e treinamento de recursos humanos.

- Informação e educaçāo dos empregadores, trabalhadores e outros atores sociais envolvidos ou interessados no tema

Nenhuma destas ações, isoladamente, constitui novidade para os serviços de saúde. A inovação consiste na sua implementação de modo articulado, a partir do referencial teórico da saúde do trabalhador e de instrumentos de abordagem das relações trabalho-saúde-doença que buscam integrar as dimensōes individual, coletiva, técnicas e politicas envolvidas.

A integralidade da atenção é obrigatória. Seja do ponto de vista técnico, seja do ponto de vista ético, é inaceitável fazer um trabalhador retornar ao ambiente e às condições de trabalho que o vitimaram sem uma atuação sobre essa situação de risco.

A integralidade da atenção amplia-se para a comunidade no entorno do local de trabalho e para os consumidores dos produtos produzidos ou comercializados, na perspectiva ambiental, envolvendo, simultaneamente, trabalhadores, moradores e consumidores em função dos riscos e impactos que podem advir do processo de trabalho, uso de recursos naturais, circulação de produtos e tratamento de rejeitos.

É importante destacar que os problemas de saúde dos trabalhadores, à semelhança de outras questões de Saúde Pública, dificilmente podem ser resolvidos por ações exclusivas do setor Saúde. As ações mais eficazes para a garantia da saúde dos trabalhadores estão mais no âmbito da 
Economia, da Ciência e Tecnologia, na esfera da organização da produção, do que, propriamente, no setor Saúde, requerendo, portanto, uma abordagem interinstitucional. 


\section{ORGANIZAÇÃO DOS SERVIÇOS DE ATENÇÃO À SAÚDE DO TRABALHADOR}

- Ministério da Saúde publicou, a Norma Operacional de Saúde do Trabalhador - NOST-SUS - (Portaria M. S. $n^{\circ} 3.908$, de 30 de outubro de 1998) complementar à NOB $01 / 96$ "com o objetivo de orientar e instrumentalizar a realização das ações de saúde do trabalhador e da trabalhadora, urbano e rural, pelos Estados, o Distrito Federal e os Municipios, com os seguintes pressupostos básicos:

1 - universalidade e eqüidade, onde todos os trabalhadores, urbanos e rurais, com carteira assinada ou não, empregados, desempregados ou aposentados, trabalhadores em empresas públicas ou privadas, devem ter acesso garantido a todos os niveis de atenção à saúde;

11 - integralidade das ações, tanto em termos do planejamento quanto da execução, com um movimento constante em direção à mudança do modelo assistencial para a atenção integral, articulando ações individuais e curativas com ações coletivas de vigilância da saúde, uma vez que os agravos à saúde, advindos do trabalho, são essencialmente preveniveis;

III - direito à informação sobre a saúde, por meio da rede de serviços do SUS, adotando como prática cotidiana o acesso e o repasse de informações aos trabalhadores, sobretudo os riscos, os resultados de pesquisas que são realizadas e que dizem respeito diretamente à prevenção e à promoção da qualidade de vida;

IV - controle social, reconhecendo o direito de participação dos trabalhadores e suas entidades representativas em todas as etapas do processo de atenção à saúde, desde o planejamento e estabelecimento de prioridades, o controle permanente da aplicação dos recursos, a participação nas atividades de vigilância em saúde, até a avaliação das ações realizadas; 
$V$ - regionalização e hierarquização das ações de saúde do trabalhador, que deverão ser executadas por todos os niveis da rede de serviços, segundo o grau de complexidade, desde as básicas até as especializadas, organizadas em um sistema de referência e contra-referência, local e regional;

VI - utilização do critério epidemiológico e de avaliação de riscos no planejamento e na avaliação das ações, no estabelecimento de prioridades e na alocação de recursos;

VII - configuração da saúde do trabalhador como um conjunto de ações de vigilância e assistência, visando à promoção, à proteção, à recuperação e à reabilitação da saúde dos trabalhadores submetidos a riscos e agravos advindos do processo de trabalho.

Aos Municipios caberá realizar as ações discriminadas, conforme a condição de gestão em que estejam habilitados, como seguem:

Na Gestão Plena da Atenção Básica, o Municipio assumirá as seguintes ações de saúde do trabalhador:

a) garantia do atendimento ao acidentado do trabalho e ao suspeito ou portador de doença profissional ou do trabalho, por meio da rede própria ou contratada, dentro de seu nivel de responsabilidade da atenção, assegurando todas as condições necessárias para o acesso aos serviços de referência, sempre que a situação exigir;

b) realização de ações de vigilância nos ambientes e processos de trabalho, compreendendo a identificação das situações de risco e a tomada de medidas pertinentes para a resolução da situação e a investigação epidemiológica; 
c) notificação dos agravos à saúde e os riscos relacionados com o trabalho, alimentando regularmente o sistema de informações dos órgãos e serviços de vigilância, assim como a base de dados de interesse nacional;

d) estabelecimento de rotina de sistematização e análise dos dados gerados no atendimento aos agravos à saúde relacionados ao trabalho, de modo a orientar as intervenções de vigilância, a organização dos serviços e das demais ações em saúde do trabalhador;

e) utilização dos dados gerados nas atividades de atenção à saúde do trabalhador, com vistas a subsidiar a programação e avaliação das ações de saúde neste campo, e alimentar os bancos de dados de interesse nacional.

Na Gestão Plena do Sistema Municipal, assumirá, além das já previstas pela condição de Gestão Plena da Atenção Básica, as seguintes ações de saúde do trabalhador:

a) emissão de laudos e relatórios circunstanciados sobre os agravos relacionados com o trabalho ou limitações (seqüelas) deles resultantes, por meio de recursos próprios ou do apoio de outros serviços de referência;

b) instituição e operacionalização de um sistema de referência para o atendimento ao acidentado do trabalho e ao suspeito ou portador de doença profissional ou do trabalho, capaz de dar suporte técnico especializado para o estabelecimento da relação do agravo com o trabalho, a confirmação diagnóstica, o tratamento, a recuperação e a reabilitação da saúde, assim como para a realização dos encaminhamentos necessários que a situação exigir;

c) realização sistemática de ações de vigilância nos ambientes e processos de trabalho, compreendendo o levantamento e análise de informações, a inspeção sanitária nos locais de trabalho, a identificação e 
avaliação das situações de risco, a elaboração de relatórios, a aplicação de procedimentos administrativos e a investigação epidemiológica ;

d) instituição e manutenção de cadastro atualizado das empresas classificadas nas atividades econômicas desenvolvidas no Município, com indicação dos fatores de risco que possam ser gerados para o contingente populacional, direta ou indiretamente a eles expostos;"

A organização das ações e serviços voltados para a atenção à saúde do trabalhador deve ter como estratégia a sua incorporação à rede básica de serviços de Saúde Pública, isto é, Unidades Básicas de Saúde, ou Unidades de Saúde da Família, ou Centros de Saúde, como parte da atribuição do médico clínico geral, médico generalista ou médico de família. Os prontosocorros ou pronto-atendimentos também deverão realizar $O$ atendimento das urgências e emergências em saúde do trabalhador.

Devem ser promovidos treinamentos com as equipes locais de saúde e, em particular com os médicos, visando sua sensibilização para esse tipo de atendimento, Poderão ser elaborados protocolos de atendimento para as principais patologias, sugerindo-se:
- Acidentes do Trabalho
- Perda Auditiva Induzida por Ruído
- Doenças osteomusculares
- Pneumoconioses
- Dermatoses
- Intoxicações agudas e crônicas
- Câncer ocupacional

A depender da região em que está localizado o Município e pro essa razão, possuir uma maior incidência de uma determinada doença ou tipo de acidente, poderá ser dada ênfase especial a esse problema. Por exemplo, 
sindicatos de trabalhadores aos locais de trabalho, a qualquer dia e horário, fornecendo todas as informações e dados solicitados;

III - dar ampla informação aos trabalhadores e CIPAs sobre os riscos aos quais estão expostos;

IV - arcar com os custos de estudos e pesquisas que visem esclarecer os riscos de ambiente de trabalho e ao meio ambiente; $e$

V - comunicar imediatamente à autoridade sanitária a detecção de quaisquer riscos para a saúde do trabalhador, sejam físicos, químicos, biológicos, operacionais ou provenientes da organização do trabalho, elaborando cronograma e implementando a correção dos mesmos.

Artigo 31 - Os órgãos executores das açōes de saúde do trabalhador deverão desempenhar suas funções, observando os seguintes princípios e diretrizes:

1 - informar aos trabalhadores, CIPAs e respectivos sindicatos sobre os riscos e danos à saúde no exercício da atividade laborativa e nos ambientes de trabalho;

II - assegurar a participação das CIPAs, das comissões de saúde e dos sindicatos de trabalhadores na formulação, planejamento, avaliação e controle de programas de saúde do trabalhador;

III - assegurar às CIPAs, às comissōes de saúde e aos sindicatos de trabalhadores a participação nos atos de fiscalização, avaliação e pesquisa referentes ao ambiente de trabalho ou à saúde, bem como garantir acessos aos resultados obtidos;

IV - assegurar ao trabalhador em condições de risco grave ou iminente no local de trabalho a interrupção de suas atividades, sem prejuizo de quaisquer direitos, até a eliminação do risco;

V - assegurar aos sindicatos o direito de requerer ao órgão competente do Serviço de Vigilância Sanitária e Epidemiológica a interdição de máquinas, de parte ou de todo o ambiente de trabalho, quando houver exposição a risco iminente para a vida ou saúde dos trabalhadores e da população, com imediata ação do poder público competente; 
VI - considerar o conhecimento do trabalhador como tecnicamente fundamental para o levantamento das áreas de risco e dos danos à saúde;

VII - estabelecer normas técnicas para a proteção da saúde no trabalho, da mulher no período de gestação, do menor e dos portadores de deficiência; e

VIII - considerar preceitos e recomendaçōes dos organismos internacionais do trabalho, na elaboração de normas técnicas especificas.

Artigo 32 - É dever da autoridade sanitária competente indicar e obrigação do empregador adotar todas as medidas necessárias para a plena correção de irregularidades nos ambientes de trabalho, observados os seguintes niveis de prioridades:

I- eliminação das fontes de riscos;

II - medidas de controle diretamente na fonte;

III - medidas de controle no ambiente de trabalho; e

IV - utilização de equipamentos de proteção individual, que somente deverá ser permitida nas situações de emergência ou nos casos especificos em que for a única possibilidade de proteção, e dentro do prazo estabelecido no cronograma de implantação das medidas de proteção coletiva.

\section{CAPITULO II}

\section{Estruturação das Atividades e da Organização do Trabalho}

\section{SECĀO I}

\section{Dos Riscos no Processo de Produção}

Artigo 33 - O transporte, a movimentação, o manuseio e o armazenamento de materiais, o transporte de pessoas, os veículos e os equipamentos usados nestas operaçōes, deverão obedecer a critérios estabelecidos em normas técnicas, que preservem a saúde do trabalhador. 
Artigo 34 - A fabricação, importação, venda, locação, instalação, operação e manutenção de máquinas e equipamentos deverão obedecer a critérios estabelecidos em normas técnicas, que preservem a saúde do trabalhador.

Artigo 35 - As empresas deverão manter sob controle os fatores ambientais de risco à saúde do trabalhador, como ruído, iluminação, calor, frio, umidade, radiações, agentes químicos, pressōes hiperbáricas e outros de interesse da saúde, dentro dos critérios estabelecidos em normas técnicas.

Artigo 36 - A organização do trabalho deverá adequar-se às condições psicofisiológicas e ergonômicas dos trabalhadores, tendo em vista as possiveis repercussōes negativas sobre a saúde, quer diretamente através dos fatores que a caracterizam, quer pela potencialização dos riscos de natureza física, química ou biológica, presentes no processo de produção, devendo ser objeto de normas técnicas.

A vigilância em saúde do trabalhador distingue-se da vigilância em saúde em geral e de outras disciplinas no campo das relaçōes entre saúde e trabalho por delimitar como seu objeto especifico a investigação e intervenção na relação do processo de trabalho com a saúde.

Introduzir nos serviços municipais de saúde, a intervenção nos ambientes de trabalho não compreende de maneira alguma questōes apenas técnicas.

A relação saúde-trabalho é permeada por conflitos e interesses de diversos atores (trabalhadores, sindicatos, empresários, profissionais de saúde e segurança, população geral). Cabe ao poder público o papel fundamental de mediar negociações com o objetivo de proteger a saúde e segurança dos trabalhadores, buscando a colaboração da sociedade e do empresariado e sindicatos em particular. Mais especificamente, significa buscar negociações entre os sindicatos de trabalhadores, associações de 
portadores de doenças profissionais, entidades patronais, entidades de trabalhadores da saúde etc.

Apesar da iniciativa elogiável de alguns profissionais comprometidos com a saúde do trabalhador, a estratégia institucional adotada pelo Ministério do Trabalho para a fiscalização dos ambientes de trabalho caracteriza-se por atividades em que se destacam intervenções:

- Pontuais e aleatórias - uma vez que atendem apenas às demandas registradas na forma de processo administrativo;

- Unidisciplinares - pois adotam como método de trabalho a fiscalização onde cada profissional (médico, engenheiro e agente de higiene e segurança) efetua inspeções isoladamente;

- Rígidas - pois se limitam ao check-list das normas de segurança e às puniçōes pré-estabelecidas cartorialmente - multa, embargo ou interdição;

- Sujeitas à corrupção - pela atividade isolada do fiscal e pela falta de transparência e controle de sua ação;

- Punitivas - ao se limitarem a aplicar as penalidades previstas na lei não garantem a correção dos problemas identificados, tampouco a mudança da política da Empresa no tocante à segurança e à saúde do trabalhador;

- Restritas - por fiscalizarem o cumprimento da legislação federal Normas Regulamentadoras, Lei 6514/Portaria 3214, ainda que a legislação estadual supere a federal em abrangência e especificidade para os problemas do Estado em questão;

- Limitadas em sua abrangência - ao intervirem em uma única Empresa não oferecem garantias de mudanças em qualquer outra Empresa do mesmo setor de produção;

- Excludentes - pela não participação dos trabalhadores, seja no ato da fiscalização, seja no resultado das inspeções, não estão sujeitas ao Controle Social; 
- Não Evolutivas - por estarem restritas às Normas, são incapazes de lidar com situações não previstas na letra da lei, que poderiam subsidiar o próprio aperfeiçoamento normativo.

A Instrução Normativa de Vigilância em Saúde do Trabalhador no SUS tem a finalidade de definir procedimentos básicos para 0 desenvolvimento dessas ações. Há nesse texto, uma série de recomendações para a implementação da Vigilância dos Ambientes de Trabalho, dentro dos princípios do SUS.

Essa Instrução Normativa calca-se no modelo epidemiológico de pesquisa dos agravos, nos diversos niveis da relação entre o trabalho e a saúde, agregando ao universo da avaliação e análise a capacidade imediata da intervenção sobre os fatores determinantes dos danos à saúde.

No Estado de São Paulo, através da Resolução SS-196, de 29 de dezembro de 1998, foram padronizados Roteiros e Guias de Inspeção em Vigilância Sanitária, no qual se inclui a Ficha Preliminar de Análise de Riscos Ocupacionais, o qual se constitui num importante roteiro para a avaliação de um local de trabalho.

O Ministério Público do Estado de São Paulo também tem um roteiro de inspeção, mais voltado para o enquadramento legal dos problemas de saúde do trabalhador.

Para a inspeção do local de trabalho deve ser elaborado um roteiro que possa ser flexibilizado a depender do objeto da avaliação e da investigação preliminar realizada. Os roteiros citados são recomendados. Os roteiros, após preenchidos, serão transformados em relatórios que servirāo de base para a negociação da intervenção a ser realizada no ambiente de trabalho. 


\section{FINANCIAMENTO DAS AÇÕES DE SAÚDE DO TRABALHADOR NO MUNICÍPIO}

A Lei 8.212/91 regulamenta o Seguro de Acidentes do Trabalho SAT - que se destina ao financiamento da Aposentadoria Especial e dos benefícios previdenciários concedidos em razão do grau de incidência de incapacidade laborativa decorrente dos riscos ambientais do trabalho. De acordo com o grau de risco, poderá ser constituído por $1 \%, 2 \%$ ou $3 \%$ da folha de pagamentos da Empresa, ou seja, sobre o total das remuneraçōes pagas ou creditadas, no decorrer do mês, aos segurados empregados e trabalhadores avulsos.

Portanto, o SAT, a partir da edição desta Lei, deixou de custear as atividades de proteção, promoção, recuperação e reabilitação da saúde dos trabalhadores, passando a fazê-lo apenas quanto aos benefícios previdenciários.

A Portaria Interministerial MPAS/MS no 14, de 13 de fevereiro de 1996 (BRASIL, 1996) resolveu que para co-participar dos gastos do SUS relativos à assistência ao trabalhador, o Ministério da Previdência e Assistência Social transferirá, mensalmente, ao Ministério da Saúde, recursos oriundos da arrecadação do SAT, de acordo com crédito orçamentário devidamente aprovado.

Essa mesma Portaria estabeleceu o inicio do PIAT - Programa Integrado de Assistência ao Acidentado do Trabalho - através da organização da oferta de atendimento hospitalar de urgência e emergência, incluindo internação ao trabalhador acometido de doença profissional ou vítima de acidente do trabalho. Estabeleceu, também, a divulgação aos organismos interessados, à população em geral e, especialmente, às entidades representativas dos trabalhadores e dos empregadores, a lista dos hospitais integrantes do PIAT, definida em cada estado sob a 
responsabilidade do Secretário Estadual e dos Secretários Municipais de Saúde, com a recomendação de que, em caso de acidente do trabalho, estes hospitais sejam procurados preferencialmente.

Essa Portaria estabeleceu ainda, a atribuição de remuneração diferenciada, através de sistemática a ser estabelecida em ato normativo da Secretaria de Assistência à Saúde do MS, aos procedimentos realizados en casos de acidente do trabalho.

Essa Portaria se baseou em documento elaborado pelo Ministério da Saúde (1995) que contabilizou os recursos financeiros gastos com o atendimento de trabalhadores vitimados por acidentes e doenças do trabalho e que propôs que uma parcela dos recursos oriundos da arrecadação do SAT deve ser destinada ao financiamento das açōes relacionadas à saúde dos trabalhadores no âmbito do SUS.

No entanto, a remuneração diferenciada para o atendimento aos casos de acidente do trabalho ainda não está sendo praticada.

A NOST estabelece que "a organização de unidades especializadas de referência em Saúde do Trabalhador, o estímulo à implementação de unidades no Municipio, na região ou em forma de consórcio, e o registro de $100 \%$ dos casos atendidos de acidentes de trabalho e agravos decorrentes do processo de trabalho, comporão o Indice de Valorização de Resultados (IVR), de acordo com os critérios a serem definidos pela Comissão Intergestores Tripartite, e a ser estabelecido em portaria do Ministério da Saúde" .e prossegue: "A implementação do financiamento das ações de saúde do trabalhador consiste na garantia do recebimento dos recursos por meio das fontes de transferências, já constituidas legalmente em cada esfera de governo e na definição de mecanismos que garantam que os recursos provenientes destas fontes sejam aplicados no desenvolvimento das ações de saúde do trabalhador estabelecidas nos planos de saúde." 
No entanto, o Índice de Valorização dos Resultados para o estímulo ao desenvolvimento das açōes de Saúde do Trabalhador não se encontra ainda regulamentado e os Municipios deverão aplicar recursos próprios para a implantação desses programas, registrando os atendimentos realizados pela equipe como atendimentos de Clinica Médica, no SIAJSUS. 


\section{CONTROLE SOCIAL NO PROGRAMA MUNICIPAL DE SAÚDE DO TRABALHADOR}

O envolvimento dos usuários na elaboração, no planejamento, execução e avaliação do programa gera um sentimento de apropriação e favorece a sua manutenção e institucionalização. Outra variável que pode intervir igualmente nesse processo é o nivel de colaboração dos diferentes atores, não necessariamente usuários, implicados no programa.

O projeto do programa em conjunto com a comunidade permite que ela incorpore a ele suas verdadeiras prioridades. Sua intervenção na gestão do projeto dá-lhe uma força singular. Ao sentir-se dona real do projeto, a comunidade traz iniciativas, idéias, preocupa-se com cada detalhe de seu funcionamento. Sua integração ao acompanhamento e à avaliação permite que o projeto tenha um pólo permanente da realidade. Os beneficiados estarão dizendo continuamente em que medida se compõem ou não os objetivos fixados e que correçōes deveriam ser introduzidas.

Para concretizar o Controle Social, no que diz respeito à saúde, o Programa de Saúde do Trabalhador deve ser capaz de ajustar-se, no seu cotidiano, à participação do movimento sindical em todas as esferas de ação, nos seus planejamento, execução e avaliação.

As atividades da Vigilância em Saúde do Trabalhador, sob a ótica do Controle Social, pressupõem, como fundamento, que se ultrapasse a esfera de consulta ao movimento social e realmente o incorpore nas ações por dentro da máquina do Estado.

A NOST recomenda a instituição de Comissão Intersetorial de Saúde do Trabalhador, com a participação de entidades que tenham interfaces com a área de saúde do trabalhador, subordinada ao Conselho Municipal de Saúde, com a finalidade de assessorá-lo na definição das políticas, no 
estabelecimento de prioridades e no acompanhamento e avaliação das ações de saúde do trabalhador.

Também a Instrução Normativa de Vigilância em Saúde do Trabalhador, considera como principio o Controle Social, entendendo-o como a incorporação dos trabalhadores e das suas organizações, principalmente as sindicais, em todas as etapas da vigilância em saúde do trabalhador, compreendendo sua participação na identificação das demandas, no planejamento, no estabelecimento de prioridades e adoção de estratégias, na execução das ações, no seu acompanhamento e avaliação e no controle da aplicação dos recursos.

Mais à frente, a Instrução Normativa prossegue: "Recomenda-se a criação de comissão, na forma colegiada, com a participação de trabalhadores, suas organizaçōes sindicais e instituições públicas com responsabilidades em saúde do trabalhador, vinculada organicamente ao SUS e subordinada aos Conselhos Estaduais e Municipais de Saúde, com a finalidade de assessorá-lo na definição de politicas, no estabelecimento de diretrizes e prioridades, e no acompanhamento e avaliação da execução das ações de saúde do trabalhador. 


\section{GLOSSÁRIO}

AIS - Programa das Ações Integradas de Saúde

CAT - Comunicação de Acidente do Trabalho

CEP - Código de Endereçamento Postal

CGC - Cadastro Geral de Contribuintes

CIPA - Comissão Interna de Prevenção de Acidentes

CLT - Consolidação das Leis do Trabalho

CNPJ - Cadastro Nacional de Pessoas Jurídicas

Conasp - Conselho Consultivo da Administração da Saúde Previdenciária -

CEREST - Centro de Referência Estadual em Saúde do Trabalhador CRST - Centro de Referência em Saúde do Trabalhador

DETRAN - Departamento Estadual de Trânsito

DRT - Delegacia Regional do Trabalho

FAA - Ficha de Atendimento Ambulatorial

IML - Instituto Médico Legal

INAMPS - Instituto Nacional de Assistência Médica da Previdência Social

INSS - Instituto Nacional do Seguro Social

LEM - Laudo de Exame Médico

LOS - Lei Orgânica da Saúde

MPAS - Ministério da Previdência e Assistência Social

MS - Ministério da Saúde 
NOB - Norma Operacional Básica

NOST - Norma Operacional de Saúde do Trabalhador

PIASS - Programa de Interiorização das Ações de Saúde e Saneamento

PIAT - Programa Integrado de Assistência ao Acidentado do Trabalho Prev-Saúde - Programa Nacional de Serviços Básicos de Saúde PST - Programa de Saúde do Trabalhador

RAAT - Relatório de Atendimento de Acidentado do Trabalho

RAIS - Relação Anual de Informações Sociais

REM - Relatório de Exame Médico

SAT - Seguro de Acidentes do Trabalho

SESMT - Serviço Especializado em Segurança e Medicina do

Trabalho

SIAVSU - Sistema de Informações Ambulatoriais do SUS

SIH/SUS - Sistema de Informações Hospitalares do SUS

SINAN - Sistema de Notificação de Agravos Notificáveis

SISCAT - Sistema de Informação para Acidentes e Doenças do Trabalho

SUDS - Sistema Unificado e Descentralizado de Saúde

SUS - Sistema Único de Saúde

VISA - Vigilância Sanitária 